Water Availability and Use Science Program

Prepared in cooperation with the Bureau of Reclamation

\title{
Evaporation from Lake Mead and Lake Mohave, Nevada and Arizona, 2010-2019
}

Open-File Report 2021-1022 
Cover photo: Looking south at Boulder Basin in Lake Mead. Photograph taken by Michael Rosen, April 5, 2015. 


\section{Evaporation from Lake Mead and Lake Mohave, Nevada and Arizona, 2010-2019}

By Katherine J. Earp and Michael T. Moreo

Water Availability and Use Science Program

Prepared in cooperation with the Bureau of Reclamation

Open-File Report 2021-1022 


\section{U.S. Geological Survey, Reston, Virginia: 2021}

For more information on the USGS - the Federal source for science about the Earth, its natural and living resources, natural hazards, and the environment—visit https://www.usgs.gov or call 1-888-ASK-USGS.

For an overview of USGS information products, including maps, imagery, and publications, visit https://store.usgs.gov/.

Any use of trade, firm, or product names is for descriptive purposes only and does not imply endorsement by the U.S. Government.

Although this information product, for the most part, is in the public domain, it also may contain copyrighted materials as noted in the text. Permission to reproduce copyrighted items must be secured from the copyright owner.

Suggested citation:

Earp, K.J., and Moreo, M.T., 2021, Evaporation from Lake Mead and Lake Mohave, Nevada and Arizona, 2010-2019: U.S. Geological Survey Open-File Report 2021-1022, 36 p., https://doi.org/10.3133/ofr20211022.

ISSN 2331-1258 (online) 


\section{Contents}

Abstract

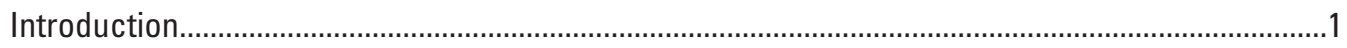

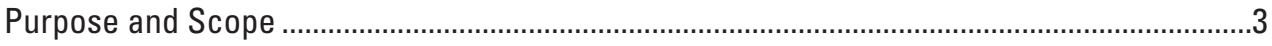

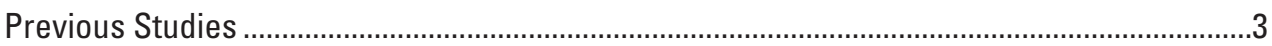

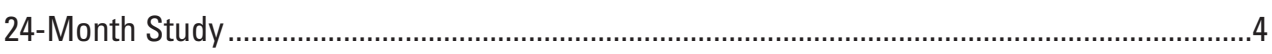

Description of Study Area ..........................................................................................

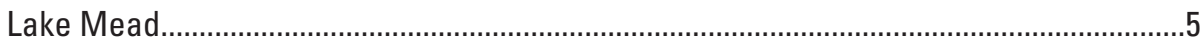

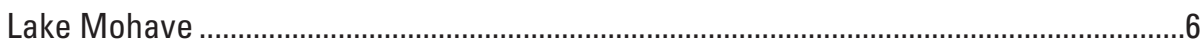

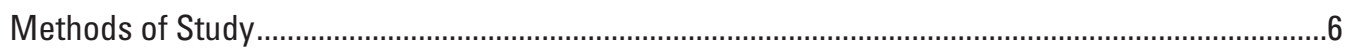

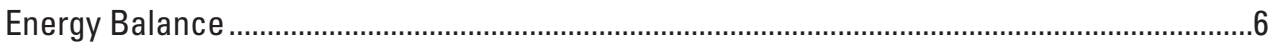

Eddy Covariance Turbulent Flux Measurements......................................................................

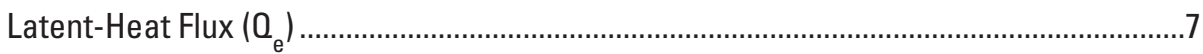

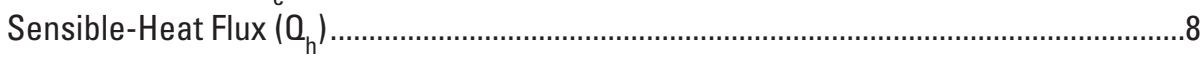

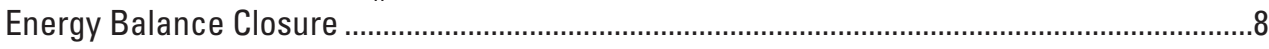

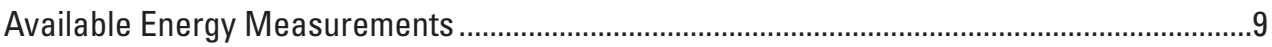

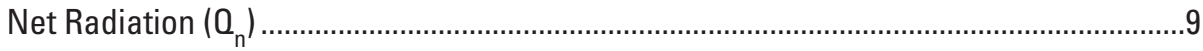

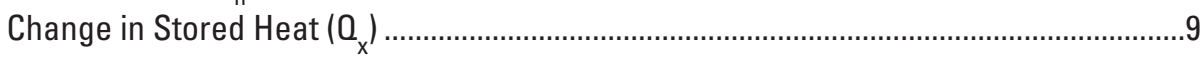

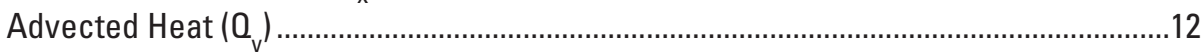

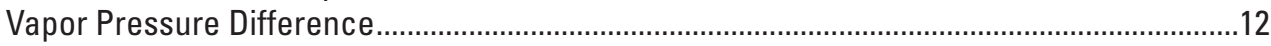

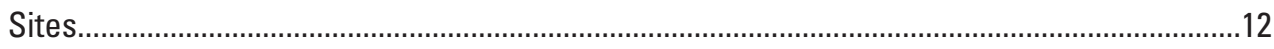

Instrumentation for Turbulent Flux Measurements....................................................13

Instrumentation for Available Energy Measurements.................................................14

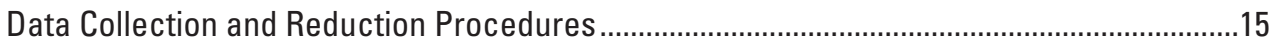

Gap Filling Missing or Bad Turbulent-Flux Data ...........................................................16

Evaporation from Lake Mead and Lake Mohave.........................................................................

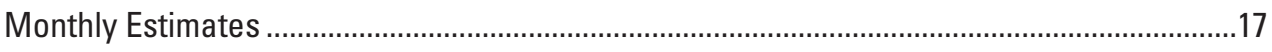

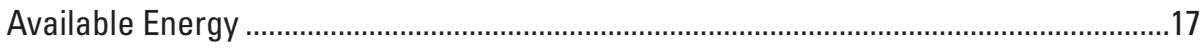

Water-Temperature Profiles ............................................................................19

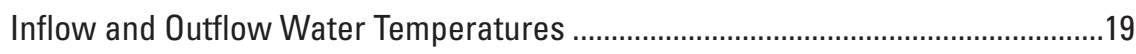

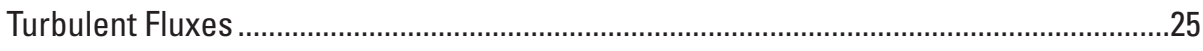

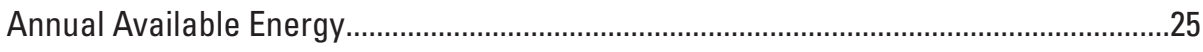

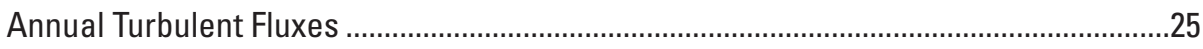

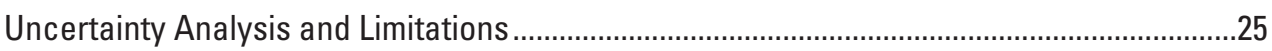

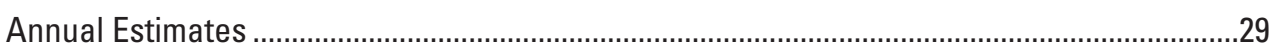

Comparison to Existing Rate Coefficients.........................................................................

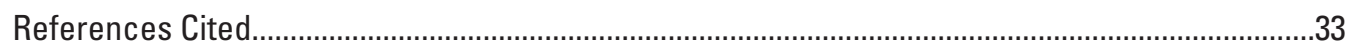




\section{Figures}

1. Map showing overview of Lake Mead and Lake Mohave in Lake Mead National Recreation Area in Nevada and Arizona .

2. Diagram showing major energy-budget components diagram

3. Map showing overview showing eddy covariance and floating platform sites in Boulder Basin, Lake Mead, Nevada and Arizona .....

4. Map showing overview showing eddy covariance and floating platform sites, Lake Mohave, Nevada and Arizona.

5. Photograph showing eddy covariance station showing turbulent flux sensors position, Lake Mead, Nevada and Arizona.

6. Photograph showing floating platform showing available energy sensor positioning, Lake Mohave, Nevada and Arizona.

7. Graphs showing monthly minimum, mean, and maximum evaporation at Lake Mead, Nevada and Arizona, March 2010 through April 2019 and Lake Mohave, Nevada and Arizona, May 2013 through April 2019; and monthly mean evaporation at Lake Mead and Lake Mohave, Nevada and Arizona, May 2013 through April 2019

8. Graphs showing mean monthly, available energy, net radiation, change in stored heat, and advected heat, Lake Mead and Lake Mohave, Nevada and Arizona, May 2013 through April 2019

9. Graph showing mean monthly inflow and outflow water temperatures at Lake Mead and Lake Mohave, Nevada and Arizona, May 2013 through April 2019.

10. Graphs showing mean water-temperature profiles by depth at Lake Mead, Nevada and Arizona, March 2010 through October 2016; and at Lake Mohave, Nevada and Arizona, May 2013 through October 2016

11. Graph showing monthly mean inflow and outflow water temperatures at Lake Mead, Nevada and Arizona, March 2010 through April 2019, and Lake Mohave, Nevada and Arizona, May 2013 through April 2019

12. Graphs showing mean monthly turbulent flux, latent-heat flux, sensible-heat flux, and Bowen ratio, Lake Mead and Lake Mohave, Nevada and Arizona, May 2013 through April 2019

13. Graphs showing annual available energy, net radiation, change in stored heat, and advected heat, Lake Mead and Lake Mohave, Nevada and Arizona, May 2010 through April 2019

14. Graphs showing annual turbulent flux, latent-heat flux, sensible-heat flux, and energy balance ratio, Lake Mead and Lake Mohave, Nevada and Arizona, May 2010 through April 2019

15. Graph showing mean monthly vapor pressure difference at Lake Mead and Lake Mohave, Nevada and Arizona, May 2013 through April 2019

16. Graphs showing probable minimum, most probable, and probable maximum annual evaporation at Lake Mead and Lake Mohave; and most probable annual evaporation at Lake Mead and Lake Mohave, Nevada and Arizona, May 2010 through April 2019

17. Graphs showing Lake Mead and Lake Mohave, Nevada and Arizona, mean monthly evaporation estimates for this study compared to 24-month study evaporation coefficients, March 2013 through April 2019 


\section{Tables}

1. Monthly evaporation coefficients used in the Bureau of Reclamation's 24-Month Study on projected hydrologic conditions and water use of Lake Mead and Lake Mohave, Nevada and Arizona ..................................................................5

2. Location and general description of measurement sites, Lake Mead and Lake Mohave, Nevada and Arizona ......................................................................................13

3. Turbulent flux and available energy data gaps at Lake Mead and Lake Mohave, Nevada and Arizona, 2015-18.......................................................................................16

4. Annual energy balance and summary statistics, Lake Mead, Nevada and Arizona, January 2011 through December 2018

5. Annual energy balance and summary statistics, Lake Mohave, Nevada and Arizona, January 2014 through December 2018.

6. Monthly evaporation and summary statistics, Lake Mead, Nevada and Arizona, March 2010 through April 2019.

7. Monthly evaporation and summary statistics, Lake Mohave, Nevada and Arizona, May 2013 through April 2019.

8. Annual evaporation and summary statistics, Lake Mead, Nevada and Arizona, January 2011 through December 2018.

9. Annual evaporation and summary statistics, Lake Mohave, Nevada and Arizona, January 2014 through December 2018.

\section{Conversion Factors}

International System of Units to U.S. customary units

\begin{tabular}{|c|c|c|}
\hline Multiply & By & To obtain \\
\hline \multicolumn{3}{|c|}{ Length } \\
\hline centimeter $(\mathrm{cm})$ & 0.3937 & inch (in.) \\
\hline millimeter (mm) & 0.03937 & inch (in.) \\
\hline meter $(\mathrm{m})$ & 3.281 & foot $(\mathrm{ft})$ \\
\hline kilometer $(\mathrm{km})$ & 0.6214 & mile (mi) \\
\hline meter $(\mathrm{m})$ & 1.094 & yard $(\mathrm{yd})$ \\
\hline \multicolumn{3}{|c|}{ Area } \\
\hline square meter $\left(\mathrm{m}^{2}\right)$ & 0.0002471 & acre \\
\hline hectare (ha) & 2.471 & acre \\
\hline square kilometer $\left(\mathrm{km}^{2}\right)$ & 247.1 & acre \\
\hline square meter $\left(\mathrm{m}^{2}\right)$ & 10.76 & square foot $\left(\mathrm{ft}^{2}\right)$ \\
\hline hectare (ha) & 0.003861 & square mile $\left(\mathrm{mi}^{2}\right)$ \\
\hline square kilometer $\left(\mathrm{km}^{2}\right)$ & 0.3861 & square mile $\left(\mathrm{mi}^{2}\right)$ \\
\hline \multicolumn{3}{|c|}{ Volume } \\
\hline cubic meter $\left(\mathrm{m}^{3}\right)$ & 0.0002642 & million gallons (Mgal) \\
\hline cubic centimeter $\left(\mathrm{cm}^{3}\right)$ & 0.06102 & cubic inch $\left(\mathrm{in}^{3}\right)$ \\
\hline cubic meter $\left(\mathrm{m}^{3}\right)$ & 35.31 & cubic foot $\left(\mathrm{ft}^{3}\right)$ \\
\hline cubic meter $\left(\mathrm{m}^{3}\right)$ & 0.0008107 & acre-foot (acre-ft) \\
\hline million cubic meter $\left(\mathrm{Mm}^{3}\right)$ & 0.8107132 & kilo acre-foot (Kaf) \\
\hline
\end{tabular}




\begin{tabular}{|c|c|c|}
\hline Multiply & By & To obtain \\
\hline \multicolumn{3}{|c|}{ Flow rate } \\
\hline cubic meter per second $\left(\mathrm{m}^{3} / \mathrm{s}\right)$ & 70.07 & acre-foot per day (acre-ft/d) \\
\hline cubic meter per year $\left(\mathrm{m}^{3} / \mathrm{yr}\right)$ & 0.000811 & acre-foot per year (acre-ft/yr) \\
\hline meter per second (m/s) & 3.281 & foot per second (ft/s) \\
\hline cubic meter per second $\left(\mathrm{m}^{3} / \mathrm{s}\right)$ & 35.31 & cubic foot per second $\left(\mathrm{ft}^{3} / \mathrm{s}\right)$ \\
\hline cubic meter per day $\left(\mathrm{m}^{3} / \mathrm{d}\right)$ & 264.2 & gallon per day (gal/d) \\
\hline cubic meter per second $\left(\mathrm{m}^{3} / \mathrm{s}\right)$ & 22.83 & million gallons per day (Mgal/d) \\
\hline millimeter per year $(\mathrm{mm} / \mathrm{yr})$ & 0.03937 & inch per year (in/yr) \\
\hline kilometer per hour $(\mathrm{km} / \mathrm{h})$ & 0.6214 & mile per hour (mi/h) \\
\hline \multicolumn{3}{|c|}{ Mass } \\
\hline gram (g) & 0.03527 & ounce, avoirdupois (oz) \\
\hline kilogram (kg) & 2.205 & pound avoirdupois (lb) \\
\hline \multicolumn{3}{|c|}{ Pressure } \\
\hline kilopascal (kPa) & 0.009869 & atmosphere, standard (atm) \\
\hline kilopascal (kPa) & 0.01 & bar \\
\hline kilopascal (kPa) & 0.1450 & pound per square inch $\left(\mathrm{lb} / \mathrm{ft}^{2}\right)$ \\
\hline \multicolumn{3}{|c|}{ Density } \\
\hline kilogram per cubic meter $\left(\mathrm{kg} / \mathrm{m}^{3}\right)$ & 0.06242 & pound per cubic foot $\left(\mathrm{lb} / \mathrm{ft}^{3}\right)$ \\
\hline gram per cubic centimeter $\left(\mathrm{g} / \mathrm{cm}^{3}\right)$ & 62.4220 & pound per cubic foot $\left(\mathrm{lb} / \mathrm{ft}^{3}\right)$ \\
\hline \multicolumn{3}{|c|}{ Energy } \\
\hline joule $(\mathrm{J})$ & 0.0000002 & kilowatthour (kWh) \\
\hline joule per cubic meter $\left(\mathrm{J} / \mathrm{m}^{3}\right)$ & 0.00000738 & watthour per cubic foot $\left(\mathrm{Wh} / \mathrm{ft}^{3}\right)$ \\
\hline watt per square meter $\left(\mathrm{W} / \mathrm{m}^{2}\right)$ & 0.0222 & $\begin{array}{l}\text { calorie per second per square foot } \\
\left(\mathrm{cal} / \mathrm{s} / \mathrm{ft}^{2}\right)\end{array}$ \\
\hline \multicolumn{3}{|c|}{ Frequency } \\
\hline hertz $(\mathrm{Hz})$ & 1 & cycle per second \\
\hline
\end{tabular}

Temperature in degrees Celsius $\left({ }^{\circ} \mathrm{C}\right)$ may be converted to degrees Fahrenheit $\left({ }^{\circ} \mathrm{F}\right)$ as follows: ${ }^{\circ} \mathrm{F}$ $=\left(1.8 \times{ }^{\circ} \mathrm{C}\right)+32$.

\section{Datum}

Vertical coordinate information is referenced to the North American Vertical Datum of 1988 (NAVD 88).

Horizontal coordinate information is referenced to the North American Datum of 1983 (NAD 83).

Altitude, as used in this report, refers to distance above the vertical datum.

Lake Mead elevation, as used in this report, is referenced to the U.S. Geological Survey datum, adjustment of 1912, locally known as "Power House Datum." 


\section{Abbreviations}

$\begin{array}{ll}\text { 24MS } & \text { 24-Month Study } \\ \text { AOP } & \text { Annual Operating Plan } \\ \text { BREB } & \text { Bowen ratio energy budget } \\ \text { CSAT3 } & \text { Sonic anemometer } \\ \text { EBR } & \text { Energy balance ratio } \\ \text { EC } & \text { Eddy covariance } \\ \text { KH2O } & \text { Krypton hygrometer } \\ \text { LMNRA } & \text { Lake Mead National Recreation Area } \\ \text { MDV } & \text { Mean diurnal variation } \\ a_{e} & \text { Latent-heat flux } \\ a_{h} & \text { Sensible-heat flux } \\ a_{n} & \text { Net radiation } \\ a_{s} & \text { Solar radiation } \\ a_{v} & \text { Advected heat } \\ a_{x} & \text { Change in stored heat } \\ \text { Reclamation } & \text { Bureau of Reclamation } \\ \text { RM } & \text { River mile } \\ \text { SNWP } & \text { Southern Nevada Water Project } \\ \text { USGS } & \text { U.S. Geological Survey } \\ \end{array}$





\title{
Evaporation from Lake Mead and Lake Mohave, Nevada and Arizona, 2010-2019
}

\author{
By Katherine J. Earp and Michael T. Moreo
}

\section{Abstract}

Evaporation-rate estimates at Lake Mead and Lake Mohave, Nevada and Arizona, were based on eddy covariance and available energy measurements from March 2010 through April 2019 at Lake Mead and May 2013 through April 2019 at Lake Mohave. The continuous data needed to compute monthly evaporation were collected from floating-platform and land-based measurement stations located at each reservoir. Collected data include latent- and sensible-heat fluxes, net radiation, air temperature, wind speed, humidity, and water-temperature profiles. Data collection, analysis methods, and monthly evaporation results for Lake Mead through February 2012 were documented in a U.S. Geological Survey (USGS) Scientific-Investigations Report, 2013-5229. Monthly evaporation and associated datasets for both reservoirs through April 2015 were published in a USGS Data Release (https://doi.org/10.5066/F79C6VG3). Average annual evaporation at Lake Mead was 1,896 millimeters (mm), which is a 10 percent difference from the $1,718 \mathrm{~mm}$ average annual evaporation at Lake Mohave; this was primarily due to differences in available energy. Average annual available energy at Lake Mead was 139 watts per square meter $\left(\mathrm{W} / \mathrm{m}^{2}\right)$, which is an 18 percent difference from the $116 \mathrm{~W} / \mathrm{m}^{2}$ average annual available energy at Lake Mohave. Differences in available energy are driven by differences in advected heat between Lake Mead and Lake Mohave; advected heat at Lake Mohave is lower due to colder inflows and warmer outflows. Lake Mead monthly evaporation estimates for this study compare reasonably well to the Bureau of Reclamation's 24-Month Study (24MS) evaporation coefficients, which are based on pioneering studies from the 1950s. Temporal trends in this study indicate that the effects of heat storage at Lake Mead were underestimated in the $24 \mathrm{MS}$, particularly during the fall months when energy was released from the lake. Mean monthly evaporation rates at Lake Mead were greater than Lake Mohave from June through November during the study period. The seasonal pattern of evaporation at Lake Mohave in this study indicates that the effects of available energy were underestimated in the 24MS coefficients for this reservoir, and that evaporation was substantially overestimated from spring through summer during the study period of 2013 through 2019.

\section{Introduction}

Lake Mead is part of a system of dams and reservoirs that control the Colorado River and enable its efficient use (fig. 1). Water demand has steadily increased since the implementation of the Colorado River Compact of 1922 as the upper- and lower-basin states have built the infrastructure needed to capture their full apportionment. From 2000 to 2010, the stage of Lake Mead fell approximately 40 meters (m; 131 feet, ft), raising concerns among water managers about future water shortages. Future water shortages in the Colorado River system could result from decreased runoff caused by continuing shortterm drought and long-term climate change. Accordingly, imbalances between the water supply and demand may continue. Increasingly scarce water resources have underscored a need to improve water accounting and projection accuracy.

The Bureau of Reclamation (Reclamation) Lower Colorado Region is responsible for delivering water from the lower Colorado River to Arizona, California, Nevada, and Mexico. These responsibilities include (1) accounting for diversions, consumptive use, and return flows; and (2) projecting Lower Basin water availability. Reclamation operates a model called the 24-Month Study (24MS) that projects future Colorado River reservoir volumes and potential dam operations based on hydrologic conditions at the time of this study, projected hydrologic conditions, and operational policies and guidelines (https://www.usbr.gov/lc/region/g4000/24mo.pdf). Each month, the $24 \mathrm{MS}$ simulates water budgets and projects future reservoir conditions and potential dam operations for the next 24-month period. Increasing the accuracy of the $24 \mathrm{MS}$ model and improving projected hydrologic conditions are high priorities for Reclamation.

In cooperation with Reclamation, the U.S. Geological Survey (USGS) conducted a study to improve 24MS model projections by improving monthly estimates of evaporation from Lake Mead and Lake Mohave. Reservoir evaporation is a water-budget term used in the model that is based on poorly documented modifications to original USGS estimates (Harbeck and others, 1958). In this study, the continuous data needed to compute monthly evaporation were collected from floating-platform and land-based measurement stations located at each reservoir. Collected data include latent- and sensibleheat fluxes $\left(\mathrm{Q}_{\mathrm{e}}\right.$ and $\left.\mathrm{Q}_{\mathrm{h}}\right)$, net radiation $\left(\mathrm{Q}_{\mathrm{n}}\right)$, air temperature, 


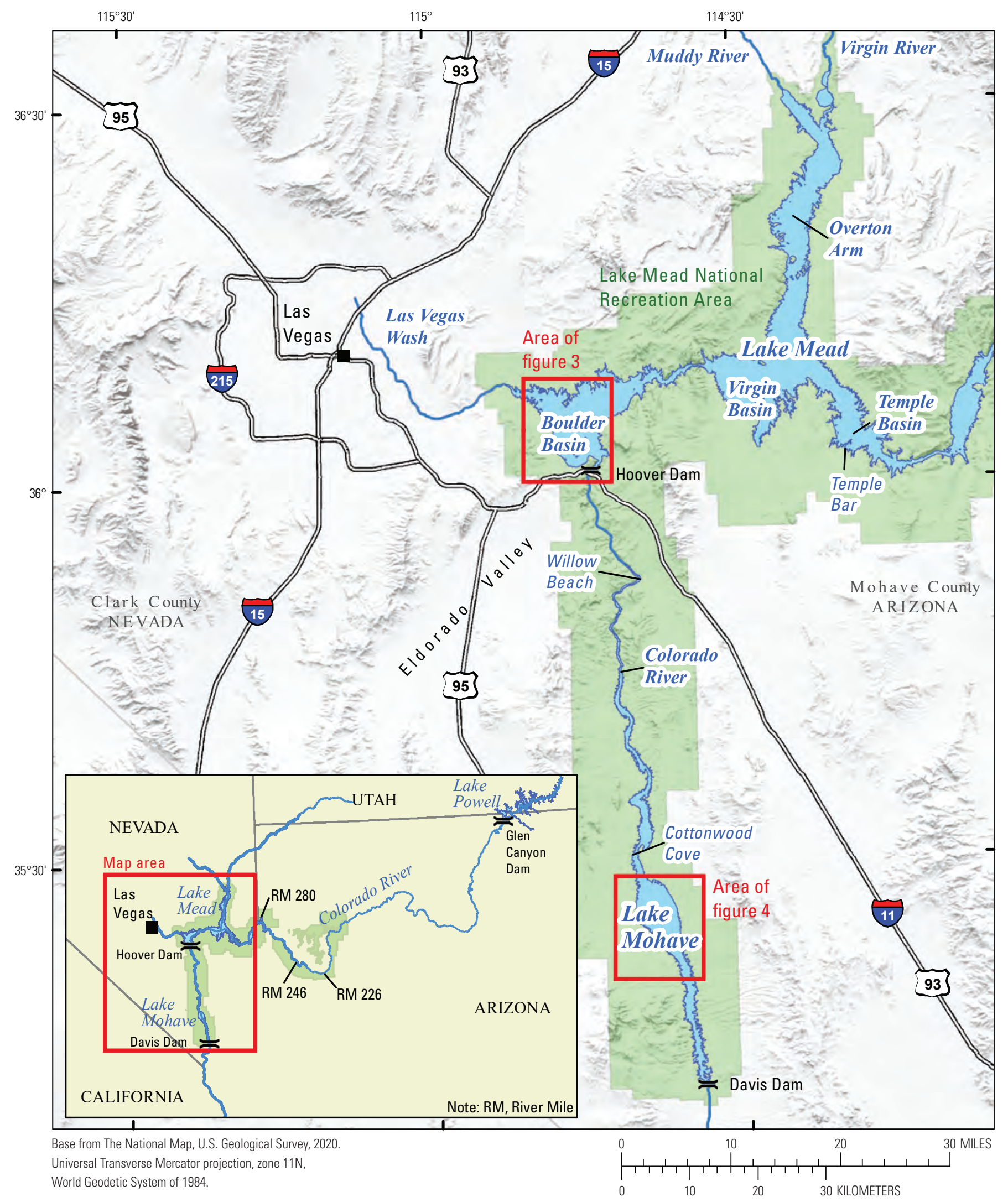

Figure 1. Overview of Lake Mead and Lake Mohave in Lake Mead National Recreation Area in Nevada and Arizona. 
wind speed, humidity, and water-temperature profiles. Measurements began in March 2010 at Lake Mead and May 2013 at Lake Mohave and ended in May 2019 for both lakes. There were three prior publications released for this study: (1) data collection, analysis methods, and monthly evaporation results for Lake Mead through February 2012 were documented in a USGS Scientific-Investigations Report (Moreo and Swancar, 2013; https://pubs.usgs.gov/sir/2013/5229/pdf/ sir2013-5229.pdf); (2) monthly evaporation and associated datasets for both reservoirs through April 2015 were published in a USGS Data Release (Moreo, 2015; https://www.scienc ebase.gov/catalog/item/55f6fba8e4b0477df11bff2b); and (3) meteorological data from both lakes following the removal of the floating platforms in September 2016 at Lake Mohave and in April 2017 at Lake Mead were published in a USGS Data Release (Moreo, 2018; https://www.sciencebase.gov/catalog/ item $/ 5 \mathrm{a} 74 \mathrm{e} 8 \mathrm{c} 1 \mathrm{e} 4 \mathrm{~b} 00 \mathrm{f} 54 \mathrm{eb} 1 \mathrm{c} 82 \mathrm{df})$. Some of the text in this report is drawn from Moreo and Swancar (2013).

\section{Purpose and Scope}

The purpose of this report is to present updated monthly evaporation estimates for Lake Mead and Lake Mohave using the eddy covariance (EC) and energy balance methods. This report enhances the 2013 Moreo and Swancar report by providing additional years of data. Monthly evaporation-rate estimates are based on EC and available energy measurements from March 2010 through April 2019 at Lake Mead and May 2013 through April 2019 at Lake Mohave. The results are expected to improve water-budget and projection accuracy of Reclamation's 24MS model (Moreo and Swancar, 2013).

\section{Previous Studies}

The earliest attempt to estimate evaporation from Lake Mead based on meteorological and limnological data was by Anderson and Pritchard (1951). Their work was part of a series of comprehensive surveys conducted by the USGS, Reclamation, the U.S. Navy Electronics Laboratory, and others to evaluate sedimentation and salinity in 1948-49 (Smith and others, 1960). Lake temperature profiles were measured monthly at more than 60 locations. The Bowen ratio energy budget (BREB) method was used to estimate an annual evaporation rate of 1,626 millimeters (mm; 64 inches, in.). Their study highlighted the need to more fully develop the BREB method at a lake where evaporation was known. These same agencies then participated in a landmark study of lake evaporation at Lake Hefner, Oklahoma in 1950-51 (U.S. Geological Survey, 1954). This location was chosen because, in contrast to Lake Mead, the water budget could be determined with sufficient accuracy (plus or minus 5 percent) to serve as a control for testing evaporation methods including energy budget and mass transfer. The study group subsequently moved back to Lake Mead in 1952-53 to conduct further research into methods and the equipment needed to measure evaporation accurately (Harbeck and others, 1958). The BREB method was chosen as the control to test mass-transfer equations, even though the method was not expected to be as accurate as the water-budget control at Lake Hefner. The annual evaporation estimates for the BREB and mass-transfer methods were in such close agreement, partly because these methods were not completely independent as applied, that the investigators combined them for an average annual evaporation rate of 2,172 mm (86 in.) for Lake Mead (Harbeck and others, 1958). The resulting average evaporation volume of 1,079 million cubic meters $\left(\mathrm{Mm}^{3}\right)$; 875 kilo acre feet, Kaf) is nearly three times Nevada's annual allocation from the Colorado River of $370 \mathrm{Mm}^{3}$ (300 Kaf). As a more practical way to estimate monthly evaporation than these large-scale study efforts, a mass-transfer equation was devised whereby monthly evaporation could be estimated with a combination of variables measured at Lake Mead and at the Las Vegas airport (Harbeck and others, 1958). This equation was used by Reclamation to estimate evaporation until 1994. The mean annual evaporation rate for the period 1953-94 was 1,930 $\mathrm{mm}$ (76 in.), but the mean for 1953-73 was 2,032 $\mathrm{mm}$ (80 in.), and the mean for 1974-94 was 1,829 mm (72 in.; Westenburg and others, 2006). The lower annual evaporation rates during the latter period also were more variable, which may have resulted either from a series of programmatic modifications or faulty equipment. Westenburg and others (2006) established four floating platforms in different basins in Lake Mead for varying lengths of time between 1997 and 1999. Using the BREB method, they estimated an annual evaporation rate of 2,286 $\mathrm{mm}$ (90 in.).

Harbeck and others (1958) concluded that, for cost effectiveness, operational estimates of evaporation from Lake Mead are obtainable with data collected in Boulder Basin (fig. 1). The areal variation in water temperature is minimal based on observations of water-temperature profiles in Boulder Basin, Virgin Basin, Overton Arm, and Temple Bar (fig. 1; Harbeck and others, 1958). Similarly, Anderson and Pritchard (1951) concluded that a single water-temperature profile measurement in Boulder Basin reasonably represents the entire lake. These conclusions are supported by analyses of water-temperature profiles contained within this report and additional data reported in Veley and Moran (2012). Based on a less than 2-percent difference in net incoming radiation from the four stations in the Lake Mead area used by Harbeck and others (1958), there is "no basis to conclude that there is a significant areal variation in radiation." A maximum deviation in the Bowen ratio of 0.079 between these four sites indicated a maximum variation in evaporation of 8 percent.

Westenburg and others (2006) evaluated the spatial variation in monthly evaporation at three open-water sites and one partially wind-sheltered site using the BREB method and concluded that the spatial variation in evaporation was minimal for open-water areas of Lake Mead. The spatial variations in evaporation reported by both Westenburg and others (2006) and Harbeck and others (1958) are within the 5-10 percent uncertainty range for the EC method reported by Foken (2008, p. 122). 
Anderson and Pritchard (1951) determined that a single temperature profile was representative of all of Lake Mead for the purpose of quantifying change in stored heat $\left(Q_{x}\right)$ based on 12 surveys over a year at 60 locations distributed throughout the lake. They found that differences between temperature profiles in shallow and deep parts of the lake were not significant and that "energy storage for any standard layer and the monthly change in this storage are essentially uniform regardless of the depth of the water." Similarly, a Wilcoxon signed-rank statistical test of monthly $\mathrm{Q}_{\mathrm{x}}$ was calculated, using temperature data from floating platforms at Sentinel Island, Temple Basin, and Virgin Basin (Veley and Moran, 2012), and found no significant difference between the median monthly $Q_{x}$ for paired values from any two of these locations $(p=0.64$ to 0.93 ).

Moreo and Swancar (2013) measured evaporation from Lake Mead using the EC and BREB methods for the 2-year period beginning in March 2010. When corrected for energy imbalances, annual EC evaporation was 2,070 and 1,880 $\mathrm{mm}$ (81.5 and $74.0 \mathrm{in}$.) for 2010 and 2011, within the range of previous estimates. There was a 9-percent decrease in the evaporation rate and a 10-percent increase in the lake surface area during the second year of the study compared to the first. These offsetting factors resulted in a nearly identical 720 million cubic meters $\left(\mathrm{m}^{3} ; 584,000\right.$ acre-feet, acre-ft) evaporation volume for both years. Monthly evaporation rates were best correlated with wind speed, vapor pressure difference, and atmospheric stability. Differences between monthly mean evaporation and mean monthly evaporation were as much as 20 percent. Net radiation provided most of the energy available for evaporative processes; however, advected heat $\left(\mathrm{Q}_{\mathrm{v}}\right)$ from the Colorado River was an important energy source during the second year of the study (Moreo and Swancar, 2013). Peak evaporation lagged peak $Q_{n}$ by 2 months because a greater proportion of the $Q_{n}$ that reaches the lake goes to heating up the water column during the spring and summer months. As most of this stored energy is released in the later summer and fall months, higher evaporation rates are sustained during fall months even though $\mathrm{Q}_{\mathrm{n}}$ declines. The release of stored heat also fueled nighttime evaporation, which accounted for 37 percent of total evaporation. The annual energy balance ratio (EBR) was 0.90 on average and varied only 0.01 between the 2 years, thus implying that 90 percent of estimated available energy was accounted for by turbulent energy measured using the EC method. More than 90 percent of the turbulent-flux source area represented the open-water surface, and 94 percent of 30-minute turbulent-flux measurements originated from wind directions where the fetch ranged from 2,000 to 16,000 m. Evaporation uncertainties were estimated to be $5-7$ percent.

Moreo and Swancar (2013) also employed the BREB method to measure evaporation from Lake Mead primarily as a validation of EC evaporation measurements at annual timescales. There was good agreement between annual corrected EC and BREB evaporation estimates, providing strong validation of these two largely independent methods. Annual BREB evaporation was 6 and 8 percent greater than EC evaporation for the 2 study years, and both methods indicated that there was a similar decrease in evaporation from the first to the second year. Both methods produced negative $\mathrm{Q}_{h}$ during the same months, and there was a strong correlation between monthly Bowen ratios $\left(R^{2}=0.94\right)$. The correlation between monthly evaporation rates $\left(R^{2}=0.65\right)$, however, was not as strong. Monthly differences in evaporation were attributed primarily to heat storage estimate uncertainty.

\section{4-Month Study}

The 24MS projects monthly hydrologic conditions and operations for Colorado River System reservoirs for the next 2 years. The 24MS is pursuant to the December 2007 Record of Decision on Colorado River Interim Guidelines for Lower Basin Shortages and the Coordinated Operations of Lake Powell and Lake Mead (https://www.usbr.gov/lc/ region/programs/strategies/RecordofDecision.pdf; Bureau of Reclamation, 2007) and is used to develop the Annual Operating Plan (AOP). The AOP is the cooperative working document among Colorado River users that contains the plan of dam and reservoir operations for this year. The 24MS computer model projects future reservoir conditions and potential dam operations for the system of reservoirs given existing reservoir conditions, inflow forecasts and projections, and a variety of operational policies and guidelines.

Monthly evaporation from Lake Mead is a water-budget term used in the model that is based on poorly documented modifications to early estimates of lake evaporation (Harbeck and others, 1958). Evaporation estimates in the 24MS are developed by applying monthly evaporation coefficients to monthly lake volumes. The $24 \mathrm{MS}$ evaporation coefficients change month to month to reflect seasonal variation but do not change on an annual basis (table 1). Evaporation estimates in this study represent monthly evaporation for each year of the period of record, 2010-19 for Lake Mead and 2013-19 for Lake Mohave and can be used to refine the 24MS model for future evaporation projections.

\section{Description of Study Area}

The Colorado River runs nearly 1,450 miles (mi) from its headwaters in Colorado and Wyoming to a historical terminus in the Gulf of California. The Colorado River Basin is over 637,000 square kilometers $\left(\mathrm{km}^{2} ; 246,000\right.$ square miles, $\mathrm{mi}^{2}$ ) and includes parts of seven states in the United States-Wyoming, Colorado, Utah, New Mexico, Arizona, Nevada, and California; and two Mexican states, Sonora and Baja California. Several dams impound and control the river, with the two largest being Glen Canyon Dam (forming Lake Powell) and Hoover Dam (forming Lake Mead; fig. 1). The Colorado River is unregulated between Lake Powell and Lake Mead, with most of that distance occurring through the Grand Canyon. Downstream of Lake Mead, a series of reservoirs 
Table 1. Monthly evaporation coefficients used in the Bureau of Reclamation's 24-Month Study on projected hydrologic conditions and water use of Lake Mead and Lake Mohave, Nevada and Arizona.

[ft, foot]

\begin{tabular}{ccc}
\hline Months & Lake Mead $(\mathbf{f t})$ & Lake Mohave $(\mathbf{f t})$ \\
\hline January & 0.36 & 0.36 \\
February & 0.33 & 0.36 \\
March & 0.37 & 0.48 \\
April & 0.46 & 0.61 \\
May & 0.53 & 0.81 \\
June & 0.64 & 0.93 \\
July & 0.80 & 0.93 \\
August & 0.85 & 0.84 \\
September & 0.70 & 0.68 \\
October & 0.51 & 0.56 \\
November & 0.51 & 0.40 \\
December & 0.44 & 0.35 \\
\hline
\end{tabular}

were built to further regulate the river for hydropower and delivery to downstream users, including Lake Mohave (Davis Dam), and Lake Havasu (Parker Dam; Lake Havasu is outside of the Lake Mead Recreation Area and is not included in fig. 1).

The Lake Mead National Recreation Area (LMNRA) consists of Lake Mead and Lake Mohave (fig. 1). The climate in the LMNRA is hot, arid, and windy. This warm, arid environment is conducive to high rates of evaporation. Sparsely vegetated, gentle to moderately sloping alluvial fans and steep, barren, rocky cliffs surround Lake Mead. Generally, the adjacent hills rise to low or moderate height above the lake surface. Lake Mohave is surrounded by sparsely vegetated, steep, and narrow canyon walls, and adjacent hills rise to low or moderate height above the lake surface. Both lakes are exposed to winds from the southwest to southeast in the summer and west/northwest winds during the winter (U.S. Department of Commerce, 1953).

There are four historical National Weather Service cooperator sites (https://www.nws.noaa.gov/om/coop/; http ://www.wrcc.dri.edu/summary/Climsmnv.html) with longer periods of record in the area-Callville Bay $(7 \mathrm{~km}$ northeast of Lake Mead EC2; period of record 1989-2011; http://www.wrc c.dri.edu/cgi-bin/cliMAIN.pl?nv1371), Willow Beach (27 $\mathrm{km}$ south-southeast of Lake Mead EC2 and 57 miles north of Lake Mohave EC1; period of record 1967-2008; http ://www.wrcc.dri.edu/cgi-bin/cliMAIN.pl?az9376), Temple Bar (40 km west of Lake Mead EC2; period of record 1987-2009; http://www.wrcc.dri.edu/cgi-bin/cliMAIN.pl?az8516), and Laughlin (22 miles south of Lake Mohave EC1; period of record 1988-2016; https://wrcc.dri.edu/cgi-bin/cliMAIN.pl? nv4480). There is little variation between these sites in terms of temperature and precipitation amounts. The average of the mean daily maximum temperature for the sites is about 43 degrees Celsius $\left({ }^{\circ} \mathrm{C} ; 110\right.$ degrees Fahrenheit, $\left.{ }^{\circ} \mathrm{F}\right)$ in July and $17{ }^{\circ} \mathrm{C}\left(62^{\circ} \mathrm{F}\right)$ in December, and the average of the mean daily minimum temperature for the sites is about $27^{\circ} \mathrm{C}(80$ $\left.{ }^{\circ} \mathrm{F}\right)$ in July and $4{ }^{\circ} \mathrm{C}\left(39^{\circ} \mathrm{F}\right)$ in December. Period of record annual precipitation was 13.87 centimeters (cm; 5.46 in.) at Callville Bay, $14.12 \mathrm{~cm}$ (5.56 in.) at Willow Beach, $14.27 \mathrm{~cm}$ (5.62 in.) at Temple Bar, and $13.66 \mathrm{~cm}$ (5.38 in) at Laughlin. From January 2014 to December 2018, the annual mean wind speed measured at the Lake Mead EC station was 4.4 meters per second $(\mathrm{m} / \mathrm{s} ; 9.8 \mathrm{mi} / \mathrm{hr})$ and was $4.1 \mathrm{~m} / \mathrm{s}(9.2 \mathrm{mi} / \mathrm{hr})$ at the Lake Mohave EC station. These measured wind speeds are similar to the mean annual wind speed of $3.9 \mathrm{~m} / \mathrm{s}$ recorded at the Las Vegas airport from 1984 to 2010 (National Weather Service, 2013).

\section{Lake Mead}

Lake Mead is the largest reservoir by volume in the nation, and provides drinking water, irrigation, and hydropower to more than 25 million people in three states (Nevada, California, and Arizona; Holdren and Turner, 2010; h ttps://www.usbr.gov/projects/index.php?id=540). Lake Mead was formed following the 1935 completion of Hoover Dam and it took 6 years for the Colorado River to fill the reservoir. The Colorado River accounts for approximately 97 percent of inflows to Lake Mead (Westenburg and others, 2006; Turner and others, 2012). The remaining 3 percent of inflows are from the Las Vegas Wash, Muddy River, Virgin River, and ephemeral streams (Westenburg and others, 2006; Turner and others, 2012). From 1935 through 2001 the computed average combined inflow was $13,400 \mathrm{Mm}^{3}$ per year (yr; 10,860 Kaf/yr; Ferrari, 2008). During the 1999-2010 drought period, average inflows were reduced to $10,100 \mathrm{Mm}^{3} / \mathrm{yr}(8,190 \mathrm{Kaf} / \mathrm{yr}$; Turner and others, 2012). Average inflows for the period of this study, 2010 through 2019 , were $12,008 \mathrm{Mm}^{3} / \mathrm{yr}(9,735 \mathrm{Kaf} / \mathrm{yr})$.

The watershed area draining to Lake Mead is approximately $435,000 \mathrm{~km}^{2}\left(168,000 \mathrm{mi}^{2}\right)$, or 5 percent of the United States (Thomas, 1954). The reservoir is at full capacity when the water-level elevation is $374.6 \mathrm{~m}(1,229 \mathrm{ft})$ above mean sea level. At full capacity, the total storage is $34,069 \mathrm{Mm}^{3}(27,620$ $\mathrm{Kaf})$ and the surface area is $659.3 \mathrm{~km}^{2}(162,916$ acres; Tighi and Callejo, 2011).

Lake Mead consists of a series of basins separated by narrower reaches. Boulder Basin (the most downstream basin nearest to Hoover Dam) and Virgin Basin (the next upstream basin) account for approximately 60 percent of the total storage in the lake (Thomas, 1954). Lake depths are up to approximately $140 \mathrm{~m}(460 \mathrm{ft})$ and widths range from $200 \mathrm{~m}(656 \mathrm{ft})$ in the narrow canyons to 16 kilometers $(\mathrm{km} ; 10 \mathrm{mi})$ in the larger basin areas. Lake water generally is clear, and small currents are related to lake circulation (Thomas, 1954). The average residence time of water moving through Lake Mead has been estimated as 3.9 years (Westenburg and others, 2006) and 2.6 years (Turner and others, 2012). 
Flow through Hoover Dam is through the four intake towers located above the dam. Water supply for the powerplant turbines is drawn through the intake towers by a combination of upper gates at an elevation of $1,050 \mathrm{ft}$ and lower gates at an elevation of $895 \mathrm{ft}$. Water flows from the intake towers through a series of penstocks where flow is measured, then the water flows out through the tailrace where water quality and temperature are measured.

\section{Lake Mohave}

Lake Mohave extends approximately $67 \mathrm{mi}$ along a series of narrow canyons from Hoover Dam to Davis Dam, straddling the southern Nevada and northwestern Arizona border (fig. 1). Davis Dam was completed in 1953 as one of the last dams on the Colorado River and was built with a primary purpose to regulate Hoover Dam releases for delivery to Mexico (Ohmart and others, 1988). The lake follows the original river channel and has a maximum width of $6.4 \mathrm{~km} \mathrm{(4} \mathrm{mi)} \mathrm{and} \mathrm{a}$ maximum depth of $36.5 \mathrm{~m}(120 \mathrm{ft})$. Although water level is largely controlled by releases from Davis Dam, the reservoir is primarily riverine from below Hoover Dam through Black Canyon, before transitioning to true reservoir conditions in Eldorado Canyon (National Park Service, 2020). South of Eldorado Canyon, Lake Mohave gradually widens to its widest point in Cottonwood Cove.

Inflow to Lake Mohave is provided by releases from Hoover Dam and averaged $11,250 \mathrm{Mm}^{3} / \mathrm{yr}(9,120 \mathrm{Kaf} / \mathrm{yr})$ for the period of record of this study, May 2013-May 2019 (h ttps://www.usbr.gov/lc/region/g4000/24mo/index.html). The reservoir is at full capacity when the water-level elevation is $197.2 \mathrm{~m}(647 \mathrm{ft})$ above mean sea level. At full capacity, the total storage is $2,242 \mathrm{Mm}^{3}(1,818 \mathrm{Kaf})$, and the surface area is $113.3 \mathrm{~km}^{2}$ (28,000 acres; https://www.usbr.gov/projects/ index.php?id=47). Monthly mean lake elevations ranged from 634.8 to $644.7 \mathrm{ft}$ for the period of record for this study. The average residence time has been estimated at 60 days (Rosen and others, 2012).

The crest of Davis Dam is at an elevation of $655 \mathrm{ft}$, just above the high-water elevation of $647 \mathrm{ft}$ (Bureau of Reclamation, 1955). The height of the dam is $200 \mathrm{ft}$, with a dead storage pool elevation of $533 \mathrm{ft}$. The powerplant on Davis Dam is supplied with water through spillways and an outlet structure. Outflow water temperature is measured downstream of the spillway and represents surface-water temperature of the lake. Temperatures entering Lake Mohave from Hoover Dam are cold throughout the year (averaging 14 ${ }^{\circ} \mathrm{C}$ ) and stay cold throughout Black Canyon because shade from the steep walls of the canyon help maintain the temperature. Temperatures in the downstream Cottonwood Cove can be much warmer in the summer, which leads to a convergence zone in Eldorado Canyon as cold, nutrient-rich upstream water flows under the warmer lake water (National Park Service, 2020). The two waters are considered to have thoroughly mixed by the point at which water temperature is measured at the Davis Dam outflow.

\section{Methods of Study}

The following is an abbreviated discussion of the methods, which are fully provided in Moreo and Swancar (2013) and continued for this study. Methods to estimate lake evaporation generally fall into three categories: (1) aerodynamic methods, (2) energy balance methods, and (3) methods that combine these two approaches (Allen and others, 1998; Finch and Hall, 2005; Rosenberry and others, 2007). Eddy covariance is a micrometeorological method that also falls into the first category; when EC is corrected for energy balance closure it falls within the third category. The BREB method is in the second category.

The selection of a method or methods to estimate evaporation, each with its own strengths and weaknesses, is typically dictated by study objectives, the size and complexity of the study area, and costs. The primary objective of this study was to provide accurate monthly evaporation rates, which are expected to improve 24MS water budget and model output accuracy. The EC method was chosen as the primary method because it provides the most direct and least uncertain measure of monthly evaporation (Moreo and Swancar, 2013). Furthermore, even though the focus of this report is on monthly estimates, one significant advantage of the EC method over other methods is the ability to accurately measure daily and sub-daily evaporation. Processes that control open-water evaporation become more evident at these shorter time steps (Blanken and others, 2003; Liu and others, 2009; Granger and Hedstrom, 2011).

In this study, evaporation is calculated from latent heat following the Stull equation (Stull, 1988). The evaporation rate, $\mathrm{E}$, in $\mathrm{m} / \mathrm{s}$ is shown in the equation below:

$$
E=\frac{Q_{e}^{*} 1.8}{2501-2.37 * T_{a}}
$$

where

$$
\begin{aligned}
& Q_{e} \quad \begin{array}{r}
\text { is the latent-heat flux, or the energy used for } \\
\text { evaporation, in watts per square meter } \\
\left(\mathrm{W} / \mathrm{m}^{2}\right), \text { and }
\end{array} \\
& T_{a} \quad \text { is the air temperature in }{ }^{\circ} \mathrm{C} .
\end{aligned}
$$

Although latent heat is the primary component in evaporation calculations using the EC method, other energy gains and losses are used to refine evaporation results. Final evaporation results were adjusted using energy balance closure procedures.

\section{Energy Balance}

Excluding the energy fluxes considered negligible for the previous study, the energy balance of Lake Mead and Lake Mohave can be explained by the following equation (fig. 2; Moreo and Swancar, 2013): 


$$
Q_{n}-Q_{x}+Q_{v}=Q_{e}+Q_{h}
$$

where

$$
\begin{array}{ll}
Q_{n} & \text { is the net radiation, } \\
Q_{x} & \text { is the change in stored heat, } \\
Q_{v} & \text { is the net heat advected into the lake, } \\
Q_{e} & \text { is the latent-heat flux, or the energy used for } \\
\text { evaporation, and }
\end{array}
$$

All Q terms are expressed in $\mathrm{W} / \mathrm{m}^{2}$. The left side of the equation represents available energy, and the right side represents turbulent energy. Each of the energy fluxes in equation 2 is measured independently for the EC method.

\section{Eddy Covariance Turbulent Flux Measurements}

Eddies are turbulent airflow caused by wind, surface roughness, and convective heat flow in the atmospheric surface layer (Swinbank, 1951; Brutsaert, 1982; Kaimal and Finnigan, 1994). Eddies transfer energy and mass between land and water surfaces and the atmosphere (Brutsaert, 1982). The sum of $Q_{e}$ and $Q_{h}$ is referred to as turbulent flux, or turbulent energy, in $\mathrm{W} / \mathrm{m}^{2}$. The EC method provides the most direct measure of turbulent exchange available (Baldocchi, 2003; Foken, 2008; Stannard and others, 2013). Fluxes of water vapor and heat can be measured directly without the application of empirical constants by finding the covariance between these scalars and vertical wind speed (Foken, 2008; Campbell Scientific, Inc., 2010b). Evaporation (positive $\mathrm{Q}_{\mathrm{e}}$ ) occurs when water vapor in upward moving eddies is greater than in downward moving eddies. Likewise, $\mathrm{Q}_{\mathrm{h}}$ is positive (from the surface to the atmosphere) when upward moving eddies are warmer than downward moving eddies.

\section{Latent-Heat Flux $\left(\mathrm{O}_{\mathrm{e}}\right)$}

Latent-heat flux $\left(\mathrm{Q}_{\mathrm{e}}\right)$, as defined for this study, is the energy removed from the lakes during the liquid-to-vapor phase change of water and is the product of the latent heat of vaporization of water $(\lambda)$ and water-vapor flux density. The latent heat of vaporization, although slightly temperature dependent, is nearly constant. Water-vapor flux density is calculated as the covariance of instantaneous deviations from the time-averaged product of water-vapor density and vertical wind speed. Eddy covariance derived $\mathrm{Q}_{\mathrm{e}}$ can be expressed mathematically as the equation below:

$$
Q_{e}=\lambda \overline{w^{\prime} \rho_{v}^{\prime}}
$$

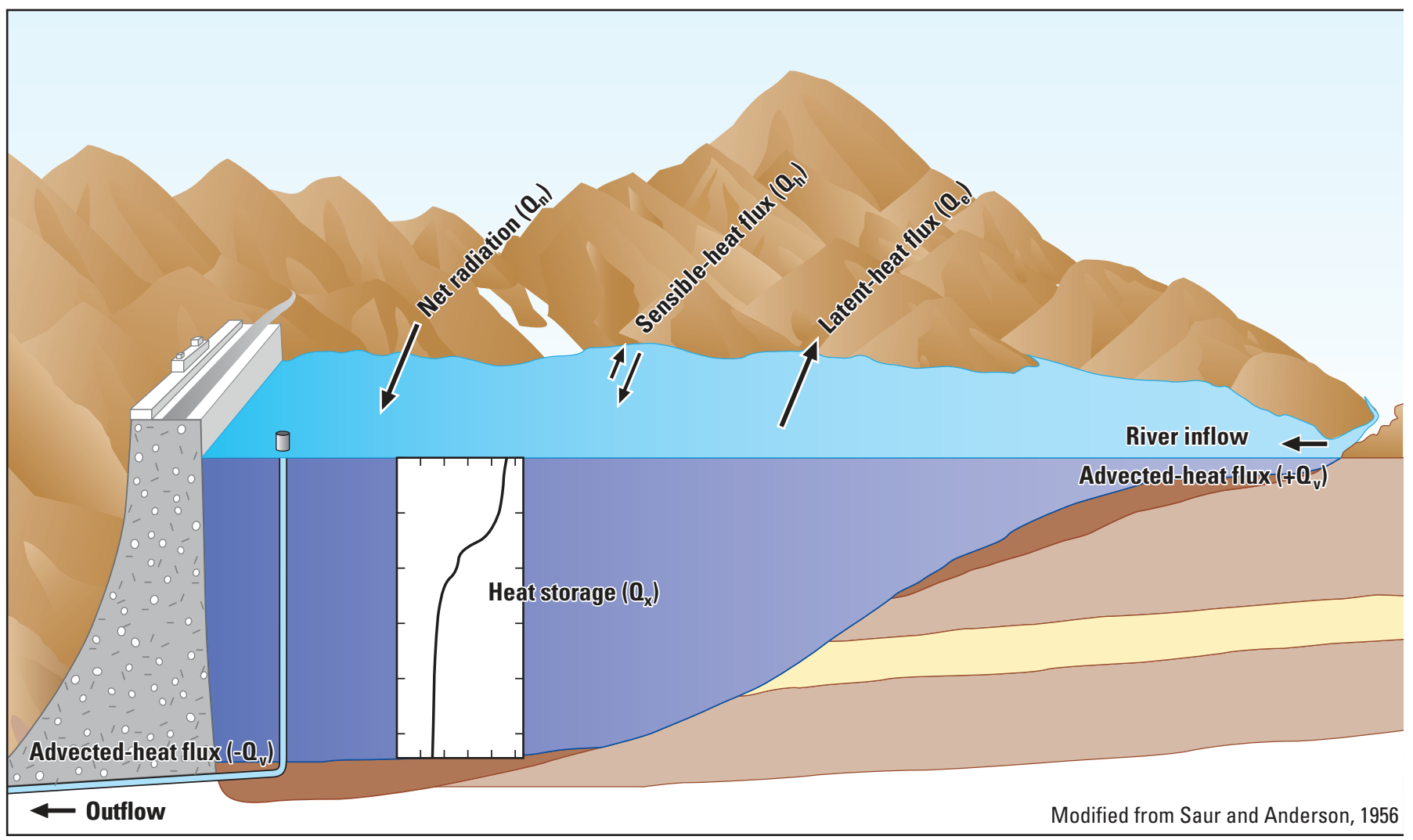

Figure 2. Major energy-budget components diagram. 
where

$$
\begin{aligned}
& w \quad \text { is the vertical component of wind } \\
& \text { speed, in } \mathrm{m} / \mathrm{s}, \\
& \rho_{v} \\
& \text { is the water vapor density, in grams (g) } \\
& \text { per } \mathrm{m}^{3} \text {, and } \\
& \text { are the primes that are deviations from } \\
& \text { mean values, and the overbar denotes } \\
& \text { mean value. }
\end{aligned}
$$

Deviations from mean values were measured at 10 hertz (Hz; 10 times per second), and mean values were computed over a 30-minute period. The $\mathrm{Q}_{\mathrm{e}}$ is converted to evaporation using equation 1.

\section{Sensible-Heat Flux $\left(0_{h}\right)$}

Sensible-heat flux $\left(Q_{h}\right)$ is the movement of heat energy that results from a temperature difference between the surface of the lake and the atmosphere. The EC method computes $\mathrm{Q}_{\mathrm{h}}$ from air temperature and vertical wind speed as the equation below:

$$
Q_{h}=\rho_{a} C_{p} \overline{w^{\prime} T_{a}^{\prime}}
$$

where

$$
\begin{aligned}
& \rho_{a} \quad \text { is the air density, in kilogram }(\mathrm{kg}) \text { per } \mathrm{m}^{3}, \\
& C_{p}^{a} \text { is the specific heat of air, in joules (J) } \\
& \text { per } \mathrm{kg}{ }^{\circ} \mathrm{C} \text {, } \\
& w \quad \text { is the vertical component of wind } \\
& \text { speed, in } \mathrm{m} / \mathrm{s} \text {, } \\
& T_{a} \quad \text { is air temperature, in }{ }^{\circ} \mathrm{C} \text {, and } \\
& \text { are the primes that are deviations from } \\
& \text { mean values, and the overbar denotes } \\
& \text { mean value. }
\end{aligned}
$$

\section{Energy Balance Closure}

Eddy covariance evaporation estimates in this study were adjusted for energy balance closure. Forced closure of the energy balance equation involves balancing the latent- and sensible-heat energy against independently measured available energy, as described in Moreo and Swancar (2013). Foken and others (2012) suggest that a first-order approximation for closing the energy balance can be achieved by applying the Bowen ratio to calculated evaporation. The Bowen ratio, the ratio of $\mathrm{Q}_{\mathrm{h}}$ to $\mathrm{Q}_{\mathrm{e}}$, has been traditionally important in determining energy balance in evapotranspiration studies (Bowen, 1926).

In this study, the EBR or the ratio of turbulent fluxes to available energy, is used to quantify energy balance closure (Moreo and Swancar, 2013). The EBR is computed as follows in the equation below:

$$
E B R=\frac{Q_{e}+Q_{h}}{Q_{n}-Q_{x}+Q_{v}}
$$

where

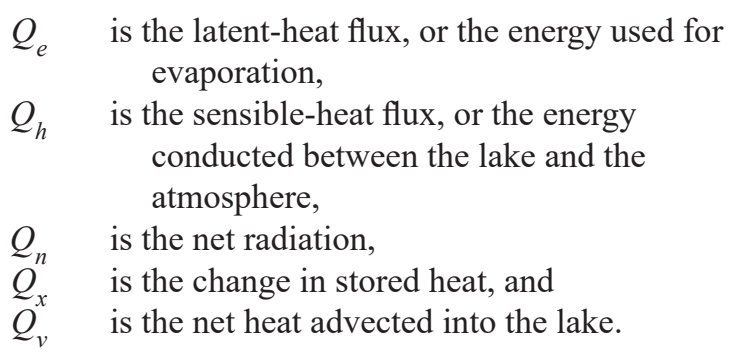

If all known energy fluxes appear in the energy budget equation and all energy fluxes are measured accurately, then the EBR would equal unity; this concept is commonly called energy balance closure. In reality, the sum of EC turbulent energy is consistently less than the sum of available energy, with various explanations given for the source of the discrepancy (Wilson and others, 2002; Foken, 2008; Foken and others, 2012; Leuning and others, 2012). Wilson and others (2002) studied the results of other investigators and reported annual EBR values ranging from 0.39 to 1.69 for 50 siteyears of data at $22 \mathrm{EC}$ sites, with an average value of 0.8 , thus implying that on average 80 percent of available energy is accounted for by turbulent energy measurements. This lack of energy balance closure is quantifiable because the EC system measures latent- and sensible-heat energy independently.

Foken and others (2012) suggest that the lack of closure at many EC sites is not related to errors in the EC method but instead is related to atmospheric conditions that cannot be measured using the EC method. When airflow contacts significant landscape heterogeneities, large eddies are formed and a secondary atmospheric circulation pattern is developed; therefore, these secondary circulation patterns are not uniformly distributed over an area. Furthermore, these secondary circulation patterns are characterized by the transfer of energy from small to very large (greater than $1 \mathrm{~km}$ ) eddies. The time of passage of these very large eddies likely is too long for the typical 30-minute to 1-hour averaging periods to capture; however, longer averaging periods begin to violate the principles of stationarity. The resulting advective flux divergence is difficult to detect.

In this study, energy balance closure is achieved by dividing evaporation estimates by the annual EBRs. When the EBR is less than 1, measured evaporation is adjusted upwards for closure, and the corrected results represent maximum evaporation. When the EBR is greater than 1, turbulent fluxes are overestimated compared to available energy so measured evaporation must be adjusted downwards for closure, and the adjusted results represent minimum evaporation. In this study, reported evaporation is the average of the measured and corrected evaporation. 


\section{Available Energy Measurements}

Available energy is comprised of net radiation $\left(Q_{n}\right)$, change in stored heat $\left(Q_{x}\right)$, and advected heat $\left(Q_{v}\right)$. Two of the available energy parameters $\left(Q_{n}\right.$ and $\left.Q_{x}\right)$ were measured directly by the USGS using instrumentation installed on floating platforms for this study. Advected heat was calculated using temperature and inflow and outflow data collected by Reclamation and USGS.

\section{Net Radiation $\left(0_{n}\right)$}

Net radiation $\left(\mathrm{Q}_{\mathrm{n}}\right)$ was measured either directly using net radiometers or indirectly using solar radiometers and an established relationship between measured $\mathrm{Q}_{\mathrm{n}}$ and solar radiation $\left(\mathrm{Q}_{\mathrm{s}}\right)$. Net radiation was measured from the floating platforms and $\mathrm{Q}_{\mathrm{s}}$ was measured from the land-based EC stations. At Lake Mead, $\mathrm{Q}_{\mathrm{n}}$ was measured using net radiometers from the Sentinel Island floating platform (May 21, 2010, to April 22, 2013; Moreo and Swancar, 2013) and the Boulder Basin floating platform (April 22, 2013, to April 25, 2017; Moreo, 2018). At Lake Mohave, $Q_{n}$ was measured using a net radiometer from the Lake Mohave floating platform (April 11, 2013, to September 30, 2016; Moreo, 2018). Solar radiation was measured at the Lake Mead EC station from March 28, 2015, to April 30, 2019, and at the Lake Mohave EC station from March 20, 2015, to April 30, 2019.

After the floating platforms were removed in 2016 for Lake Mohave and in 2017 for Lake Mead, $Q_{n}$ was estimated from a period of paired $Q_{n} / Q_{s}$ measurements at each lake. At Lake Mead, this estimation is based on the strong relation between $\mathrm{Q}_{\mathrm{n}}$ measured at the Boulder Basin platform and $\mathrm{Q}_{\mathrm{s}}$ measured at the EC2 site $\left(\mathrm{y}=1.01 \mathrm{x}-86.24, \mathrm{r}^{2}=0.97, \mathrm{n}=17,519\right.$ half-hourly measurements) and was applied from April 19, 2017, to April 30, 2019 (fig. 3). At Lake Mohave, this estimation is based on a strong relation between $Q_{n}$ measured at the floating platform and $\mathrm{Q}_{\mathrm{s}}$ measured at the $\mathrm{EC} 1$ site ( $\mathrm{y}=0.94 \mathrm{x}-78.31, \mathrm{r}^{2}=0.92, \mathrm{n}=17,567$ half-hourly measurements; fig. 4).

\section{Change in Stored Heat $\left(Q_{x}\right)$}

Change in stored heat $\left(Q_{x}\right)$ was calculated from watertemperature profiles at the floating platforms. Temperatures to $76 \mathrm{~m}(250 \mathrm{ft})$ depth (or the maximum depth measured if greater than $76 \mathrm{~m}$ ) at Lake Mead and temperatures to $26 \mathrm{~m} \mathrm{(85}$ $\mathrm{ft}$ or maximum depth) at Lake Mohave were used to calculate $\mathrm{Q}_{\mathrm{x}}$. Below $76 \mathrm{~m}$ depth, water temperature at Lake Mead varies little (Veley and Moran, 2012). The temperature data, as measured at various depths as layers, were combined with lake stage and bathymetric data to obtain $\mathrm{Q}_{\mathrm{x}}$ using the following equation (modified from Anderson and Pritchard, 1951, p. 101, equation 93, and from Dave Stannard, U.S. Geological Survey, written commun., 2010):

$Q_{x}=\frac{1}{t}\left[\begin{array}{c}\sum_{i-1}^{n} C_{w}\left(T_{i}^{t}-T_{b}\right) A_{i}^{t} T H_{i}+C_{w}\left(T_{c}^{t}-T_{b}\right) A_{c}^{t} T H_{c}^{t}- \\ \sum_{i-1}^{n} C_{w}\left(T_{i}^{t-1}-T_{b}\right) A_{i}^{t-1} T H_{i}+C_{w}\left(T_{c}^{t-1}-T_{b}\right) A_{c}^{t-1} T H_{c}^{t-1}\end{array}\right]$

where

$$
\begin{aligned}
& Q_{x} \quad \text { is the change in heat stored per unit surface } \\
& \text { area of a water body, in } \mathrm{W} / \mathrm{m}^{2} \text {, } \\
& 1 \text { refers to the first (top) layer, } \\
& t \text { is the length of measurement period, } \\
& \text { in seconds, } \\
& n \quad \text { refers to the second from the bottom layer } \\
& \text { (constant thickness layer), } \\
& i \quad \text { (subscript) is the } i \text { th layer, } \\
& C_{w} \quad \text { is the volumetric specific heat of water, equal } \\
& \text { to } 4.187 \times 10^{6} \mathrm{~J} / \mathrm{m}^{3}{ }^{\circ} \mathrm{C} \text {, } \\
& T \text { is the average temperature of a layer, in }{ }^{\circ} \mathrm{C} \text {, } \\
& t \text { (superscript) is the end of the } \\
& \text { measurement period, } \\
& T_{b} \text { is the base temperature (assumed zero), in }{ }^{\circ} \mathrm{C} \text {, } \\
& t-1 \quad \text { (superscript) is the beginning of the } \\
& \text { measurement period, } \\
& A \text { is the surface area of the lake, in } \mathrm{m}^{2} \text {, } \\
& \mathrm{TH} \text { is the thickness of layer in which temperature } \\
& \text { change is measured in } \mathrm{m} \text {, and } \\
& \text { c (subscript) is the bottom layer (variable } \\
& \text { thickness layer). }
\end{aligned}
$$

Temperature profiles measured just after midnight (0000-0060 hour) on the first day of the month were used to quantify the monthly $\mathrm{Q}_{\mathrm{x}}$. Layer thickness $(T H)$ was $5 \mathrm{~m}$ at Lake Mead and $2.5 \mathrm{~m}$ at Lake Mohave except for the top and bottom layers; the top layer was 1-m thick and the bottom layer thickness varied based on the lake level. The average temperature of each layer $(T)$ was computed as the average of the temperatures measured at the top and the bottom of the layer. Surface area $(A)$ for each layer was the average of the top and bottom layer areas, determined from lake stage and storage relationship (Tighi and Callejo, 2011). The total stored heat for the lake at the beginning of each month was the sum of the heat contents of all the layers. Change in stored heat was then calculated as the difference between the total stored heat from one month to the next. Following the end of the water-quality program in 2016 and the removal of the floating platforms, $Q_{x}$ was estimated based on an average of the 3 previous years of data. 
$114^{\circ} 48^{\prime}$

$114^{\circ} 45^{\prime}$

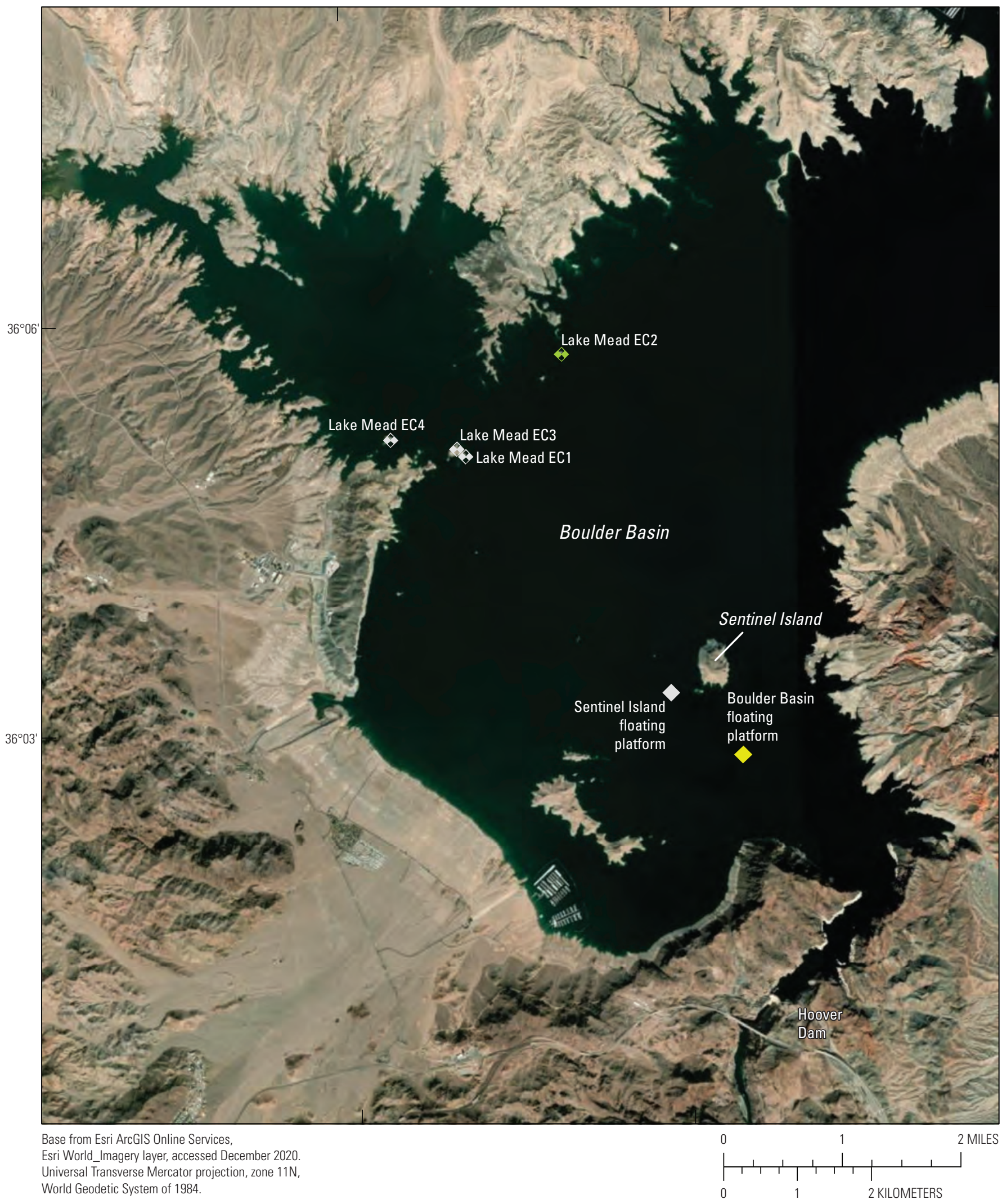

Figure 3. Overview showing eddy covariance $(\mathrm{EC})$ and floating platform sites in Boulder Basin, Lake Mead, Nevada and Arizona. 


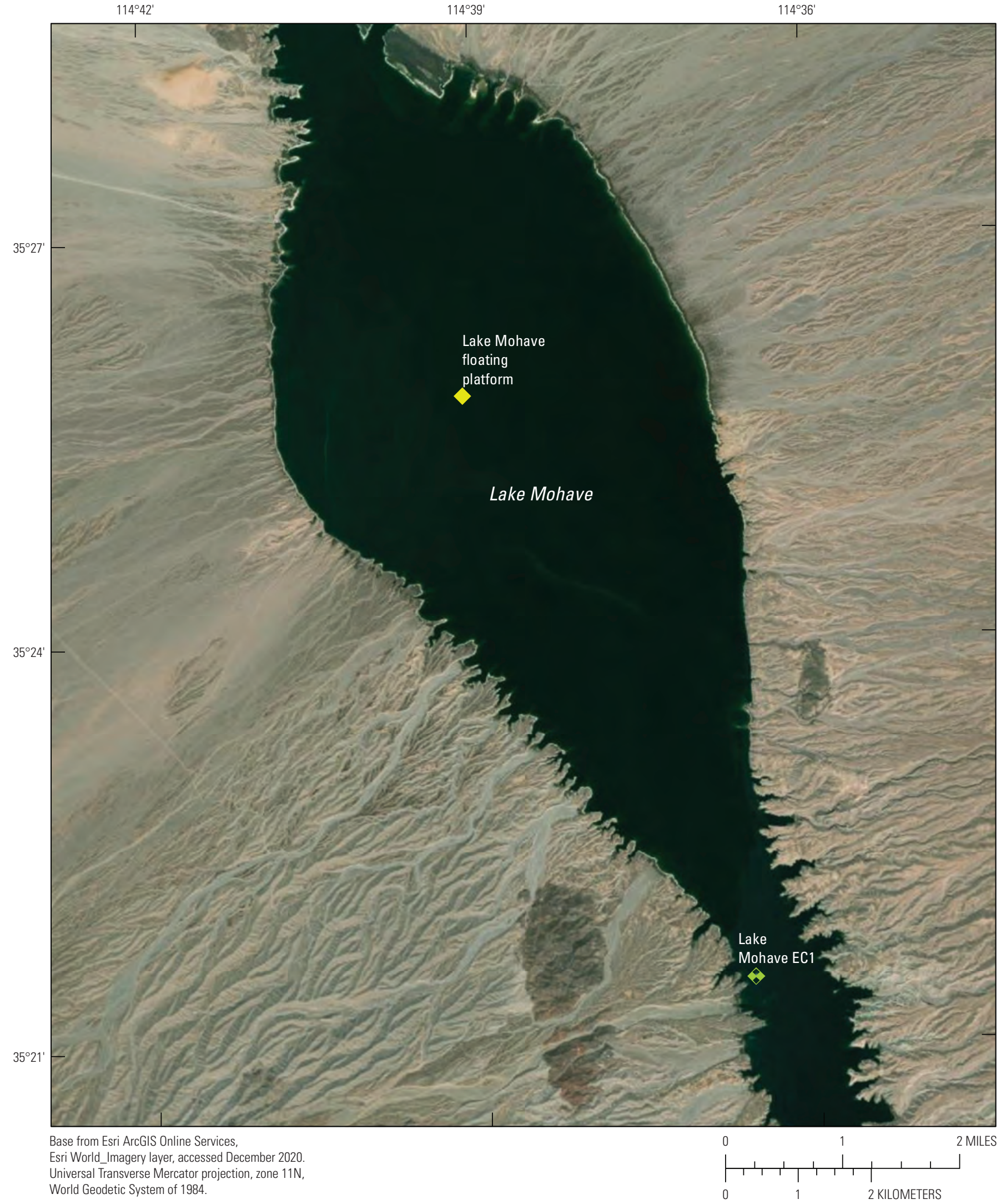

Figure 4. Overview showing eddy covariance (EC) and floating platform sites, Lake Mohave, Nevada and Arizona. 


\section{Advected Heat $\left(\mathrm{Q}_{\mathrm{v}}\right)$}

Net $Q_{V}$ to Lake Mead and Lake Mohave is the difference between inflowing and outflowing heat, which enters and leaves the lake along with water gains and losses. Net $Q_{V}$ was calculated using the following equation (Omar and ElBakry, 1981):

$$
Q_{v}=\frac{\left[\sum_{i=1}^{n} C_{w} V_{i}\left(T_{i}-T_{b}\right)-\sum_{o=1}^{m} C_{w} V_{o}\left(T_{o}-T_{b}\right)\right]}{A t}
$$

where

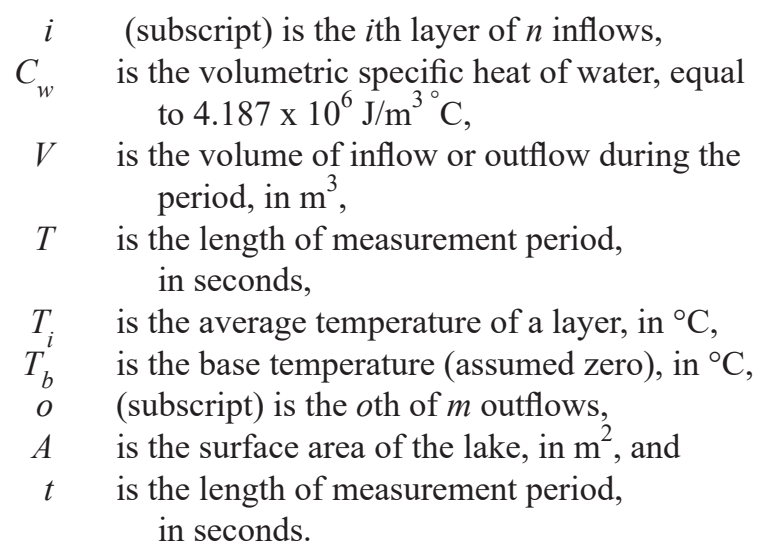

The primary inflow into Lake Mead is from the Colorado River and was calculated using Glen Canyon Dam releases. Major side inflows and outflows of Lake Mead are composed of the Virgin River, the Muddy River, withdrawals for municipal use in the Las Vegas Valley by the Southern Nevada Water Project (SNWP), and bank storage. All flow data were provided by the $24 \mathrm{MS}$. Advected heat at Lake Mohave was calculated using Hoover Dam inflow and Davis Dam outflow temperature and flow data. Inflow temperatures to Lake Mead were estimated primarily using the USGS Grand Canyon Monitoring and Research Center monitoring site 09404220, Colorado River above Spencer Creek at river mile (RM) 246 (Voichick and Wright, 2007; Wright and others, 2009). Monthly averaged temperature data were computed using continuous 15-minute temperature data measured at either RM 226 or RM 246 (fig. 1). The upstream end of the lake was at approximately RM 280 during the study (fig. 1). Temperature changes in the river downstream from the last measurement point and their effects on $\mathrm{Q}_{\mathrm{V}}$ and lake evaporation were assumed negligible based on the Colorado River temperature model developed by Wright and others (2009). A more detailed temperature discussion can be found in Moreo and Swancar (2013).

Temperature of the outflow from Lake Mead (Hoover Dam) is measured at the tailrace and was provided by Reclamation. All volume and temperature side flow data were provided by Reclamation's 24MS. Temperatures of the SNWP withdrawals from Lake Mead were used for the monthly average lake surface temperature. Temperatures of water going into and out of bank storage at Lake Mead were assumed to be equal to the monthly average lake surface temperature when the lake level was rising, and equal to the long-term (24-month) average lake surface temperature (a surrogate for groundwater temperature) when the lake level was falling. Lake Mead outflow temperature is assumed to be the same as Lake Mohave inflow temperature. Lake Mohave outflow temperature and flow data were measured at the tailrace of Davis Dam and provided by Reclamation.

\section{Vapor Pressure Difference}

Because evaporation is proportional to vapor pressure differences (Moreo and Swancar, 2013), vapor pressure differences can be computed at the floating platforms as an independent check on EC measurements. Saturation vapor pressure of the air at $1.74 \mathrm{~m}$ above the water surface $\left(e_{a}\right)$ was measured with a CS HC2S3 temperature and relative humidity probe from the floating platforms at both lakes. Vapor pressure at the water-surface temperature $\left(e_{o}\right)$ was computed with relative humidity and water-surface temperatures were measured with a CS 107 temperature probe.

Air temperature, water temperature, and relative humidity was measured from April 22, 2013, to April 25, 2017, at Lake Mead and from April 1, 2013, to September 30, 2016, at Lake Mohave. Average monthly vapor pressures and vapor pressure differences were calculated from 30-minute temperature and relative humidity data.

\section{Sites}

Floating platforms and EC stations were established in 2010 in Lake Mead and in 2013 in Lake Mohave (table 2). The sensors necessary to measure available energy were installed on the floating platforms, while sensors necessary to measure turbulent flux were installed at the EC sites. While floating platforms had previously been deployed on Lake Mead for various water-quality studies, deploying EC sensors from a raft is impractical because the wave-induced raft movement interferes with the EC measurements.

The ideal site placement for an EC station is one where the terrain surrounding the site is flat and homogeneous, and where the fetch for the surface-of-interest is longer than the turbulent-flux source area. Fetch is defined in this study as the upwind distance from the measurement point to the shore, and the surface-of-interest is open water. The fetch needs to be long enough for airflow measured by EC sensors to equilibrate to the open-water evaporating surface (Rosenberry and others, 2007). Eddy covariance stations were located on small rock outcrops exposed by declining lake levels in Lake Mead (fig. 3) and on the eastern tip of Cottonwood Island at Lake Mohave (fig. 4). Because of the shape of Cottonwood Island, an additional fetch filter was applied to turbulent flux measurements at Lake Mohave when wind passing over the western portion of the island was between 225 and 275 
azimuth degrees. The fetch filter applied to less than 3 percent of the latent-heat and sensible-heat values $(3,115$ of 105,434 30-minute unit values were filtered when wind direction was over the island). The need for this filter was not identified until 2019 , but because it addresses physical characteristics of the island (which did not change over the course of the study) this filter was retroactively applied to Lake Mohave data from May 2013 to April 2019.

The sites were usually visited each month for routine maintenance and data acquisition. Instrumentation were also checked and evaluated routinely and repaired or replaced as necessary. The net radiometer was checked for proper level and cleaned with water as necessary. The EC sensors, krypton hygrometers (KH20), and sonic anemometers (CSAT3) were cleaned and checked for positioning. The solar panels were cleaned of dust and debris and batteries were routinely refilled with distilled water. The precipitation gage measuring tube was recharged with mineral oil when emptied after measuring.

\section{Instrumentation for Turbulent Flux Measurements}

Two specialized sensors were used for turbulent flux measurements - a KH20 measured water-vapor density fluctuations, and a CSAT3 measured three-dimensional wind-vector and air-temperature fluctuations (fig. 5). A krypton lamp in the KH20 sensor emits an ultraviolet radiation signal along an approximately $1-\mathrm{cm}$ path open to the atmosphere (Campbell Scientific, Inc., 2010a). The signal is attenuated according to the Beer-Lambert law as water vapor absorbs specific frequencies of ultraviolet radiation. A voltage output proportional to the attenuated signal is recorded and related to water-vapor density by a regression function. The CSAT3 measures turbulent fluctuations of horizontal and vertical wind speed using three pairs of non-orthogonally oriented transducers to transmit and receive an ultrasonic signal (Campbell Scientific, Inc., 2010b). The Doppler effect relates the flight time of the signal to wind speed (Campbell Scientific, Inc., 2010b). A CR3000 electronic datalogger (Campbell Scientific, Inc, 2018a) received output from these sensors at a frequency of $10 \mathrm{~Hz}(10$ times per second). The centers of the $\mathrm{KH} 2 \mathrm{O}$ and CSAT3 signal

Table 2. Location and general description of measurement sites, Lake Mead and Lake Mohave, Nevada and Arizona.

[U.S. Geological Survey site identification: Unique identification number for site as stored in files and databases of the U.S. Geological Survey. Abbreviations: USGS, U.S. Geological Survey; mm/dd/yyyy, month/day/year; EC, Eddy covariance]

\begin{tabular}{|c|c|c|c|c|c|}
\hline Site name & $\begin{array}{c}\text { U.S. Geological Survey site } \\
\text { identification number }\end{array}$ & Longitude & Latitude & $\begin{array}{l}\text { Period of reported measure- } \\
\text { ments (mm/dd/yyyy) }\end{array}$ & Reference \\
\hline $\begin{array}{l}\text { Lake Mead } \\
\quad \text { EC1 }\end{array}$ & 360500114465601 & 3995454 & 699677 & $03 / 01 / 2010$ to $05 / 24 / 2011$ & $\begin{array}{l}\text { Moreo and } \\
\text { Swancar, } 2013\end{array}$ \\
\hline $\begin{array}{l}\text { Lake Mead } \\
\quad \text { EC2 }\end{array}$ & 360500114465601 & 3996845 & 700974 & $\begin{array}{l}05 / 24 / 2011 \text { to } 08 / 25 / 2011 \\
05 / 08 / 2013 \text { to } 05 / 01 / 2019\end{array}$ & $\begin{array}{l}\text { Moreo and } \\
\text { Swancar, 2013; } \\
2020 \text { study }\end{array}$ \\
\hline $\begin{array}{l}\text { Lake Mead } \\
\text { EC3 }\end{array}$ & 360500114465601 & 3995555 & 699560 & $\begin{array}{l}08 / 25 / 2011 \text { to } 11 / 23 / 2011 ; \\
06 / 19 / 2012 \text { to } 05 / 08 / 2013\end{array}$ & $\begin{array}{l}\text { Moreo and } \\
\text { Swancar, 2013; } \\
2020 \text { study }\end{array}$ \\
\hline $\begin{array}{l}\text { Lake Mead } \\
\text { EC4 }\end{array}$ & 360500114465601 & 3995677 & 698662 & $11 / 23 / 2011$ to $06 / 19 / 2012$ & $\begin{array}{l}\text { Moreo and } \\
\text { Swancar, } 2013\end{array}$ \\
\hline $\begin{array}{l}\text { Lake Mead } \\
\text { Sentinel } \\
\text { Island plat- } \\
\text { form }\end{array}$ & 360314114450500 & 3992265 & 702540 & $03 / 01 / 2010$ to $04 / 22 / 2013$ & $\begin{array}{l}\text { Moreo and } \\
\text { Swancar, } 2013\end{array}$ \\
\hline $\begin{array}{l}\text { Lake Mead } \\
\text { Boulder } \\
\text { Basin plat- } \\
\text { form }\end{array}$ & 360246114443000 & 3991423 & 703436 & $04 / 22 / 2013$ to $04 / 25 / 2017$ & Moreo, 2018 \\
\hline $\begin{array}{l}\text { Lake Mohave } \\
\text { EC1 }\end{array}$ & 352129114363501 & 3914696 & 717197 & $05 / 01 / 2013$ to $04 / 30 / 2019$ & 2020 study \\
\hline $\begin{array}{l}\text { Lake Mohave } \\
\text { floating } \\
\text { platform }\end{array}$ & 352550114390700 & 3923324 & 713155 & $04 / 11 / 2013$ to $09 / 30 / 2016$ & Moreo, 2018 \\
\hline
\end{tabular}


paths were separated by $10 \mathrm{~cm}$ horizontally and both sensors were positioned vertically. Solar radiation was measured with an Apogee CS300 pyranometer (Campbell Scientific, Inc., 2018b), air temperature and relative humidity was measured with a Rotronic HC2S3 probe (Campbell Scientific, Inc., 2017), and rain was measured with a NovaLynx: 260-2510 standard rain gauge (NovaLynx, 2007). The orientation and positioning of the sensors were selected during each installation to minimize airflow disruptions that could be caused by the support structure and other sensors. All instruments were calibrated by the manufacturer shortly before installation and recalibrated according to manufacturer guidelines.

\section{Instrumentation for Available Energy Measurements}

The floating platforms were initially installed in Lake Mead as part of a large project to collect near-continuous, depth-dependent water-quality data (Veley and Moran, 2012). In 2013, evaporation instruments were added to the platform to provide data to calculate available energy, and an identical platform was installed on Lake Mohave (fig. 6). A Kipp
\& Zonen NR-LITE2 net radiometer, a CS300 pyranometer, a Campbell Scientific 107 water-surface temperature probe, an $\mathrm{HC} 2 \mathrm{~S} 3$ temperature and relative humidity probe, and a Windsonic1 2-D sonic anemometer were installed on the platforms during most of the study. Radiation sensors were oriented facing south to eliminate shading from other parts of the platform. Platform orientation was maintained using two anchors, with lines adjusted periodically as the lake stage rose and fell to maintain tension. Some shifting of the platform orientation and level was inevitable, especially during strong winds, but it was assumed to be less than 10 degrees in any direction and not to have affected the $\mathrm{Q}_{\mathrm{n}}$ measurements substantially.

Water-temperature profiles of the lakes are required to calculate $\mathrm{Q}_{\mathrm{x} \text {. }}$ An automated variable-depth winch on each platform lowered a multiparameter sonde to measure a watertemperature profile every 6 hours starting at midnight (Veley and Moran, 2012). The first water-temperature measurement was at $1 \mathrm{~m}$ depth, and each successive measurement was 5 $\mathrm{m}$ deeper until just above the lake bottom. The total depth of the temperature profile for Lake Mead during the study varied

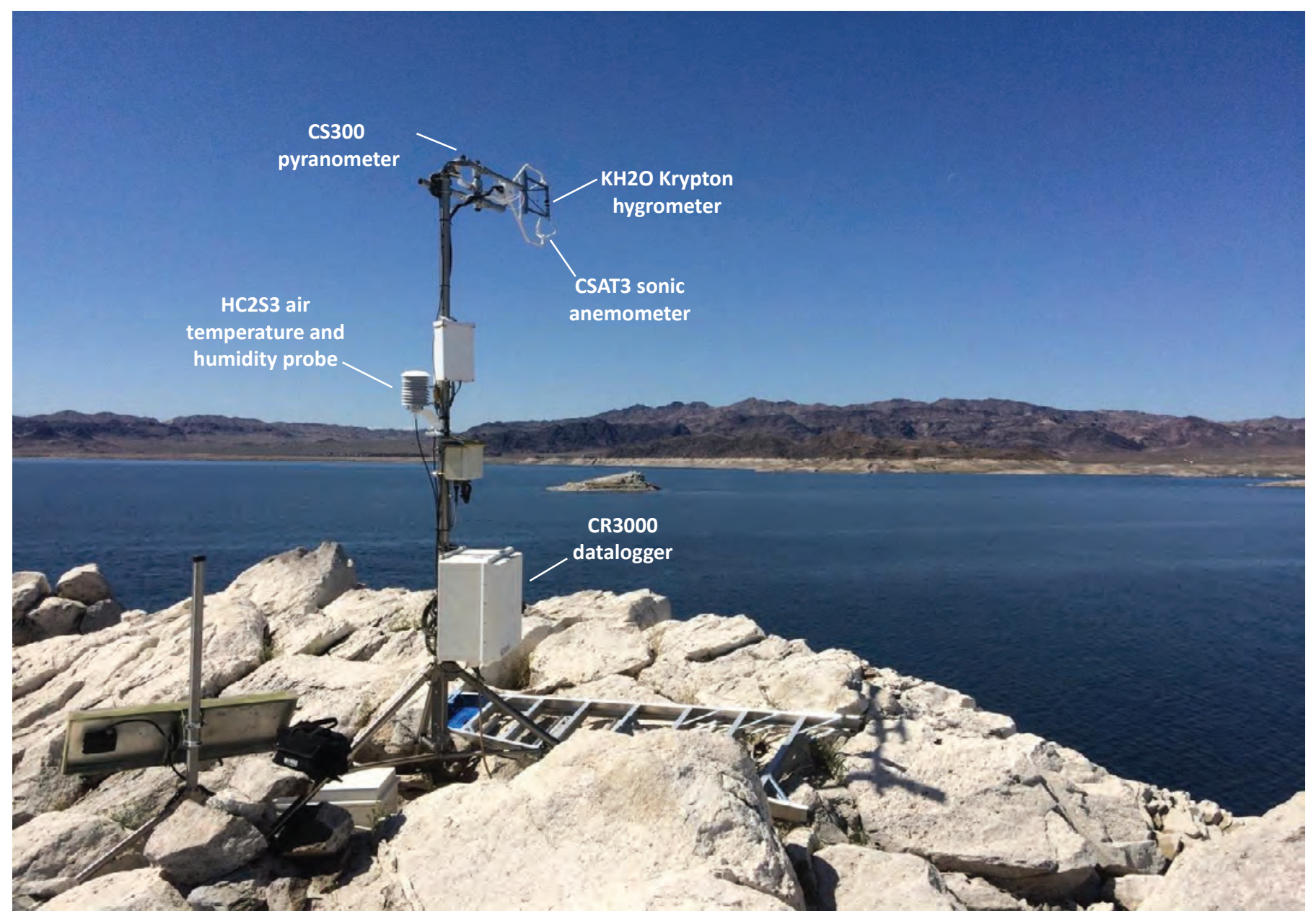

Figure 5. Eddy covariance station, EC2, showing turbulent flux sensors position, Lake Mead, Nevada and Arizona 
from $61 \mathrm{~m}$, when the lake stage was at its low point, to $81 \mathrm{~m}$ at its high point. Total depth at Lake Mohave ranged from 23.5 to $28.5 \mathrm{~m}$ while the floating platforms were active.

Net radiation was measured by three radiometers over the course of the study. The primary sensor at Lake Mead from 2010 until June 2012 was a 2-component (net shortwave and longwave radiation) radiometer (Model CNR2; Campbell Scientific, Inc., 2010c). From June 2012 to April 2017, $Q_{n}$ was measured on the Lake Mead and Lake Mohave platforms using a NR-LITE2 net radiometer (fig. 6; Campbell Scientific, Inc., 2019). A 4-component (incoming and outgoing shortwave and longwave radiation) radiometer (Model CNR1) of higher quality than the other net radiometers used for the study was periodically deployed on Lake Mead for use as a reference meter for both lakes (Campbell Scientific, Inc., 2011). Net radiation measurements were adjusted to achieve consistency between sensors and station locations based on comparisons to readings from the CNR1. From April 2017 until May 2019, $\mathrm{Q}_{\mathrm{s}}$ was measured using CS300 pyranometers at the Lake Mead and Lake Mohave EC stations and converted to $Q_{n}$ using relations developed between coincident $\mathrm{Q}_{\mathrm{s}}$ and $\mathrm{Q}_{\mathrm{n}}$ measurements (fig. 5).

\section{Data Collection and Reduction Procedures}

Raw EC data were collected as a 10-Hz time series data and were post-processed using EdiRe software (Campbell Scientific, Inc., 2008). Thirty-minute, block-averaged covariances (eqs. 4 and 5) were computed from sampled 10-Hz data after filtering spikes (Højstrup, 1993) and removing any lag between CSAT3 and KH2O signal outputs.

Poor-quality or unrepresentative 30-minute flux data were identified and removed by applying filters for the following situations (1) attenuation of the KH2O millivolt output signal caused by water accumulation during precipitation events, (2) greater than 10 percent of the 18,000 individual measurements by the CSAT3 that make up a 30-minute block average either filtered or missing, or (3) spikes of $\mathrm{KH}_{2} 0 \mathrm{Q}_{\mathrm{e}}$ and $\mathrm{Q}_{\mathrm{h}}$ measurements outside of expected ranges (based on visual inspection of site-specific historical ranges and Ameriflux guidance from Law and others, 2005).

Several commonly used corrections were applied to raw EC measurements to compensate for limitations both in the EC theory and equipment design. To correct errors associated with small misalignments of the CSAT3, raw covariances were two-dimensionally rotated to align with the mean streamlines of airflow, which forced the mean vertical and

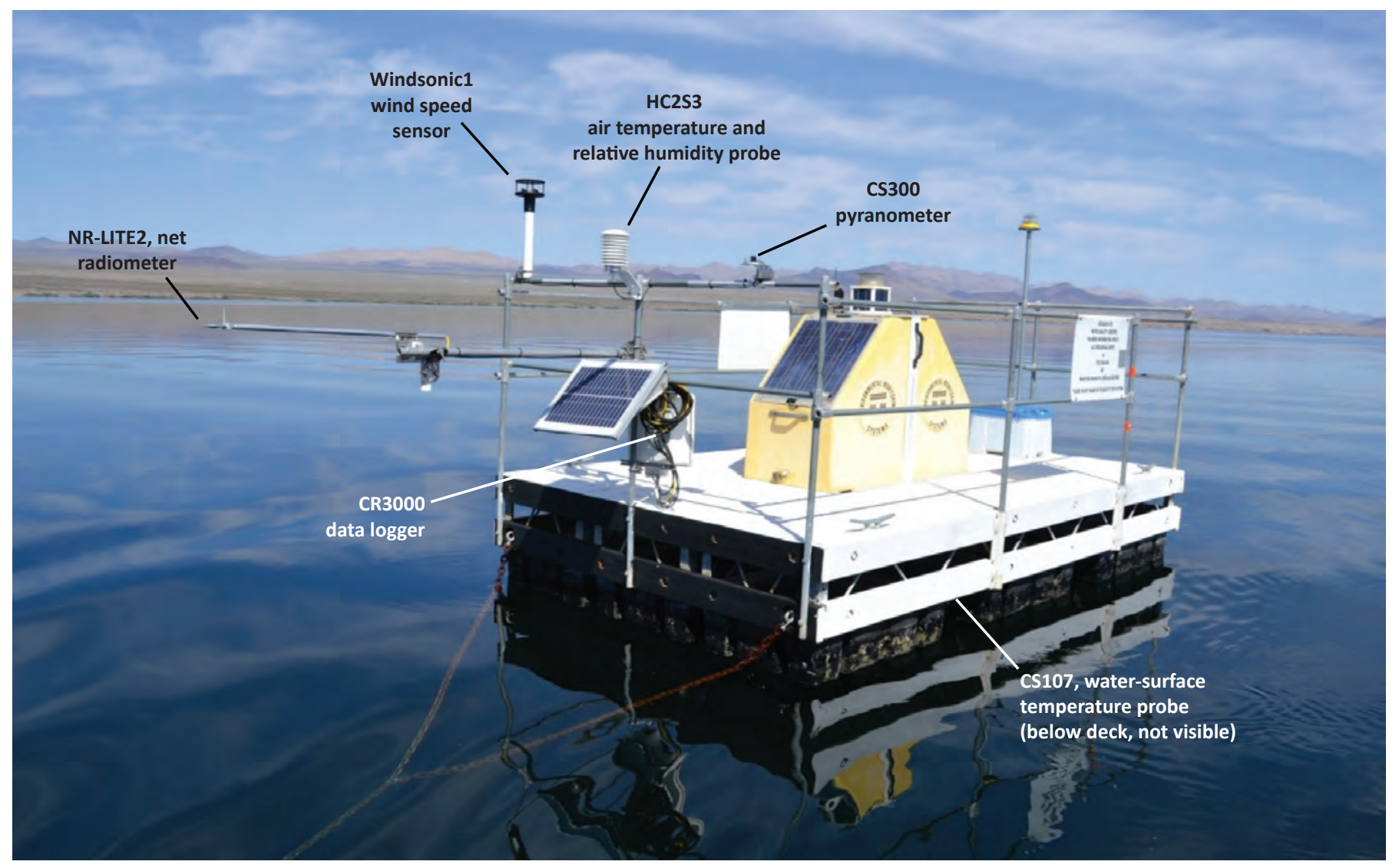

Figure 6. Floating platform showing available energy sensor positioning, Lake Mohave, Nevada and Arizona. 
crosswind velocities to zero (Kaimal and Finnigan, 1994). Frequency response corrections were applied that compensate for the inability of eddy sensors to measure contributions from the largest (greater than $1 \mathrm{~km}$ ) and smallest (less than $10 \mathrm{~cm}$ ) eddies due to averaging time and sensor geometry such as path-length averaging and sensor separation (Moore, 1986). The contribution to non-zero average vertical wind speed caused by variations in the density of rising and falling air is corrected following Webb and others (1980). The slight attenuation of the KH20 signal caused by oxygen in the $1-\mathrm{cm}$ signal path, which is proportional to the $\mathrm{Q}_{\mathrm{h}}$, was corrected as suggested by Tanner and Greene (1989). In addition, $\mathrm{Q}_{\mathrm{h}}$ data were corrected for air density and sound-path deflection of sonic-derived temperatures (Schotanus and others, 1983). An additional filter was applied to Lake Mohave EC data to remove data when wind passed over the western portion of Cottonwood Island (from 225 to 275 compass degrees).

Net radiation was corrected for wind speed when wind speed was less than $5 \mathrm{~m} / \mathrm{s}$ following the NR-LITE2 manual (Campbell Scientific, Inc., 2019). A CNR1 4-component reference radiometer was used to calibrate the CNR2 and NRLite2 net radiometers installed on the floating platforms. The calibration corrections are statistical regressions based on a period of dual service when both the NRLite2s and the CNR1 were active in 2015. A CNR1 regression equation of $Y=1.0729 x$ -1.3791 was applied to $\mathrm{Q}_{\mathrm{n}}$ data at Lake Mead from March 1, 2013, to April 19, 2017. A CNR1 regression equation of $\mathrm{Y}=1.0862 \mathrm{x}+3.77$ was applied to $\mathrm{Q}_{\mathrm{n}}$ data at Lake Mohave from March 1, 2013, to September 30, 2016.

\section{Gap Filling Missing or Bad Turbulent-Flux Data}

Once questionable data were identified and removed, the resulting gaps in 30-minute values were filled using estimated values. The estimation method depended on the gap length. Any gaps in $\mathrm{Q}_{\mathrm{e}}$ or $\mathrm{Q}_{\mathrm{h}}$ data occurring for less than 9 hours were filled by linear interpolation between values measured before and after the gap period. For larger gaps (table 3), the mean diurnal variation (MDV) method was applied. The MDV method replaces missing values with the average of measured values for the same half-hour period for the 7 days before and after the gap (Falge and others, 2001). Gaps in $\mathrm{Q}_{\mathrm{e}}$ and
$\mathrm{Q}_{\mathrm{h}}$ greater than a month were estimated by subtracting partial monthly means from full monthly means of adjacent data and then dividing by the count of missing data points. Installed instrumentation performed as expected, with typical amounts of missing data for these installations. Approximately 10.8 percent of the $\mathrm{Q}_{\mathrm{e}}$ data at Lake Mead and 7.9 percent of the $\mathrm{Q}_{\mathrm{h}}$ data at Lake Mohave were filtered and gap-filled over the period of record.

Thirty-minute averaged, filtered, and gap-filled evaporation rates were summed into daily, monthly, and annual evaporation-rate estimates for the period of record (May 2010 through May 2019). Thirty-minute evaporation rates and EC data collected at the EC stations are archived in the USGS National Water Information System database (U.S. Geological Survey, 2021), which can be accessed at https://waterdata .usgs.gov/nwis, using the U.S. Geological site identification numbers listed in table 2 .

\section{Evaporation from Lake Mead and Lake Mohave}

Evaporation for Lake Mead and Lake Mohave is calculated in 30-minute increments from latent-heat measurements, summed into monthly increments, and adjusted using annual energy balance data. Evaporation adjusted to force closure of the energy balance equation is summed into monthly and annual evaporation for each lake. Energy balance closure is necessary when turbulent fluxes and independently measured available energy are not equal at some determined time scale. The EBR is a commonly used metric to quantify energy balance closure. Energy balance ratios are unitless and are calculated as turbulent fluxes divided by available energy fluxes.

An EBR of 1 represents perfect energy balance. Wilson and others (2002) studied the results of several evaporation studies and reported an average annual EBR value of 0.80 , implying that on average 80 percent of available energy is accounted for by turbulent-energy measurement. The annual EBR is considered more accurate than monthly EBRs in this study because estimating monthly $\mathrm{Q}_{\mathrm{x}}$ and $\mathrm{Q}_{\mathrm{V}}$ in lakes as large, complex, and dynamic as Lake Mead and Lake Mohave is

Table 3. Turbulent flux and available energy data gaps at Lake Mead and Lake Mohave, Nevada and Arizona, 2015-18.

[Parameters: $Q_{e}$, latent-heat flux; $Q_{h}$, sensible-heat flux; $Q_{n}$, net radiation. Abbreviation: mm/dd/yyyy, month/day/year]

\begin{tabular}{|c|c|c|c|}
\hline From (mm/dd/yyyy) & To (mm/dd/yyyy) & Parameter established & Cause \\
\hline \multicolumn{4}{|c|}{ Lake Mead } \\
\hline $08 / 13 / 2015$ & $09 / 21 / 2015$ & $\mathrm{Q}_{\mathrm{e}}, \mathrm{Q}_{\mathrm{h}}$ & Station tipped over \\
\hline $07 / 20 / 2016$ & $09 / 07 / 2016$ & $\mathrm{Q}_{\mathrm{e}}$ & Krypton hygrometer failed \\
\hline \multicolumn{4}{|c|}{ Lake Mohave } \\
\hline $04 / 03 / 2017$ & $05 / 04 / 2017$ & $\mathrm{Q}_{\mathrm{e}}, \mathrm{Q}_{\mathrm{h}}, \mathrm{Q}_{\mathrm{n}}$ & Station tipped over \\
\hline $07 / 19 / 2018$ & $08 / 16 / 2018$ & $\mathrm{Q}_{\mathrm{e}}, \mathrm{Q}_{\mathrm{h}}, \mathrm{Q}_{\mathrm{n}}$ & Data download failure \\
\hline
\end{tabular}


subject to large uncertainties (Moreo and Swancar, 2013). Annual EBR values at Lake Mead ranged from 0.91 to 1.08, with a period of record mean of 0.98 (table 4). Annual EBR values at Lake Mohave ranged from 0.64 to 1.02 , with a period of record mean of 0.82 (table 5).

In this study, evaporation computed from measured $\mathrm{Q}_{\mathrm{e}}$ using EC was considered a probable minimum because measurements may have been affected by the adjacent desert. Probable maximum evaporation represents evaporation adjusted upwards for forced closure to satisfy the energy budget equation. A probable maximum was computed by adjusting measured annual turbulent fluxes using annual EBRs to achieve energy balance closure. Most probable evaporation represents the average between minimum and maximum evaporation and is used for all monthly calculations in this study.

\section{Monthly Estimates}

Monthly evaporation and summary statistics are presented in table 6 for Lake Mead and in table 7 for Lake Mohave. Evaporation estimates at both lakes are lowest in February and peak in August for Lake Mead (fig. 7A) and peak in September for Lake Mohave (fig. 7B). Monthly mean evaporation rates at Lake Mead are substantially greater than Lake Mohave from June through November (fig. 7C), which is attributable to a substantial difference in mean monthly available energy between the lakes.

\section{Available Energy}

There was a large difference in mean monthly available energy between the two lakes (fig. $8 A$ ). Available energy measurements at Lake Mead are mostly stable throughout the year while measurements at Lake Mohave rise sharply over the course of the summer and fall seasons. The range in monthly available energy at Lake Mead $\left(82-190 \mathrm{~W} / \mathrm{m}^{2}\right)$ was smaller than that measured at Lake Mohave $\left(17-262 \mathrm{~W} / \mathrm{m}^{2}\right)$. Available energy was greater at Lake Mead from January to September, and greater at Lake Mohave from October to December (fig. 8A).

Mean monthly $\mathrm{Q}_{\mathrm{n}}$ was similar at both lakes, following a typical sinusoidal, mid-latitude, northern hemisphere pattern with a peak in June and trough in December (fig. 8B). Summer $\mathrm{Q}_{\mathrm{n}}$ was slightly greater at the more northern Lake Mead, and winter $\mathrm{Q}_{\mathrm{n}}$ was slightly greater at the more southern Lake Mohave. Net radiation at both lakes was greater than at most land-based sites because the surface reflectivity of clear, open water is low. The dip in $Q_{n}$ at Lake Mohave in July and August is likely due to an underestimation of $\mathrm{Q}_{\mathrm{n}}$ during a period of missing data from July 19, 2018, to August 16, 2018 (table 3).

Net radiation provided most of the energy available for evaporative processes; however, changes in $Q_{x}$ and $Q_{v}$ were both important energy fluxes during this study. The depth of Lake Mead and the inflow temperature of Lake Mohave resulted in a notable seasonal lag in energy availability. Heat storage is usually near zero when averaged over a year (when the lake level is relatively constant) because energy moves into and out of storage through the seasons. Although mean annual $\mathrm{Q}_{\mathrm{x}}$ were similar and near zero for Lake Mead $\left(-2 \mathrm{~W} / \mathrm{m}^{2}\right)$ and

Table 4. Annual energy balance and summary statistics, Lake Mead, Nevada and Arizona, January 2011 through December 2018.

[Units: watts per square meter unless otherwise noted. Note: Annual change in stored heat $\left(Q_{x}\right)$ values for the years 2016 through 2018 represent periods of data that were estimated following the removal of the floating platforms and were not independently measured. Abbreviation: EBR, energy balance ratio]

\begin{tabular}{|c|c|c|c|c|c|c|c|c|c|}
\hline Year & $\begin{array}{c}\text { Net radia- } \\
\text { tion }\left(\mathbf{0}_{n}\right)\end{array}$ & $\begin{array}{c}\text { Change in } \\
\text { stored heat }\left(0_{x}\right)\end{array}$ & $\begin{array}{l}\text { Advected } \\
\text { heat }\left(0_{v}\right)\end{array}$ & $\begin{array}{l}\text { Latent-heat } \\
\text { flux }\left(\mathbf{0}_{\mathrm{e}}\right)\end{array}$ & $\begin{array}{c}\text { Sensible- } \\
\text { heat flux }\left(\mathbf{O}_{h}\right)\end{array}$ & $\begin{array}{c}\text { Available } \\
\text { energy }\end{array}$ & $\begin{array}{l}\text { Turbulent } \\
\text { flux }\end{array}$ & $\begin{array}{l}\text { EBR } \\
\text { (unit- } \\
\text { less) }\end{array}$ & $\begin{array}{l}\text { Bowen } \\
\text { ratio (unit- } \\
\text { less) }\end{array}$ \\
\hline 2011 & 137 & 32 & 34 & 138 & -7 & 139 & 131 & 0.94 & -0.05 \\
\hline 2012 & 133 & -9 & 0 & 139 & -9 & 142 & 130 & 0.91 & -0.07 \\
\hline 2013 & 126 & -9 & -2 & 133 & -4 & 134 & 130 & 0.97 & -0.03 \\
\hline 2014 & 130 & -7 & -1 & 143 & -12 & 135 & 131 & 0.97 & -0.08 \\
\hline 2015 & 131 & -8 & 2 & 154 & -7 & 141 & 147 & 1.05 & -0.05 \\
\hline 2016 & 130 & -2 & 6 & 159 & -10 & 138 & 149 & 1.08 & -0.06 \\
\hline 2017 & 131 & -6 & 6 & 149 & -11 & 142 & 138 & 0.97 & -0.07 \\
\hline 2018 & 128 & -6 & 3 & 146 & -13 & 137 & 133 & 0.97 & -0.09 \\
\hline \multicolumn{10}{|c|}{ Period of record summary statistics } \\
\hline Mean & 131 & -2 & 6 & 145 & -9 & 138 & 136 & 0.98 & -0.06 \\
\hline $\begin{array}{l}\text { Standard } \\
\text { deviation }\end{array}$ & 3 & 14 & 12 & 9 & 3 & 8 & 8 & 0.05 & 0.02 \\
\hline Maximum & 137 & 32 & 34 & 159 & -4 & 142 & 149 & 1.08 & -0.03 \\
\hline Minimum & 126 & -9 & -2 & 133 & -13 & 134 & 130 & 0.91 & -0.09 \\
\hline
\end{tabular}


Table 5. Annual energy balance and summary statistics, Lake Mohave, Nevada and Arizona, January 2014 through December 2018.

[Units: watts per square meter unless otherwise noted. Note: Annual change in stored heat $\left(\mathrm{Q}_{\mathrm{x}}\right)$ values for the years 2016 through 2018 represent periods of data that were estimated following the removal of the floating platforms and were not independently measured. Abbreviation: EBR, energy balance ratio]

\begin{tabular}{|c|c|c|c|c|c|c|c|c|c|}
\hline Year & $\begin{array}{l}\text { Net radia- } \\
\text { tion }\left(\mathbf{Q}_{n}\right)\end{array}$ & $\begin{array}{c}\text { Change in } \\
\text { stored heat }\left(0_{x}\right)\end{array}$ & $\begin{array}{l}\text { Advected } \\
\text { heat }\left(0_{v}\right)\end{array}$ & $\begin{array}{l}\text { Latent-heat } \\
\text { flux }\left(\mathbf{0}_{\mathrm{e}}\right)\end{array}$ & $\begin{array}{c}\text { Sensible- } \\
\text { heat flux }\left(0_{h}\right)\end{array}$ & $\begin{array}{l}\text { Available } \\
\text { energy }\end{array}$ & $\begin{array}{l}\text { Turbulent } \\
\text { flux }\end{array}$ & $\begin{array}{c}\text { EBR } \\
\text { (unit- } \\
\text { less) }\end{array}$ & $\begin{array}{c}\text { Bowen ratio } \\
\text { (unitless) }\end{array}$ \\
\hline 2014 & 125 & 4 & -19 & 117 & -25 & 102 & 92 & 0.89 & -0.22 \\
\hline 2015 & 132 & -7 & -13 & 109 & -21 & 126 & 89 & 0.7 & -0.19 \\
\hline 2016 & 139 & 0 & -10 & 105 & -22 & 130 & 83 & 0.64 & -0.21 \\
\hline 2017 & 134 & 1 & -11 & 132 & -28 & 122 & 104 & 0.85 & -0.21 \\
\hline \multicolumn{10}{|c|}{ Period of record summary statistics } \\
\hline Mean & 129 & 0 & -13 & 119 & -25 & 116 & 94 & 0.82 & -0.21 \\
\hline $\begin{array}{l}\text { Standard } \\
\text { deviation }\end{array}$ & 10 & 4 & 3 & 13 & 4 & 14 & 9 & 0.15 & 0.01 \\
\hline
\end{tabular}

Table 6. Monthly evaporation and summary statistics, Lake Mead, Nevada and Arizona, March 2010 through April 2019.

[Units: millimeters, mm. Abbreviation: - , no data]

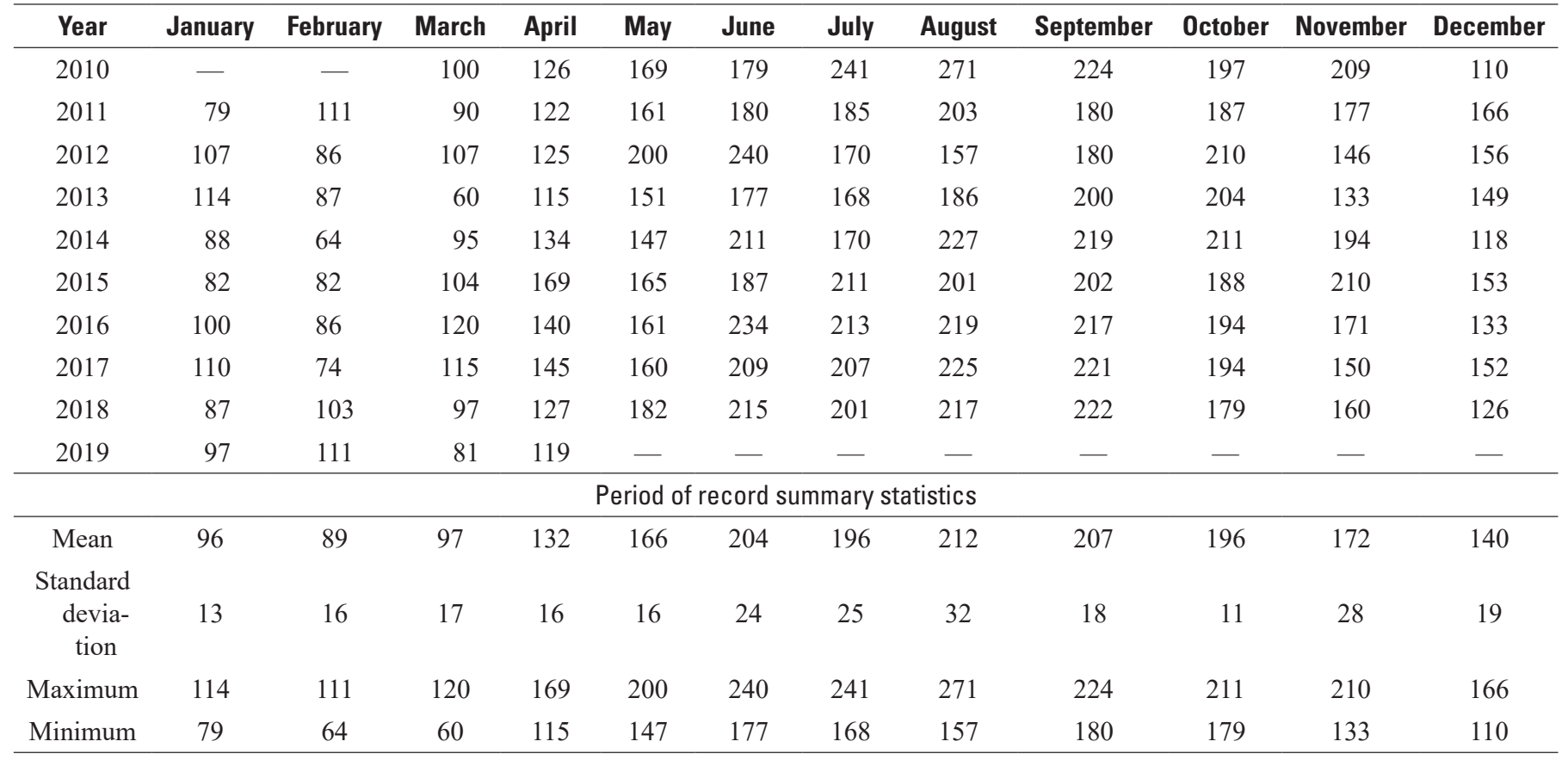

Lake Mohave $\left(0 \mathrm{~W} / \mathrm{m}^{2}\right)$, monthly ranges of $\mathrm{Q}_{\mathrm{x}}$ indicate a wider range between the two lakes. The mean monthly change in heat storage was more positive at Lake Mohave during the first half of the year (more energy going into storage) and more negative during the second half of the year than Lake Mead (more energy coming out of storage; fig. 8C). This difference between the lakes is driven by depth. Deep lakes will have greater $Q_{x}$ than shallow lakes because the thicker water column can store more energy; therefore, lake depth has a substantial effect on seasonal evaporation patterns (Sacks and others, 1994; Blanken and others, 2003; Finch and Hall, 2005).

However, the primary component behind the difference in seasonal available energy between Lake Mead and Lake Mohave is $\mathrm{Q}_{\mathrm{v}}$. Advected heat at Lake Mead is lower in the winter months (November-April), while $\mathrm{Q}_{\mathrm{V}}$ is lower at Lake Mohave during the summer months (May-October; fig. 8D). 
Table 7. Monthly evaporation and summary statistics, Lake Mohave, Nevada and Arizona, May 2013 through April 2019.

[Units: millimeters, mm. Abbreviation: —, no data]

\begin{tabular}{|c|c|c|c|c|c|c|c|c|c|c|c|c|}
\hline Year & January & February & March & April & May & June & July & August & September & October & November & December \\
\hline 2013 & - & - & - & - & 145 & 166 & 128 & 170 & 181 & 188 & 105 & 158 \\
\hline 2014 & 107 & 65 & 123 & 144 & 152 & 158 & 137 & 157 & 150 & 163 & 151 & 94 \\
\hline 2015 & 90 & 81 & 114 & 172 & 145 & 129 & 165 & 165 & 156 & 149 & 202 & 144 \\
\hline 2016 & 87 & 115 & 126 & 131 & 148 & 131 & 109 & 167 & 194 & 169 & 172 & 186 \\
\hline 2017 & 115 & 49 & 99 & 118 & 185 & 178 & 168 & 207 & 255 & 172 & 124 & 191 \\
\hline 2018 & 103 & 110 & 102 & 147 & 172 & 165 & 118 & 175 & 175 & 160 & 141 & 109 \\
\hline 2019 & 101 & 97 & 106 & 126 & - & - & - & - & - & - & - & - \\
\hline \multicolumn{13}{|c|}{ Period of record summary statistics } \\
\hline Mean & 101 & 86 & 112 & 140 & 158 & 155 & 138 & 174 & 185 & 167 & 149 & 147 \\
\hline $\begin{array}{c}\text { Standard } \\
\text { devia- } \\
\text { tion }\end{array}$ & 39 & 40 & 43 & 56 & 17 & 20 & 24 & 18 & 38 & 13 & 35 & 40 \\
\hline Maximum & 115 & 115 & 126 & 172 & 185 & 178 & 168 & 207 & 255 & 188 & 202 & 191 \\
\hline Minimum & 87 & 49 & 99 & 118 & 145 & 129 & 109 & 157 & 150 & 149 & 105 & 94 \\
\hline
\end{tabular}

Differences in $\mathrm{Q}_{\mathrm{v}}$ between Lake Mead and Lake Mohave are due to differences in inflow and outflow water temperatures. Lake Mead inflow temperatures from the Colorado River are warmer over the course of a year, particularly during summer months, than outflow from Hoover Dam, resulting in positive $Q_{v}$ (fig. 9). Lake Mohave inflow, released from Hoover Dam, includes cool water from deep in the water profile. Lake Mohave outflow, released from near the surface at Davis Dam, is much warmer than inflow. This temperature difference at Lake Mohave results in a persistent loss of energy (negative $\mathrm{Q}_{\mathrm{v}}$ ), resulting in less energy available for evaporation.

\section{Water-Temperature Profiles}

Water-temperature profiles were measured from the floating platforms at Lake Mead and Lake Mohave as part of the water-quality monitoring study (Veley and Moran, 2012). Lake Mead had a maximum sampling depth of $80 \mathrm{~m}$ at the floating platform (fig. 10A) and Lake Mohave had a maximum sampling depth of $28.5 \mathrm{~m}$ (fig. 10B). The thicker water column at Lake Mead allows for more energy storage, as evidenced by the pronounced thermocline and near constant low temperatures at the greater depths. The depth of Lake Mead allows it to store energy, effectively moderating fluctuating thermal conditions in the lake. In contrast, the shallower Lake Mohave reacts faster to changes in thermal conditions than Lake Mead. The shallow thermocline rapidly develops and advances at Lake Mohave beginning in June (correlating with peak $Q_{n}$ ), and the epilimnion, or the top layer of a thermally stratified lake, is most pronounced during the hot months of July-October. Because $Q_{s}$ penetrates the full depth of Lake Mohave more thoroughly than Lake Mead, seasonal temperatures at depth warm and cool much more than Lake Mead. Maximum near-surface temperatures at both lakes occur in
August (correlated to maximum air temperature), while minimum near-surface temperatures occur in January-February for Lake Mohave and February-March for Lake Mead. Lake Mead temperatures are higher over the winter because it takes additional time to cool its thicker water column than Lake Mohave.

Evaporation is mostly correlated with $\mathrm{Q}_{\mathrm{n}}$, but this relation is weaker with deeper lakes than shallow lakes (Moreo and Swancar, 2013). In deep lakes, a greater proportion of the $Q_{n}$ goes to warming the deeper water column in the first half of the year when the lake is still cold, and therefore not as much $\mathrm{Q}_{\mathrm{n}}$ is available to drive evaporation. In the fall, the opposite is true for deep lakes; more energy is released from deep storage during the second half of the year, which helps drive evaporation even though $Q_{n}$ is decreasing. The deeper Lake Mead has a greater thermal mass and thus maintains stored heat per unit area better than Lake Mohave (fig. 8C).

\section{Inflow and Outflow Water Temperatures}

Temperatures of water flowing into Lake Mead are based on upstream Colorado River temperatures and follow a seasonal pattern, which generally is highest temperatures measured in July and lowest temperatures measured in January (fig. 11). Lake Mead monthly average inflow temperatures ranged from 8.4 to $19.4{ }^{\circ} \mathrm{C}$ over the period of record (fig. 11). Lake Mead outflow water temperatures at Hoover Dam are assumed to be the same as Lake Mohave inflow temperatures; these peak in November and have less variation throughout the year, ranging only 4.5 degrees over the period of record (12.1-16.8 ${ }^{\circ} \mathrm{C}$; fig. 11). Lake Mohave outflow temperatures at Davis Dam peak in September and ranged from 10.4 to 21.8 ${ }^{\circ} \mathrm{C}$ over the period of record. For most of the year (March through November) Lake Mohave outflow temperatures are 
$A$

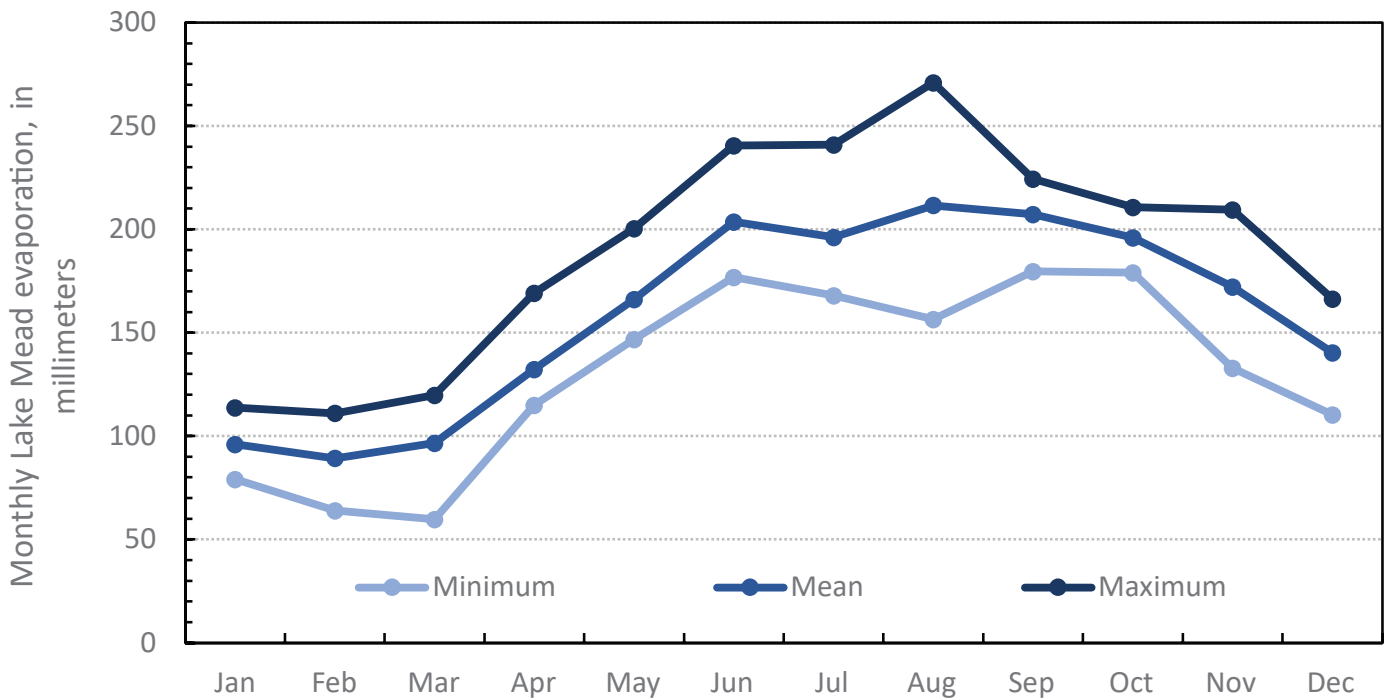

$B$

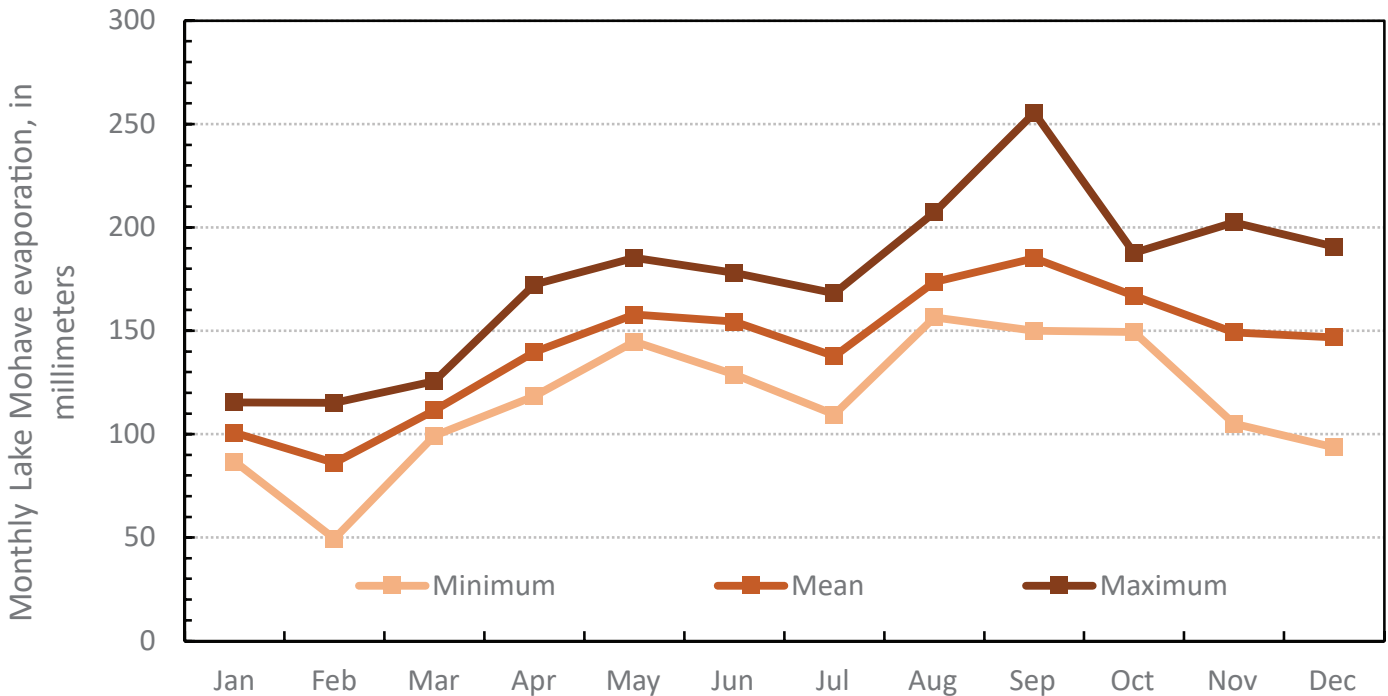

C

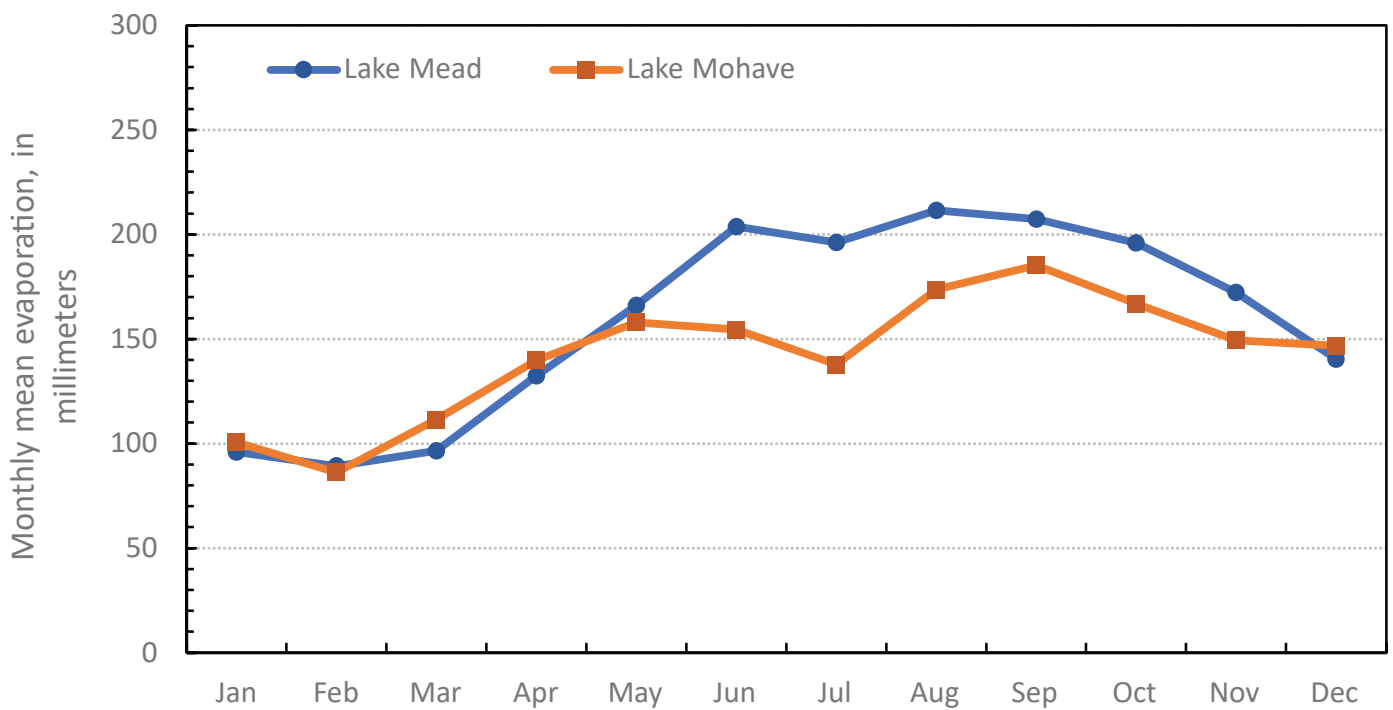

Figure 7. Monthly minimum, mean, and maximum evaporation at $A$, Lake Mead, Nevada and Arizona, March 2010 through April 2019 and B, Lake Mohave, Nevada and Arizona, May 2013 through April 2019; and C, monthly mean evaporation at Lake Mead and Lake Mohave, Nevada and Arizona, May 2013 through April 2019. 

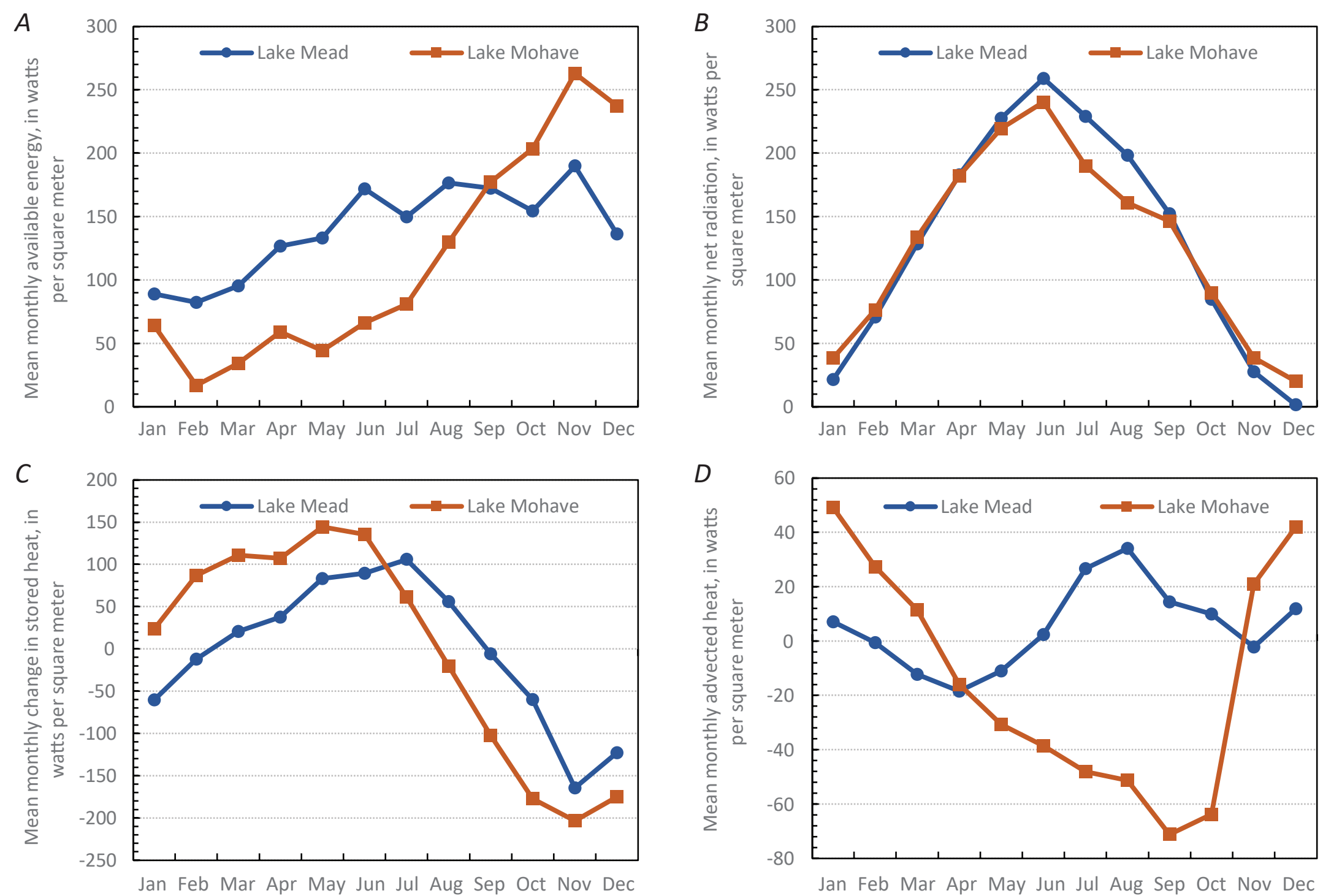

Figure 8. Mean monthly $A$, available energy, $B$, net radiation, $C$, change in stored heat, and $D$, advected heat, Lake Mead and Lake Mohave, Nevada and Arizona, May 2013 through April 2019 


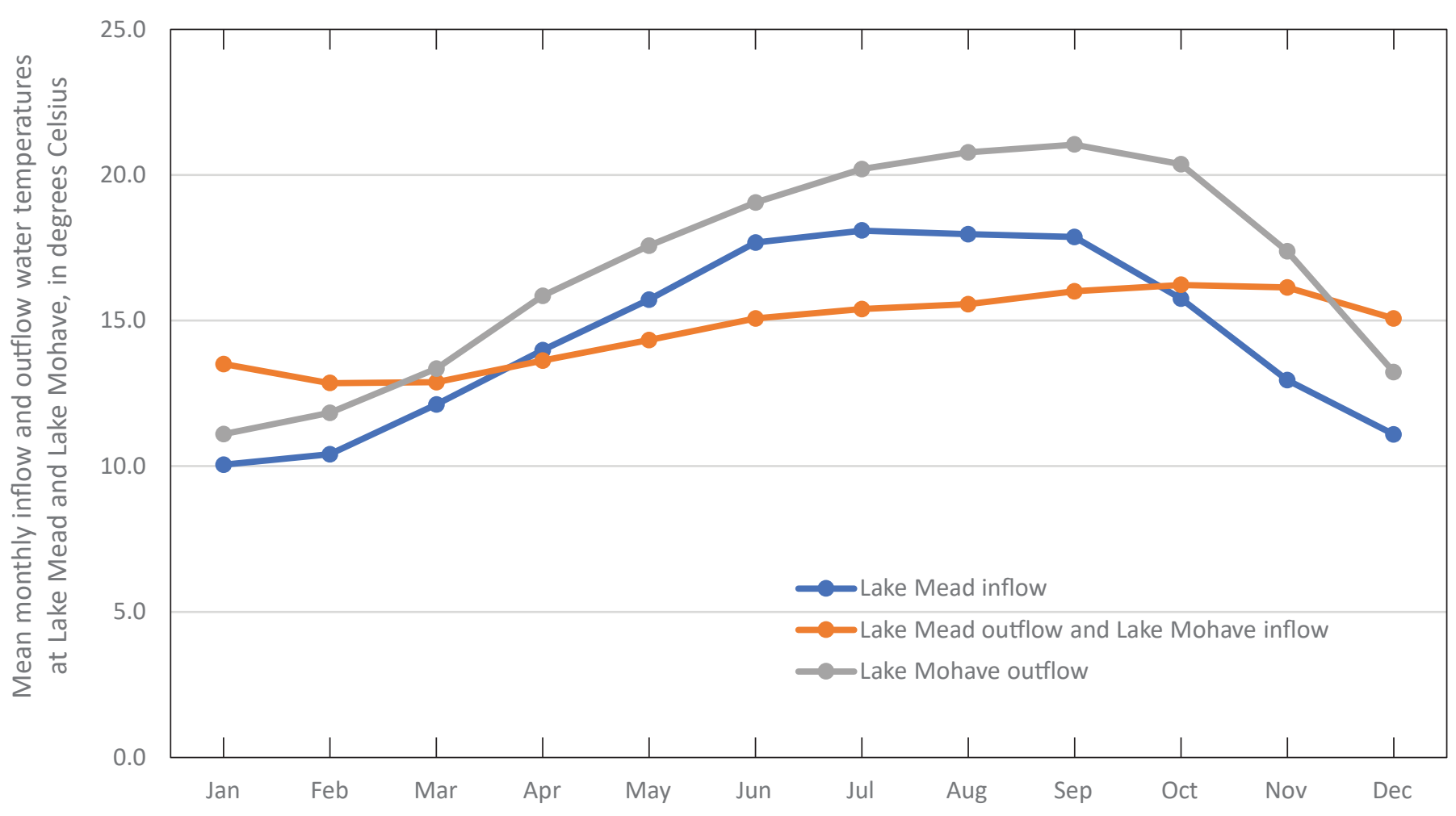

Figure 9. Mean monthly inflow and outflow water temperatures at Lake Mead and Lake Mohave, Nevada and Arizona, May 2013 through April 2019. 
A
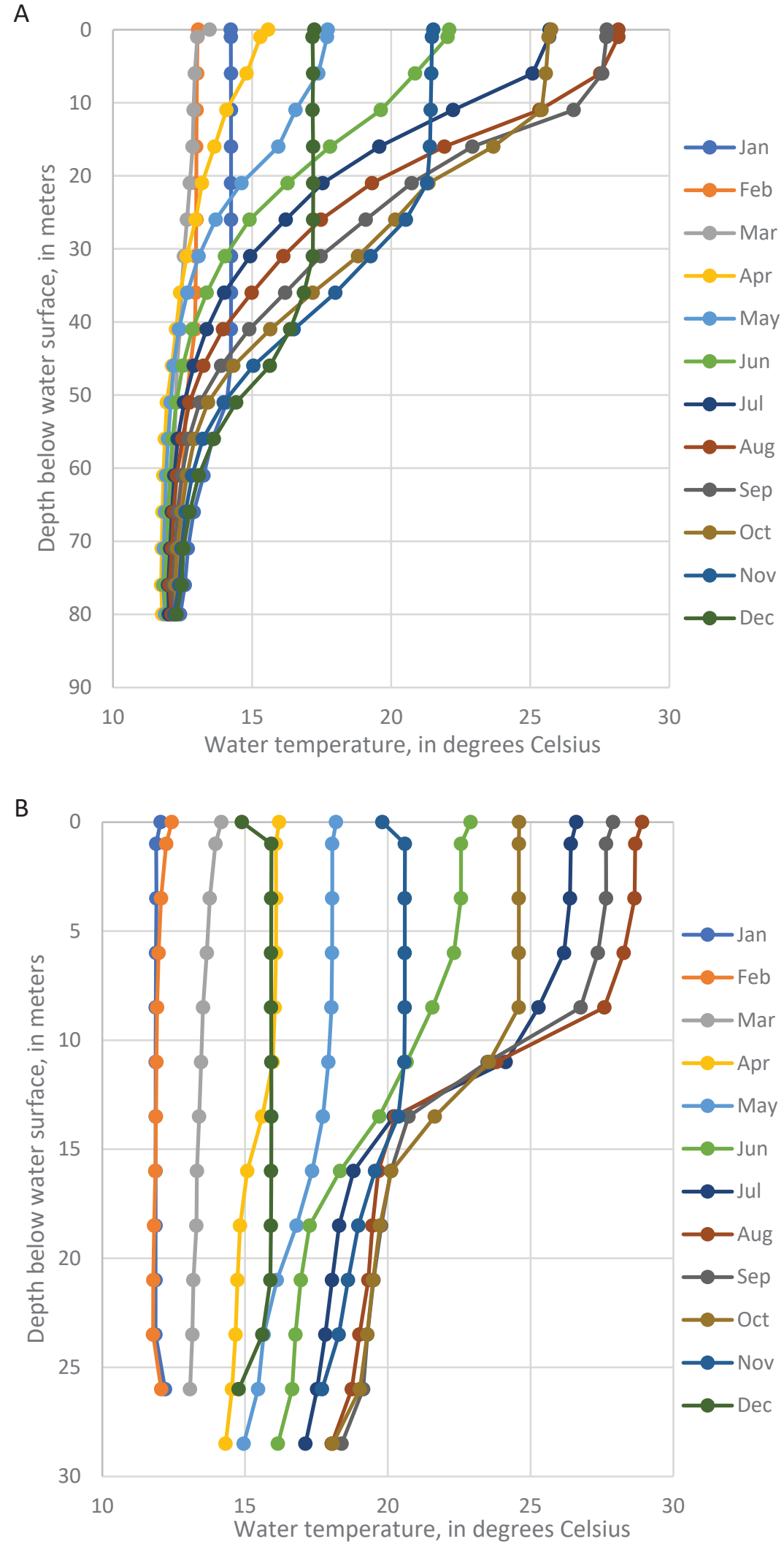

Figure 10. Mean water-temperature profiles by depth at $A$, Lake Mead, Nevada and Arizona, March 2010 through October 2016; and at B, Lake Mohave, Nevada and Arizona, May 2013 through October 2016. 


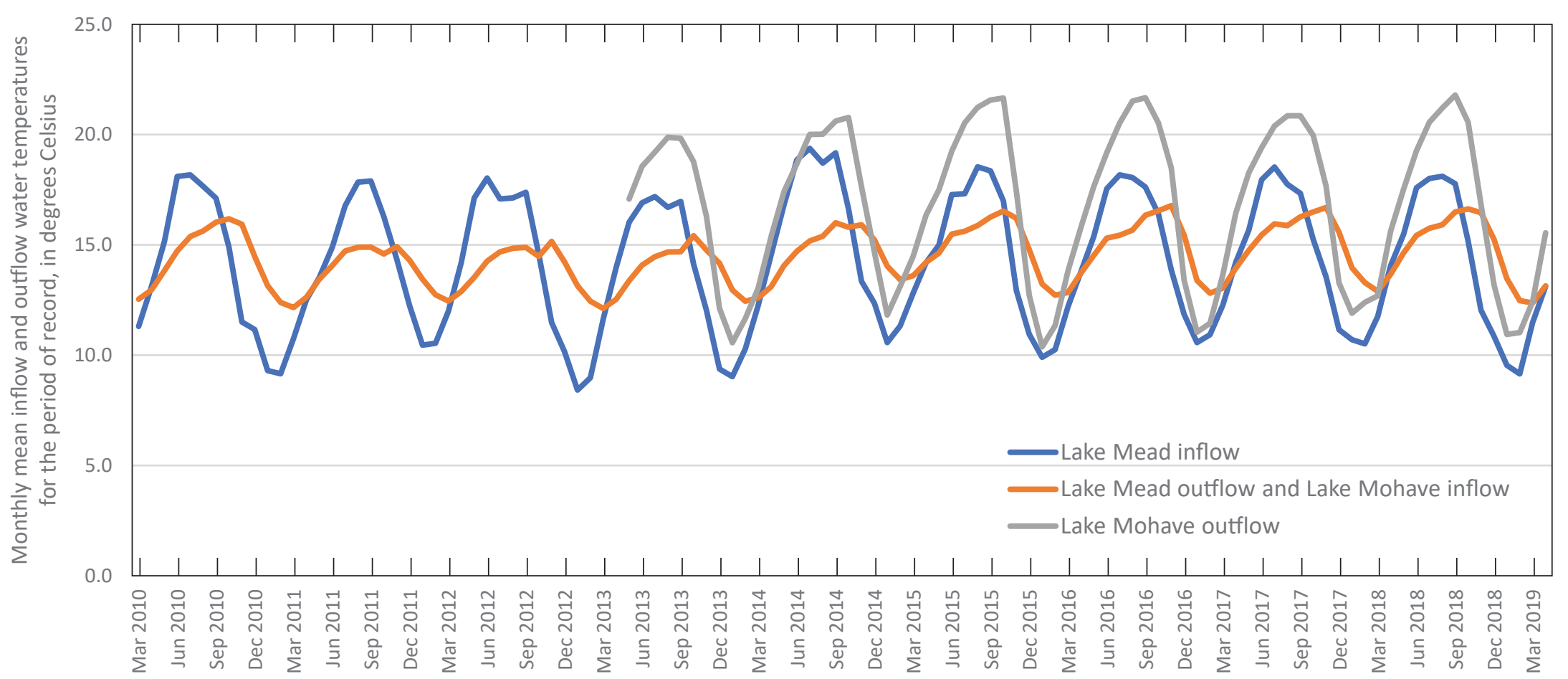

Figure 11. Monthly mean inflow and outflow water temperatures at Lake Mead, Nevada and Arizona, March 2010 through April 2019, and Lake Mohave, Nevada and Arizona, May 2013 through April 2019. 
higher than inflow temperatures, indicating that the water gains heat between Hoover Dam and Davis Dam. From December through February, the opposite is true; the water is cooled between the dams because inflow temperatures are higher than outflow temperatures. At Lake Mead, the year is split evenly; from April through September, the outflow temperatures are cooler than the inflow temperatures, and from October through March, the inflow temperatures are cooler than the outflow temperatures.

\section{Turbulent Fluxes}

Monthly turbulent fluxes mostly increase seasonally from lows in February and March at both lakes to peaks in September for Lake Mohave and in September-November for Lake Mead (fig. 12A). Monthly $\mathrm{Q}_{\mathrm{e}}$ peaks in September for both Lake Mead and Lake Mohave (fig. 12B). Monthly $\mathrm{Q}_{\mathrm{h}}$ is most negative in June for both lakes, reflecting the greatest difference between the hot summer air and the cold lakes, and is most positive in December (fig. 12C). Negative $Q_{h}$ indicates that the water "extracts" energy from the air. The negative sign indicates a net downward flux of sensible-heat energy into the lake. Mean monthly $Q_{h}$ was negative or zero for the entire period of record at Lake Mohave and is a result of the year-round cold-water advection into the lake from Lake Mead.

Annual Bowen ratios at Lake Mead ranged from -0.09 to -0.03 and the period of record mean was -0.06 (table 4 ). Annual Bowen ratios at Lake Mohave ranged from -0.22 to -0.19 , and the period of record mean was -0.21 (table 5). The Bowen ratio will be negative if $\mathrm{Q}_{\mathrm{h}}$ is negative (fig. 12D), which can happen when the lake surface is colder than the air. The mean annual Bowen ratio at Lake Mead of -0.06 is close to zero, indicating that fluctuations of sensible heat tend to cancel out over the course of a year and $Q_{e}$ measurements need little adjustment when it is balanced to the energy budget. The mean annual Bowen ratio at Lake Mohave of -0.21 indicates that $\mathrm{Q}_{\mathrm{e}}$ (evaporation) must be more heavily adjusted when it is balanced to the energy budget.

\section{Annual Available Energy}

Annual available energy at Lake Mead was consistently greater than at Lake Mohave (fig. 13A). The period of record mean annual available energy was $138 \mathrm{~W} / \mathrm{m}^{2}$ at Lake Mead, an 18 percent difference from the mean annual available energy of $116 \mathrm{~W} / \mathrm{m}^{2}$ at Lake Mohave (tables 4 and 5). This difference is substantial and has important implications for evaporation-rate estimates.

The primary driver of annual available energy differences between the two lakes was $\mathrm{Q}_{\mathrm{v}}$. Annual $\mathrm{Q}_{\mathrm{n}}$ (fig. 13B) was similar at the two lakes. The period of record mean annual $\mathrm{Q}_{\mathrm{n}}$ was $131 \mathrm{~W} / \mathrm{m}^{2}$ at Lake Mead and $129 \mathrm{~W} / \mathrm{m}^{2}$ at Lake Mohave. Annual changes in stored heat were similar for the two lakes during the 3 years of overlapping independent record, 2014-16. The annual change in stored heat ranged from -9 to $32 \mathrm{~W} / \mathrm{m}^{2}$ at Lake Mead and from -7 to $4 \mathrm{~W} /$ $\mathrm{m}^{2}$ at Lake Mohave over the course of this study (fig. 13C). Mean annual $\mathrm{Q}_{\mathrm{v}}$ was $-13 \mathrm{~W} / \mathrm{m}^{2}$ at Lake Mohave compared to $2 \mathrm{~W} / \mathrm{m}^{2}$ at Lake Mead for the same period (January 2013December 2018; fig. 13D). The inflow/outflow temperature difference at Lake Mohave results in a persistent loss of energy (negative $Q_{v}$ ) as more energy is used to heat the lake, resulting in less energy available for evaporation.

\section{Annual Turbulent Fluxes}

Annual turbulent fluxes at Lake Mead were consistently greater than at Lake Mohave (fig. 14A). This was due to a combination of greater $\mathrm{Q}_{\mathrm{e}}$ at Lake Mead (fig. 14B) and more negative $\mathrm{Q}_{\mathrm{h}}$ at Lake Mohave (fig. 14C). Annual EBRs were greater at Lake Mead than at Lake Mohave, indicating less uncertainty at Lake Mead compared to Lake Mohave due to better energy balance closure (fig. 14D).

Evaporation is proportional to vapor pressure difference, as described in Moreo and Swancar (2013). Vapor pressure difference was computed at the floating platforms as an independent check on EC measurements. Mean monthly vapor pressure difference was computed from data collected at the floating platforms at Lake Mead and Lake Mohave from May 2013 through September 2016 (fig. 15). Mean monthly vapor pressure differences magnitudes between Lake Mead and Lake Mohave compare generally to EC based evaporation-rate estimates (fig. $7 C$ ), with similar seasonal patterns.

\section{Uncertainty Analysis and Limitations}

Uncertainties in monthly and annual available energy and EC measurements are quantified according to Moreo and Swancar (2013). There are no formal USGS standards, nor is there a reliable method to evaluate the quality and accuracy of an ET data record. With respect to the completeness, given the small amount of estimated data, the records at both lakes are considered very good. The differences between minimum and most probable annual evaporation (which can be considered a surrogate for uncertainty) at Lake Mead are small, ranging from 25 to $86 \mathrm{~mm}$ ( 0.98 to $3.39 \mathrm{in}$.) over the period of record, or 1-5 percent of the annual evaporation (fig. 16A). At Lake Mohave, the difference is greater, ranging from 16 to $383 \mathrm{~mm}$ (0.63 to 15.08 in.) or 1-22 percent of annual evaporation (fig. 16B). The differences at Lake Mohave are most pronounced in 2015-16. The large spread in evaporation estimates in 2015-16 parallel periods of low turbulent fluxes measured at Lake Mohave, especially during the summer months when turbulent flux is typically highest.

The EBR is often used to evaluate the performance of an EC system. Energy imbalances are expected to be greater if a significant proportion of measured turbulent fluxes originated from the desert surrounding the lake, which is possibly the case at Lake Mohave. Available energy at the desert surface is less than at the lake surface because the lighter-colored desert surface reflects a greater amount of incoming shortwave 


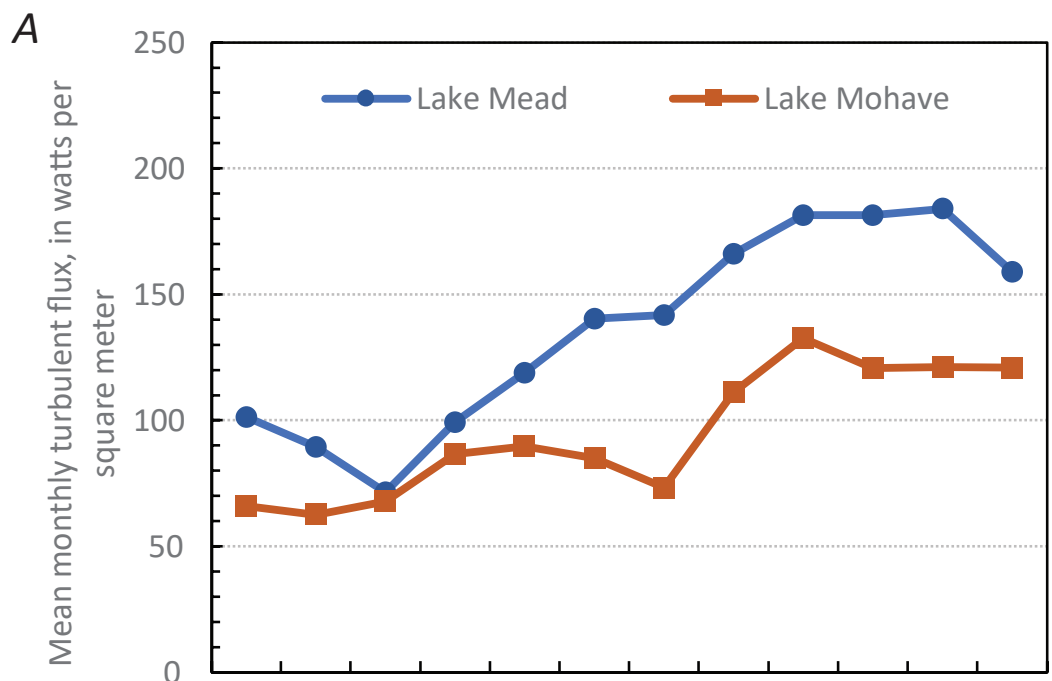

Jan Feb Mar Apr May Jun Jul Aug Sep Oct Nov Dec

C

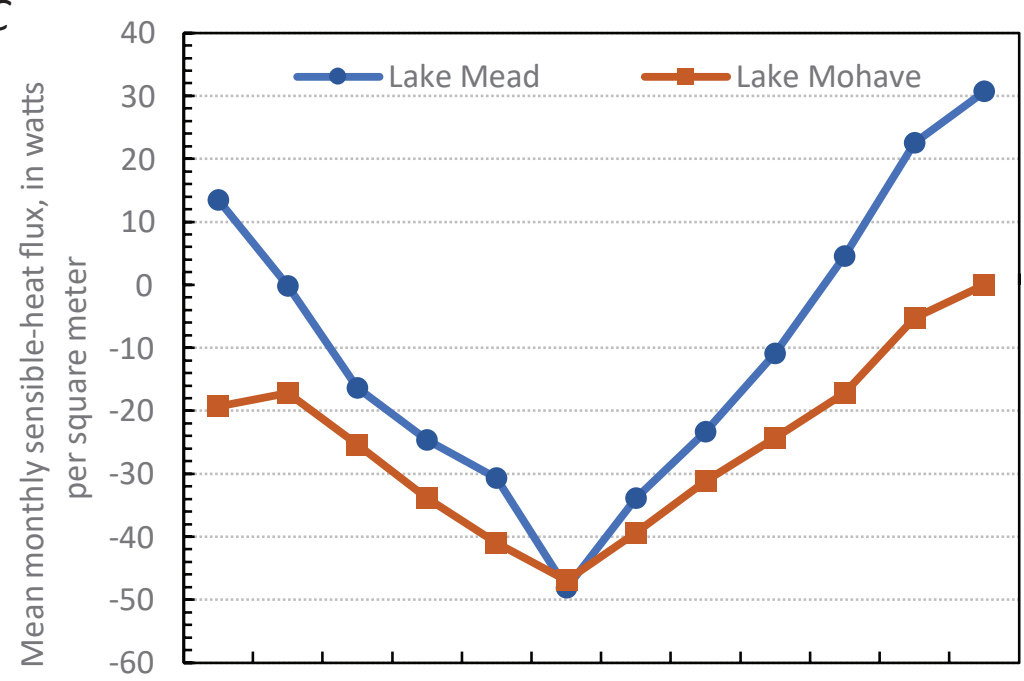

Jan Feb Mar Apr May Jun Jul Aug Sep Oct Nov Dec
$B$

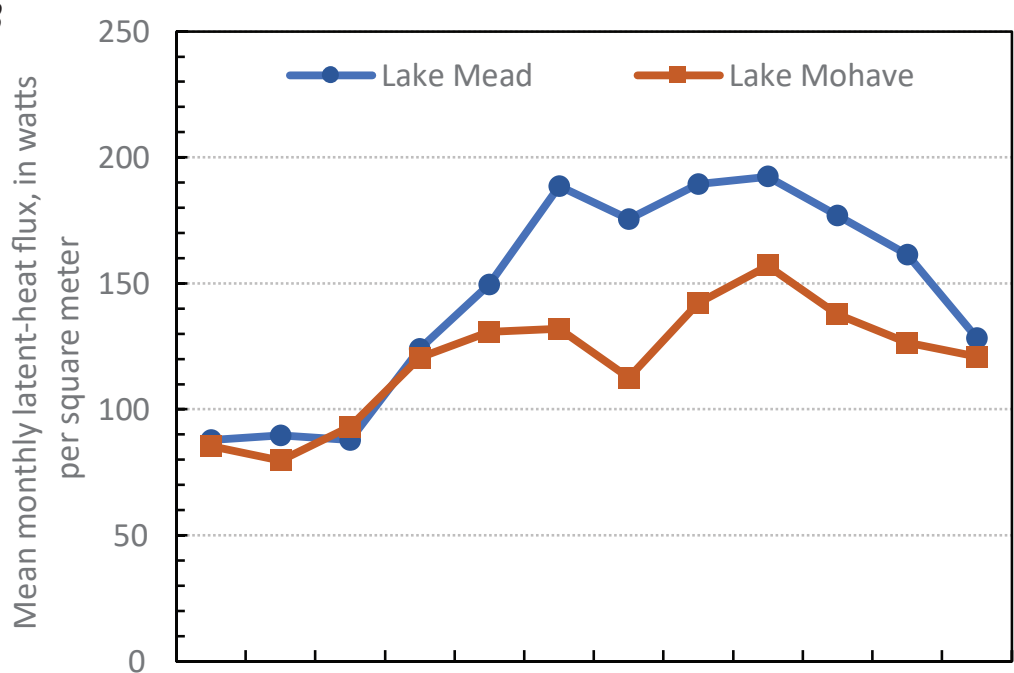

Jan Feb Mar Apr May Jun Jul Aug Sep Oct Nov Dec

$D$

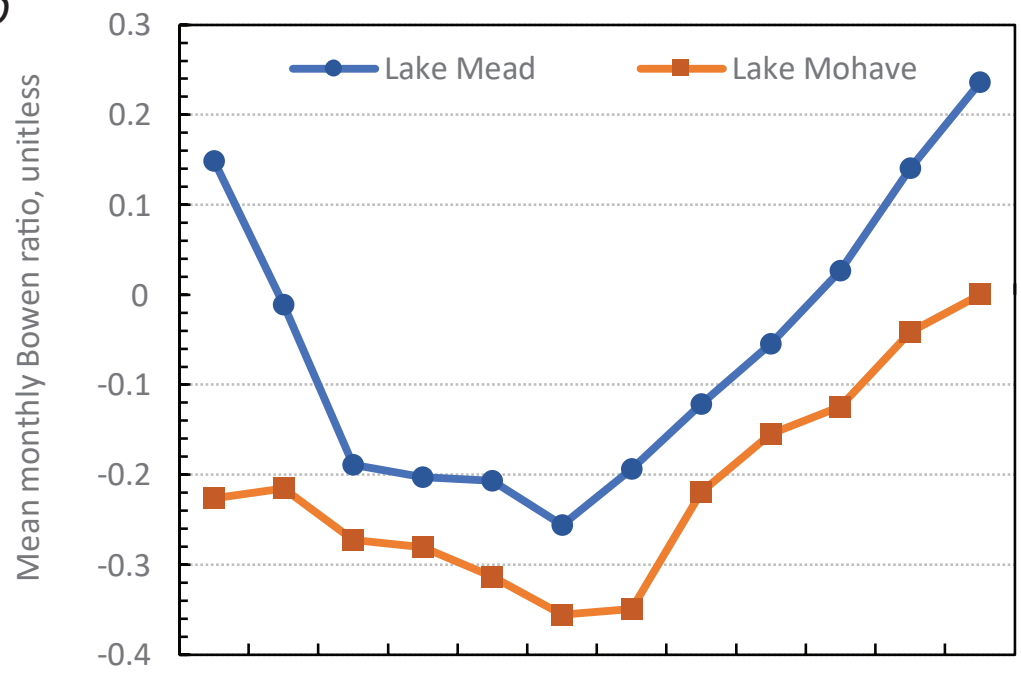

Jan Feb Mar Apr May Jun Jul Aug Sep Oct Nov Dec
ธั

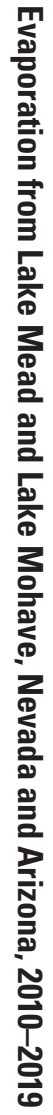

Figure 12. Mean monthly $A$, turbulent flux, $B$, latent-heat flux, $C$, sensible-heat flux, and $D$, Bowen ratio, Lake Mead and Lake Mohave, Nevada and Arizona, May 2013 through April 2019 

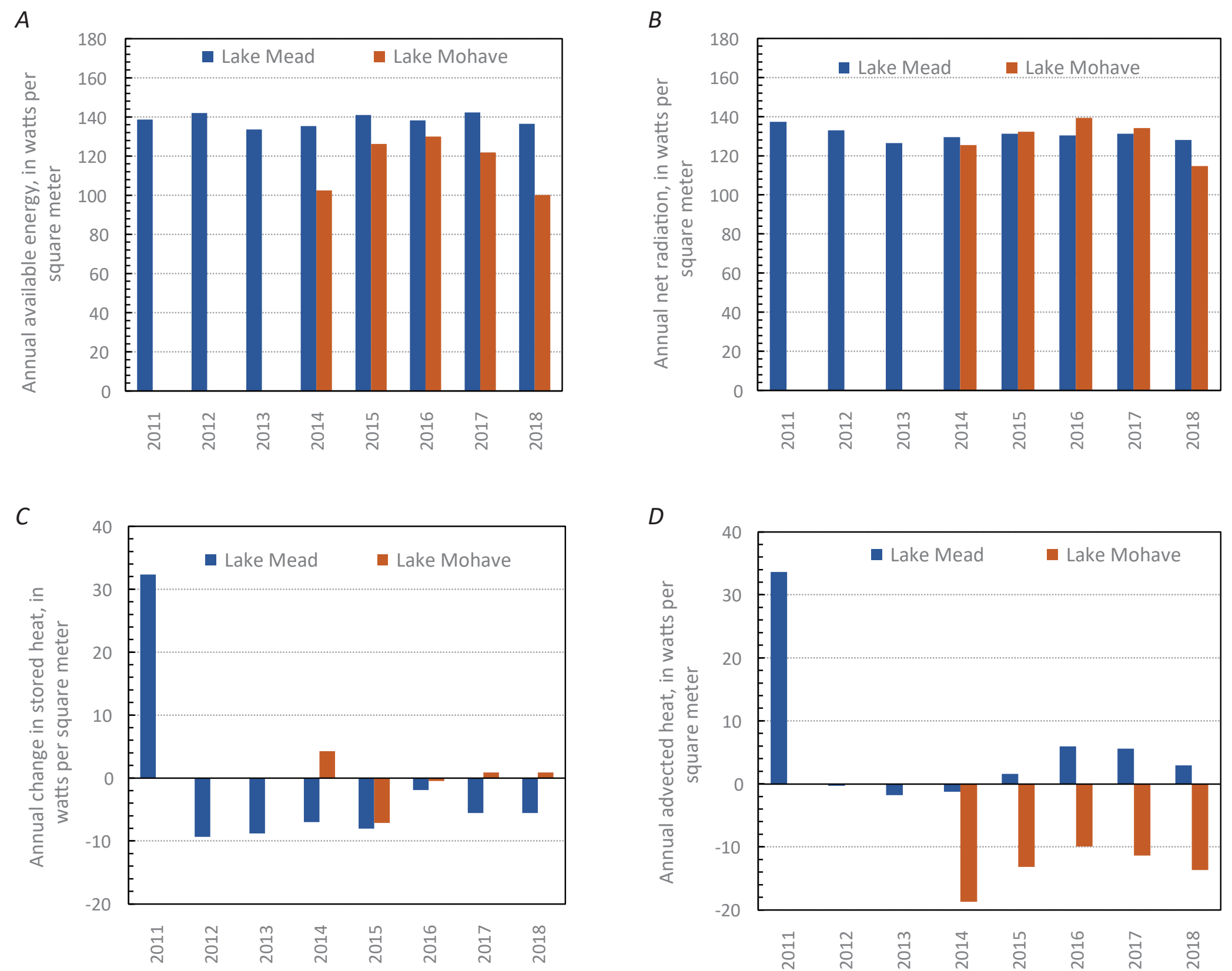

Figure 13. Annual $A$, available energy, $B$, net radiation, $C$, change in stored heat, and $D$, advected heat, Lake Mead and Lake Mohave, Nevada and Arizona, May 2010 through April 2019. 

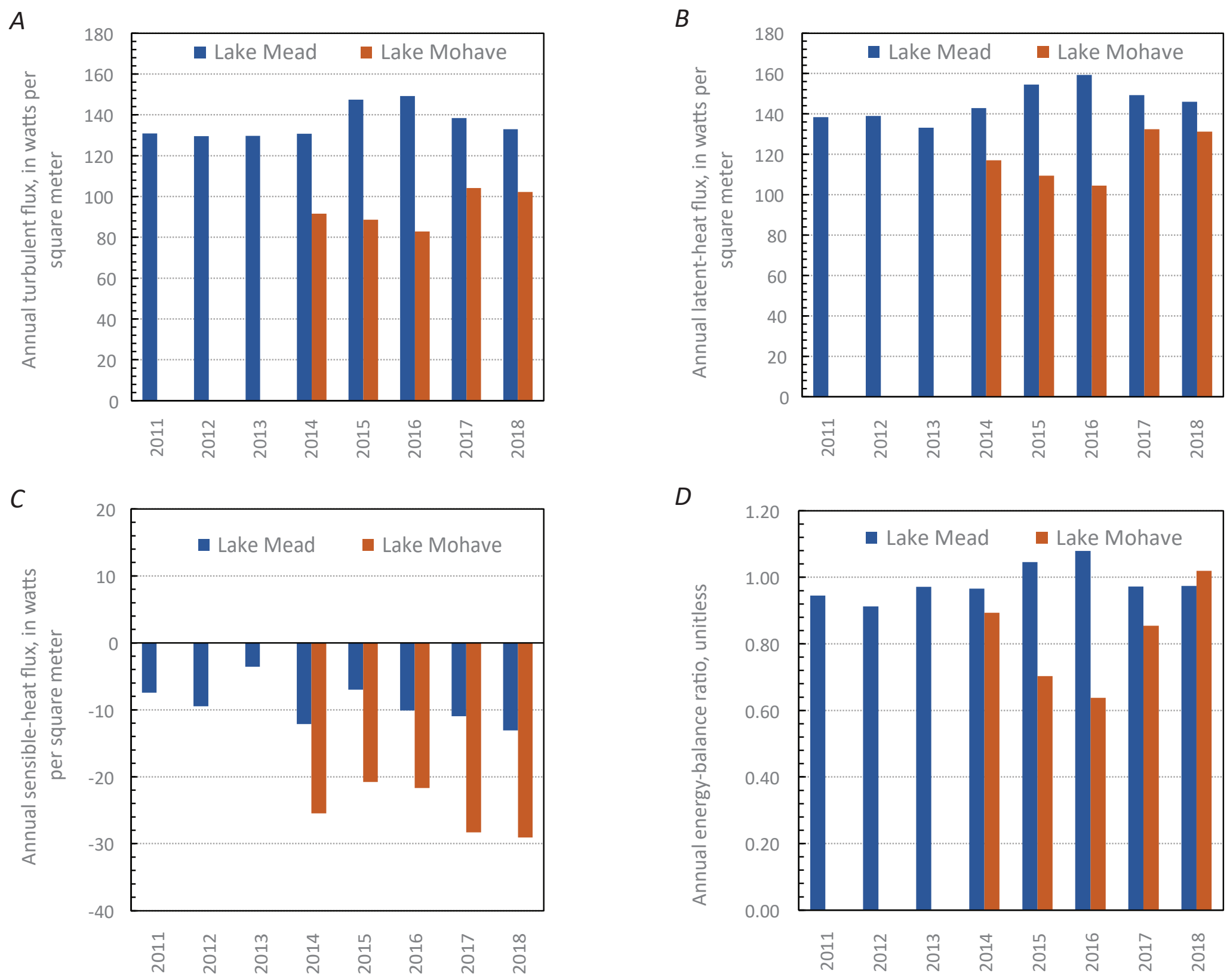

๘

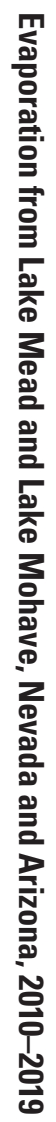

Figure 14. Annual $A$, turbulent flux, $B$, latent-heat flux, $C$, sensible-heat flux, and $D$, energy-balance ratio, Lake Mead and Lake Mohave, Nevada and Arizona, May 2010 through April 2019. 


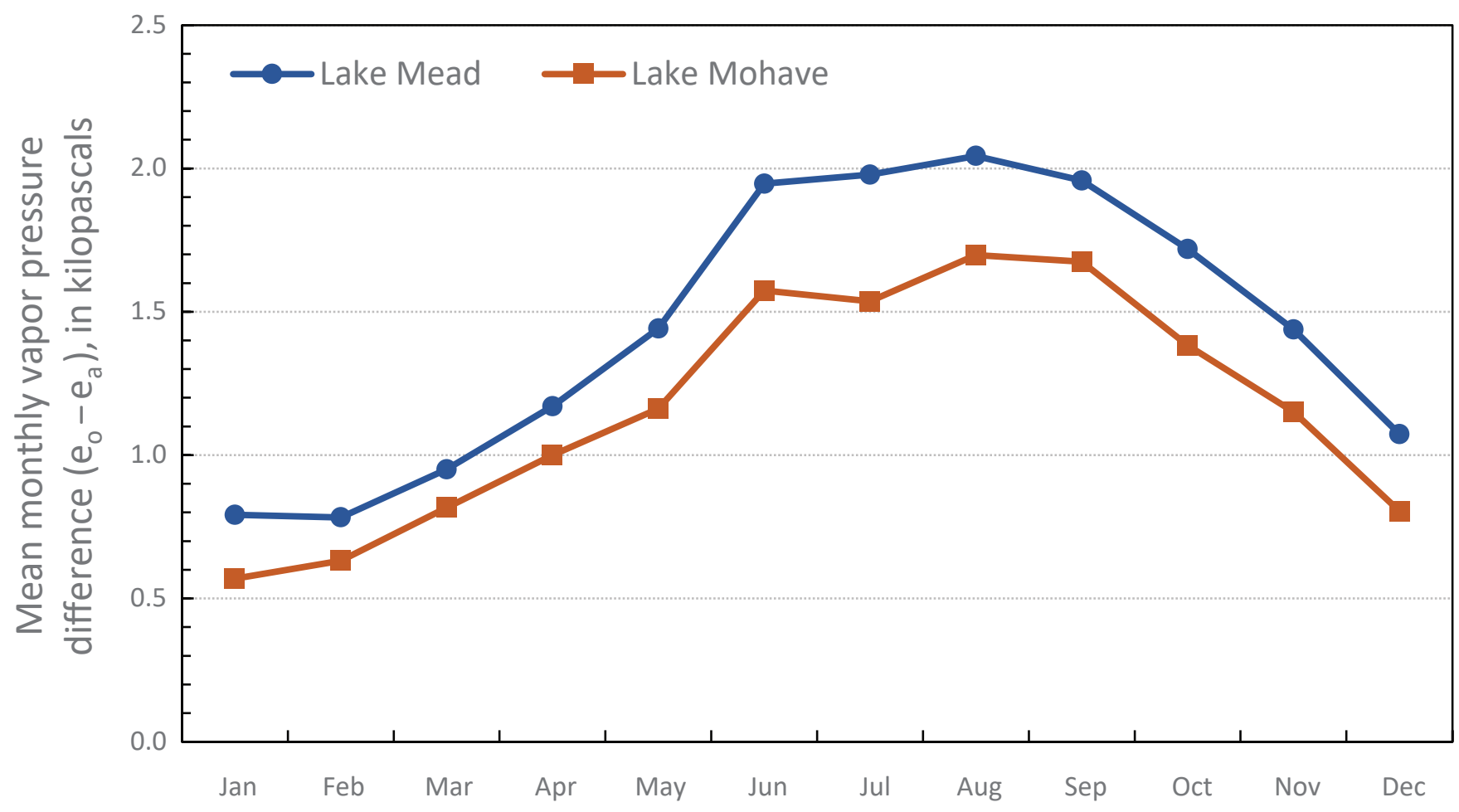

Figure 15. Mean monthly vapor pressure difference at Lake Mead and Lake Mohave, Nevada and Arizona, May 2013 through April 2019.

radiation back to the atmosphere. Furthermore, if the adjacent desert had a significant effect on the energy balance, then a higher Bowen ratio (due to less water vapor) would be evident, as is the case at Lake Mohave. The mean annual EBR of 0.98 and a standard deviation of 0.05 at Lake Mead indicates that 98 percent of estimated available energy was accounted for by turbulent energy flux (table 4). A Bowen ratio of -0.06 at Lake Mead supports the source-area analysis conclusion that EC fluxes are representative of open water and that any impact on flux measurements by the desert surface was minimal. This is less true at Lake Mohave, where a mean annual EBR of 0.82 and a standard deviation of 0.15 indicates that 82 percent of estimated available energy was accounted for by turbulent energy flux (table 5). A mean annual Bowen ratio of -0.21 at Lake Mohave indicates that the desert surface may have had some impact on flux measurements.

Additional uncertainties arose when the platforms and associated available energy sensors were removed from service in 2016 at Lake Mohave and in 2017 at Lake Mead. Net radiation was no longer directly measured and had to be estimated from $\mathrm{Q}_{\mathrm{s}}$. Heat storage was estimated using the lake levels and average water profiles from preceding years. Vapor pressure difference was no longer measured and could not be used as confirmation of EC measurements. However, the estimates of available energy components in the years after the platforms were removed were based on 3 years of collected data and are considered adequate for energy balance purposes.

\section{Annual Estimates}

Annual estimates of evaporation at Lake Mead and Lake Mohave were calculated from January through December for each year for the period of record (figs. $16 A$ and $B$; tables 8 and 9). Annual evaporation estimates in this study represent the average of minimum probable evaporation estimates (as calculated directly from $\mathrm{Q}_{\mathrm{e}}$ measurements using equation 1) and maximum evaporation estimates (evaporation adjusted for forced closure of the energy balance equation). Forced closure of $\mathrm{Q}_{\mathrm{e}}$ is calculated by dividing annual $\mathrm{Q}_{\mathrm{e}}$ by the annual EBR. The annual percent difference between measured $\mathrm{Q}_{\mathrm{e}}$ and forced closed $\mathrm{Q}_{\mathrm{e}}$ is used as the forced closure adjustment for evaporation. Annual forced closure percent differences at Lake Mead ranged from -7 to 10 percent over the course of the study, with a period of record mean of 1.7 percent. Annual forced closure percent differences at Lake Mohave ranged from -2 to 56 percent over the course of the study, with a period of record mean of 24 percent. Maximum probable evaporation estimates are calculated by applying the annual forced closure percent differences to evaporation measurements.

Annual evaporation at Lake Mead was consistently greater than at Lake Mohave, primarily from $\mathrm{Q}_{\mathrm{V}}$ and sensibleheat differences (fig. 16C). Average annual evaporation at Lake Mead was $1,896 \mathrm{~mm}$, a 10 percent difference from the average annual evaporation at Lake Mohave of 1,718 mm (tables 8 and 9). Lake Mead has positive annual $\mathrm{Q}_{\mathrm{v}}$, meaning 
Table 8. Annual evaporation and summary statistics, Lake Mead, Nevada and Arizona, January 2011 through December 2018.

[Units: millimeters, $\mathrm{mm}$ ]

\begin{tabular}{cccc}
\hline Year & Evaporation, probable minimum & Evaporation, most probable & Evaporation, probable maximum \\
\hline 2011 & 1,788 & 1,840 & 1,892 \\
2012 & 1,798 & 1,884 & 1,970 \\
2013 & 1,717 & 1,743 & 1,769 \\
2014 & 1,846 & 1,878 & 1,911 \\
2015 & 1,908 & 1,952 & 1,996 \\
2016 & 1,912 & 1,988 & 2,064 \\
2017 & 1,935 & 1,963 & 1,991 \\
2018 & 1,891 & 1,916 & 1,942 \\
\hline & Period of record summary statistics & 1,942 \\
Mean & 1,849 & 1,896 & 88 \\
Standard deviation & 76 & 79 & 2,064 \\
Maximum & 1,935 & 1,988 & 1,769 \\
Minimum & 1,717 & 1,743 & \\
\hline
\end{tabular}

Table 9. Annual evaporation and summary statistics, Lake Mohave, Nevada and Arizona, January 2014 through December 2018.

[Units: millimeters, $\mathrm{mm}$ ]

\begin{tabular}{cccc}
\hline Year & Evaporation, probable minimum & Evaporation, most probable & Evaporation, probable maximum \\
\hline 2014 & 1,511 & 1,601 & 1,691 \\
2015 & 1,414 & 1,713 & 2,012 \\
2016 & 1,352 & 1,735 & 2,118 \\
2017 & 1,717 & 1,864 & 2,010 \\
2018 & 1,660 & 1,676 & 1,693 \\
\hline & Period of record summary statistics \\
\hline Mean & 1,531 & 1,718 & 1,905 \\
Standard deviation & 156 & 96 & 199 \\
Maximum & 1,717 & 1,864 & 2,118 \\
Minimum & 1,352 & 1,601 & 1,691 \\
\hline
\end{tabular}

more heat is added to the lake from inflows than is lost to outflows. Lake Mohave has negative annual $\mathrm{Q}_{\mathrm{v}}$, indicating a net downward flux of energy from the atmosphere to the lake.

\section{Comparison to Existing Rate Coefficients}

Lake Mead monthly evaporation coefficients for the 24MS study compared reasonably well to evaporation estimates determined in this study (fig. 17A). The 24MS monthly evaporation ranged from 21 percent more than to 24 percent less than the most probable estimates of EC mean monthly evaporation, with a mean difference of 4 percent and a standard deviation of 13 percent. The $24 \mathrm{MS}$ evaporation coefficients for Lake Mead are reasonable but overestimate evaporation during the peak summer months of July and August. The temporal trend in $24 \mathrm{MS}$ evaporation relative to the study evaporation indicates that the effects of heat storage were underestimated, particularly during the fall months when energy is still being released from the lake (Moreo and Swancar, 2013). Peak evaporation lagged peak $Q_{n}$ by approximately 2 months at Lake Mead and 3 months at Lake Mohave (figs. $7 C$ and $8 B$ ), and monthly evaporation estimates from this study are less variable than the 24MS estimates (fig. 17).

Lake Mohave monthly evaporation coefficients for the 24MS study did not compare as well to evaporation estimates determined in this study (fig. 17B). The 24MS monthly evaporation ranged from 67 percent greater to 31 percent less than the most probable estimates of EC mean monthly evaporation, with a mean difference of 20 percent and a standard deviation of 28 percent. The $24 \mathrm{MS}$ substantially overestimates evaporation from spring through summer at Lake Mohave. The difference in the seasonal patterns between the 24MS evaporation and this study indicates that the effects of $\mathrm{Q}_{\mathrm{v}}$ on evaporation at Lake Mohave were substantially underestimated. 
$A$

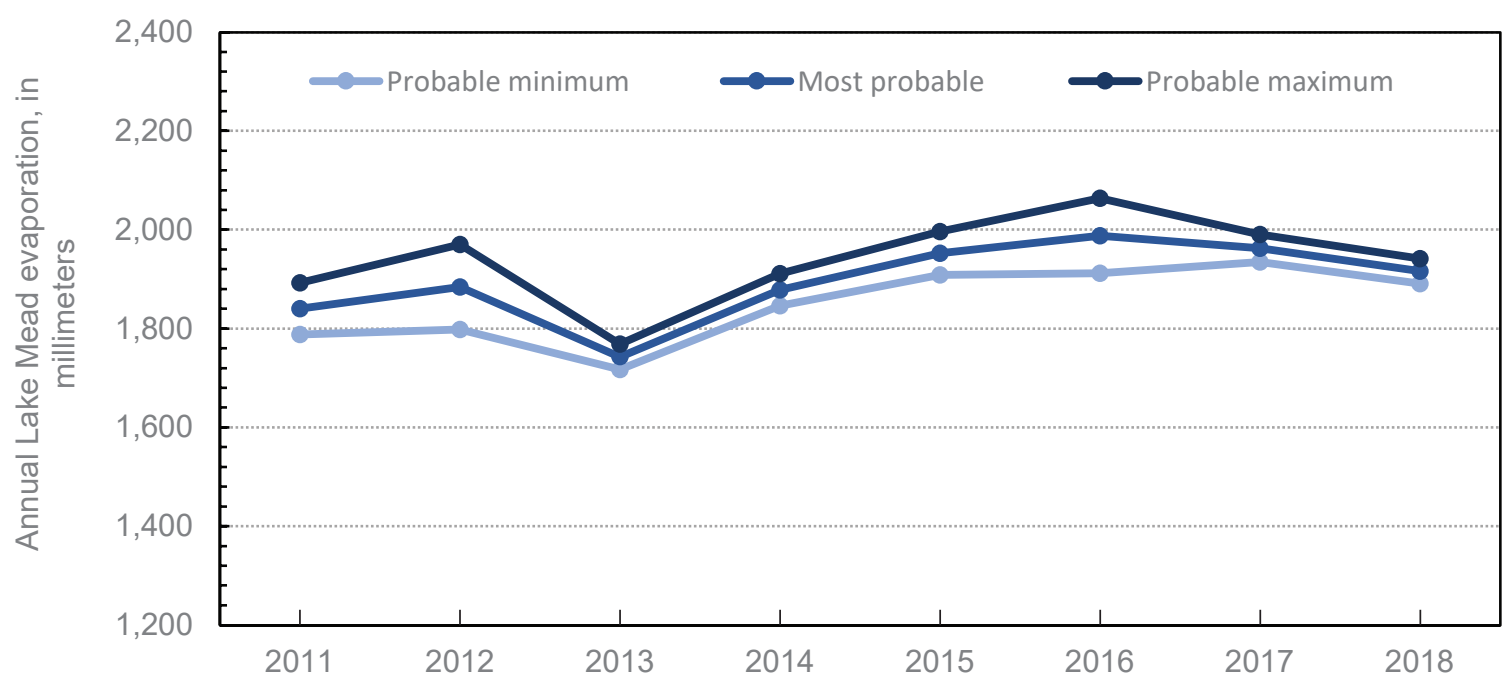

$B$

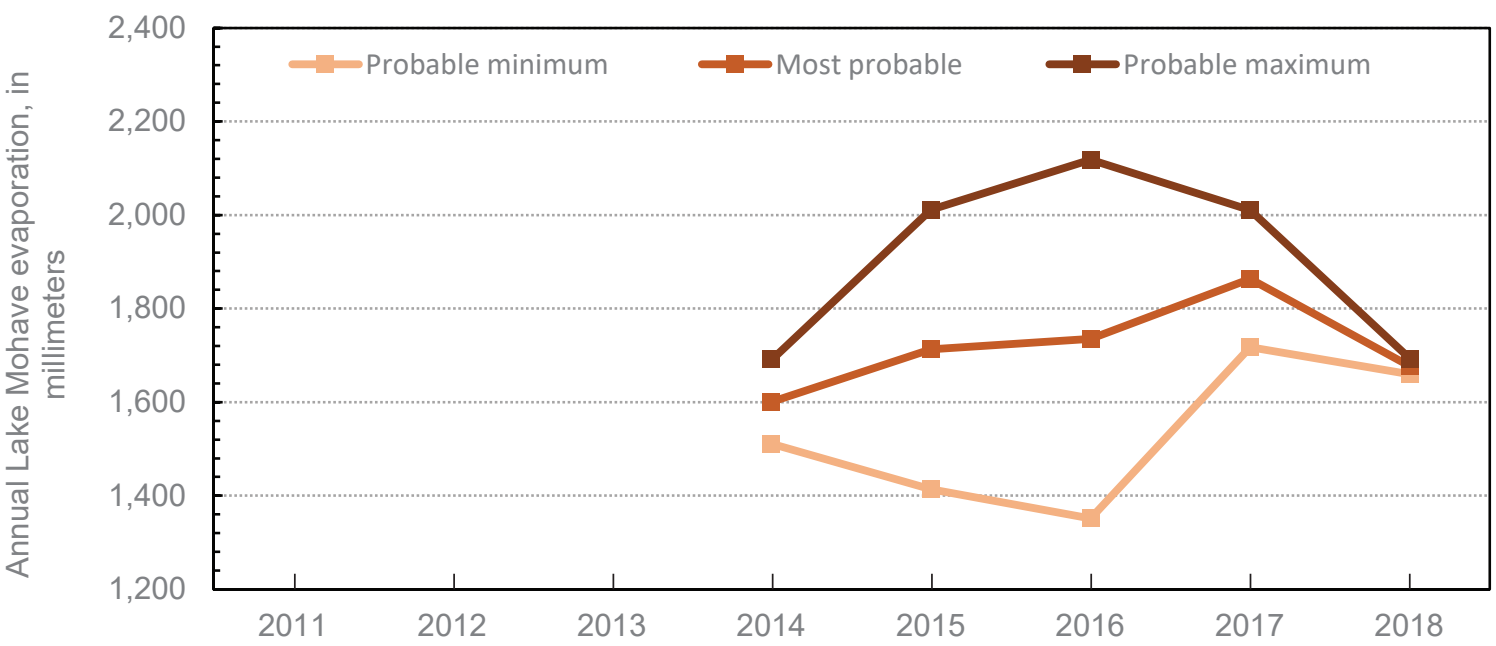

C

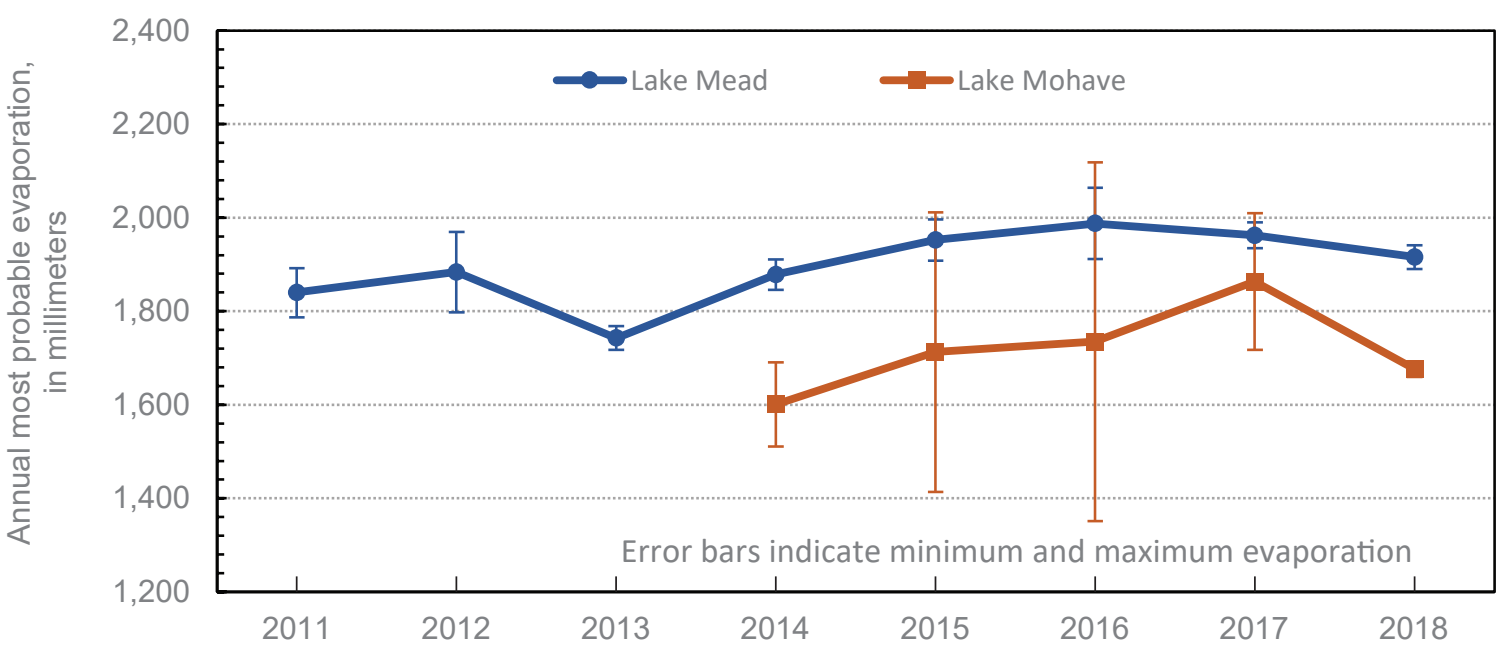

Figure 16. Probable minimum, most probable, and probable maximum annual evaporation at $A$, Lake Mead and $B$, Lake Mohave; and $C$, most probable annual evaporation at Lake Mead and Lake Mohave, Nevada and Arizona, May 2010 through April 2019. Error bars indicate the maximum, minimum, and most probable evaporation estimates in $C$. 

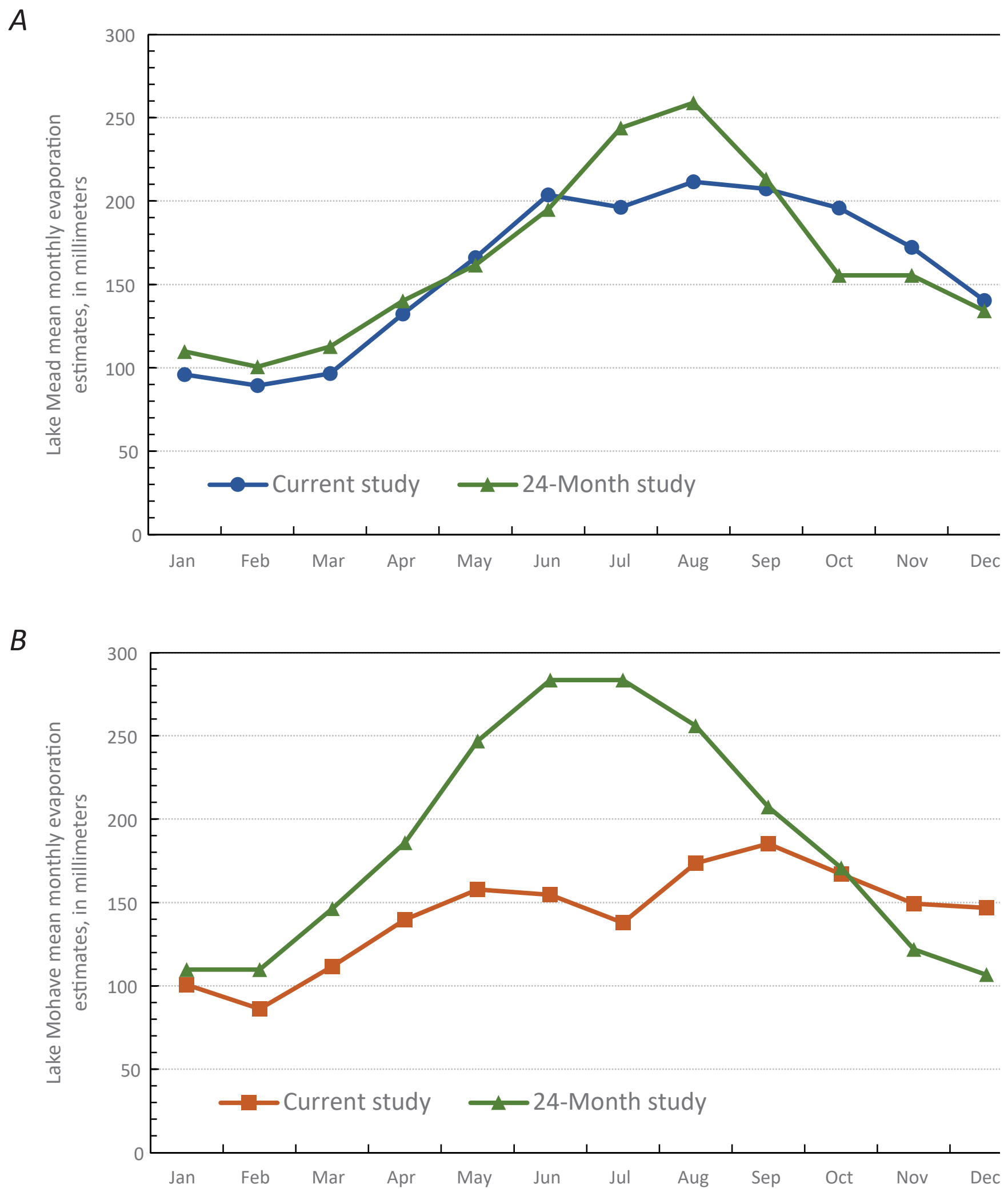

Figure 17. A, Lake Mead and B, Lake Mohave, Nevada and Arizona, mean monthly evaporation estimates for this study compared to 24-month study (24MS) evaporation coefficients, March 2013 through April 2019. 


\section{References Cited}

Allen, R.A., Pereira, L.S., Raes, D., and Smith, M., 1998, Crop evapotranspiration-Guidelines for computing crop water requirements-FAO irrigation and drainage paper 56: Rome, Italy, Food and Agricultural Organization of the United Nations, 300 p.

Anderson, E.R., and Pritchard, D.W., 1951, Physical limnology of Lake Mead: U.S. Navy Electronics Lab Report $258,153 \mathrm{p}$.

Baldocchi, D.D., 2003, Assessing the eddy covariance technique for evaluating carbon dioxide exchange rates of ecosystems - Past, present, and future: Global Change Biology, v. 9, no. 4, p. 479-492, https://doi.org/10.1046/ j.1365-2486.2003.00629.x.

Blanken, P.D., Rouse, W.R., and Schertzer, W.M., 2003, Enhancement of evaporation from a large northern lake by the entrainment of warm, dry air: Journal of Hydrometeorology, v. 4, no. 4, p. 680-693, https://doi.org/10.1175/1525-7541(2003)004\%3C0 680:EOEFAL\%3E2.0.CO;2.

Bowen, I.S., 1926, The ratio of heat losses by conduction and by evaporation from any water surface: Physical Review, v. 27, no. 6, p. 779-787, https://doi.org/10.1103/ PhysRev.27.779.

Brutsaert, W.H., 1982, Evaporation into the atmosphere: Boston, Mass., D. Reidel Publishing, 302 p., https://doi.org/ 10.1007/978-94-017-1497-6.

Bureau of Reclamation, 1955, Davis Dam and powerplantTechnical record of design and construction, Davis Dam project, constructed 1942-53: Denver, Colo., U.S. Department of the Interior, 414 p.

Bureau of Reclamation, 2007, Colorado River interim guidelines for lower basin shortages and coordinated operations for Lakes Powell and Mead: Final Environmental Impact Statement, accessed October 10, 2012, at https://www .usbr.gov/lc/region/programs/strategies/FEIS/index.html.

Campbell Scientific, Inc., 2008, EdiRe software for micrometeorological applications: Campbell Scientific, Inc, App. Note Code: 3C-R, 18 p., accessed March 22, 2021, at https:/s.campbellsci.com/documents/fr/technical-papers/ edire.pdf.

Campbell Scientific, Inc., 2010a, Instruction manual for KH2O krypton hygrometer, revision $2 / 10$, accessed December 23, 2010, at http://s.campbellsci.com/documents/ us/manuals/kh20.pdf.
Campbell Scientific, Inc., 2010b, Instruction manual for CSAT3 three-dimensional sonic anemometer, revision 6/10, accessed September 28, 2011, at http://s.campbellsci.com/ documents/us/manuals/csat3.pdf.

Campbell Scientific, Inc., 2010c, Instruction manual for CNR2 net radiometer, revision 5/10, accessed October 10, 2012, at http://s.campbellsci.com/documents/us/manuals/cnr2.pdf.

Campbell Scientific, Inc., 2011, Instruction manual for CNR1 net radiometer, revision 5/11, accessed November 16, 2012, at http://s.campbellsci.com/documents/us/manuals/cnr1.pdf.

Campbell Scientific, Inc., 2017, Instruction manual for HC2S3 temperature and relative humidity probe, revision $4 / 17$, accessed November 13, 2020, at https://s.campbellsci.com/ documents/ca/manuals/hc2-s3-1_man.pdf.

Campbell Scientific, Inc., 2018a, Operator's manual for CR3000 micrologger revision 2/18, accessed November 19, 2020, at https://s.campbellsci.com/documents/us/manuals/ cr3000.pdf.

Campbell Scientific, Inc., 2018b, Product manual for CS300 and CS301 pyranometers, revision 9/18, accessed November 13, 2020, at https://s.campbellsci.com/ documents/us/manuals/cs300.pdf.

Campbell Scientific, Inc., 2019, Product manual for NR-LITE2 net radiometer, revision 6/19, accessed November 19, 2020, at https://s.campbellsci.com/ documents/us/manuals/nr-lite2.pdf.

Falge, E., Baldocchi, D., Olson, R., Anthoni, P., Aubinet, M., Bernhofer, C., Burba, G., Ceulemans, R., Clement, R., Dolman, H., Granier, A., Gross, P., Grünwald, T., Hollinger, D., Jensen, N.-O., Katul, G., Keronen, P., Kowalski, A., Ta Lai, C., Law, B.E., Meyers, T., Moncrieff, J., Moors, E., William Munger, J., Pilegaard, K., Rannik, Ü., Rebmann, C., Suyker, A., Tenhunen, J., Tu, K., Verma, S., Vesala, T., Wilson, K., and Wofsy, S., 2001, Gap filling strategies for long term energy flux data sets: Agricultural and Forest Meteorology, v. 107, no. 1, p. 71-77, https://doi.org/ 10.1016/S0168-1923(00)00235-5.

Ferrari, R.L., 2008, 2001 Lake Mead sedimentation surveyBureau of Reclamation report: Denver, Colo., Technical Service Center, 212 p.

Finch, J.W., and Hall, R.L., 2005, Evaporation from lakes, chap. 44 of Anderson, M.G., and McDonnell, J.J., eds., Encyclopedia of hydrological sciences: John Wiley \& Co, Ltd., 12 p., https://doi.org/10.1002/0470848944.hsa047.

Foken, T., 2008, Micrometeorology: Berlin, Heidelberg, Springer, $306 \mathrm{p}$. 
Foken, T., Leuning, R., Oncley, S., Mauder, M., and Aubinet, M., 2012, Corrections and data quality control, chap. 4 of Aubinet, M., Vesala, T., and Papale, D., eds., Eddy covariance-A practical field guide to measurement and data analysis: Dordrecht-Heidelberg-London-New York, Springer, p. 85-131, https://doi.org/10.1007/978-94-0072351-1 4.

Granger, R.J., and Hedstrom, N., 2011, Modelling hourly rates of evaporation from small lakes: Hydrology and Earth System Sciences, v. 15, no. 1, p. 267-277, https:/doi.org/ 10.5194/hess-15-267-2011.

Harbeck, G.E., Jr., Kohler, M.A., Koberg, G.E., and others, 1958, Water-loss investigations_Lake Mead studies: U.S. Geological Survey Professional Paper 298, 100 p., https ://pubs.er.usgs.gov/publication/pp298.

Højstrup, J., 1993, A statistical data screening procedure: Measurement Science \& Technology, v. 4, no. 2, p. 153-157, https://doi.org/10.1088/0957-0233/4/2/003.

Holdren, G.C., and Turner, K., 2010, Characteristics of Lake Mead, Arizona-Nevada: Lake and Reservoir Management, v. 26, no. 4, p. 230-239, accessed November 24, 2020, at https://doi.org/10.1080/07438141.2010.540699.

Kaimal, J.C., and Finnigan, J.J., 1994, Atmospheric boundary layer flows, their structure and measurement: New York, N.Y., Oxford University Press, 289 p., https://doi.org/ 10.1093/oso/9780195062397.001.0001.

Law, B.E., Boden, T.A., and the AmeriFlux Steering Committee, 2005, Ameriflux site evaluation and recommendations for network enhancement, December 2005: Ameriflux, $27 \mathrm{p}$.

Leuning, R., van Gorsel, E., Massman, W.J., and Isaac, P.R., 2012, Reflections on the surface energy imbalance problem: Agricultural and Forest Meteorology, v. 156, p. 65-74, https://doi.org/10.1016/j.agrformet.2011.12.002.

Liu, H., Zhang, Y., Liu, S., Jiang, H., Sheng, L., and Williams, Q.L., 2009, Eddy covariance measurements of surface energy budget and evaporation in a cool season over southern open water in Mississippi: Journal of Geophysical Research, v. 114, no. D4, 13 p., https://doi.org/10.1029/ 2008JD010891.

Moore, C.J., 1986, Frequency response corrections for eddy correlation systems: Boundary-Layer Meteorology, v. 37, no. 1-2, p. 17-35, https://doi.org/10.1007/BF00122754.

Moreo, M.T., 2015, Evaporation data from Lake Mead and Lake Mohave, Nevada and Arizona, March 2010 through April 2015: U.S. Geological Survey data release, https://doi.org/10.5066/F79C6VG3.
Moreo, M.T., 2018, Meteorological data for Lake Mead and Lake Mohave, Nevada and Arizona, April 2013 to April 2017: U.S. Geological Survey data release, https://doi.org/10.5066/F7G44PJ9.

Moreo, M.T., and Swancar, A., 2013, Evaporation from Lake Mead, Nevada and Arizona, March 2010 through February 2012: U.S. Geological Survey Scientific Investigations Report 2013-5229, 40 p., https:/doi.org/ $10.3133 / \operatorname{sir} 20135229$.

National Weather Service, 2013, The climate of Las Vegas, Nevada: National Weather Service Publication, updated November 6, 2013, 153 p., https://www.wrh.noaa.gov/vef/ climate/LasVegasClimateBook/Mean\%20Average $\% 20 \mathrm{Wi}$ nd $\% 20$ Speed $\% 20$ And $\% 20$ Windiest $\% 20$ Months.pdf.

National Park Service, 2020, Overview of Lake Mohave webpage, accessed October 29, 2020, at https://www.nps.gov/ lake/learn/nature/overview-of-lake-mohave.htm.

NovaLynx, 2007, Instruction manual for model 260-2510 standard rain and snow gauge, accessed February 18, 2020, at https:/novalynx.com/manuals/260-2510-manual.pdf.

Ohmart, R.D., Anderson, B.W., and Hunter, W.C., 1988, The ecology of the lower Colorado River from Davis Dam to the Mexico-United States International Boundary-a community profile: U.S. Fish and Wildlife Service, Biology Report 85 (7.19), 296 p., https://apps.dtic.mil/sti/pdfs/ ADA323043.pdf.

Omar, M.H., and El-Bakry, M.M., 1981, Estimation of evaporation from the lake of the Aswan High Dam (Lake Nasser) based on measurements over the lake: Agricultural Meteorology, v. 23, p. 293-308, https://doi.org/10.1016/ 0002-1571(81)90115-1.

Rosen, M.R., Turner, K., Goodbred, S.L., and Miller, J.M., eds., 2012, A synthesis of aquatic science for management of Lakes Mead and Mohave, U.S. Geological Survey Circular 1381, 162 p., https://doi.org/10.3133/cir1381.

Rosenberry, D.O., Winter, T.C., Buso, D.C., and Likens, G.E., 2007, Comparison of 15 evaporation methods applied to a small mountain lake in the northeastern USA-Amsterdam, The Netherlands: Journal of Hydrology (Amsterdam), v. 340, no. 3-4, p. 149-166, https://doi.org/10.1016/j .jhydrol.2007.03.018.

Sacks, L.A., Lee, T.M., and Radell, M.J., 1994, Comparison of energy-budget evaporation losses from two morphometrically different Florida seepage lakes-Amsterdam, The Netherlands: Journal of Hydrology (Amsterdam), v. 156, no. 1-4, p. 311-334, https://doi.org/10.1016/00221694(94)90083-3. 
Saur, J.F.T., and Anderson, E.R., 1956, The heat budget of a body of water of varying volume: Limnology and Oceanography, v. 1, no. 4, p. 247-251, https://doi.org/ 10.4319/1o.1956.1.4.0247.

Schotanus, P., Nieuwstadt, F.T.M., and de Bruin, H.A.R., 1983, Temperature measurement with a sonic anemometer and its application to heat and moisture fluxes: BoundaryLayer Meteorology, v. 26, no. 1, p. 81-93, https://doi.org/ 10.1007/BF00164332.

Smith, W.O., Vetter, C.P., Cummings, G.B., and others, 1960, Comprehensive survey of sedimentation in Lake Mead, 1948-49: U.S. Geological Survey Professional Paper 295, 254 p., https://doi.org/10.3133/pp295.

Stannard, D.I., Gannett, M.W., Polette, D.J., Cameron, J.M., Waibel, M.S., and Spears, J.M., 2013, Evapotranspiration from marsh and open-water sites at Upper Klamath Lake, Oregon, 2008-2010: U.S Geological Survey Scientific Investigations Report 2013-5014, 65 p., https://doi.org/ 10.3133/sir20135014.

Stull, R.B., 1988, Mean boundary layer characteristics, in Stull, R.B., ed., An introduction to boundary layer meteorology-Atmospheric Sciences Library v. 13: Dordrecht, The Netherlands, Springer, p. 1-27, https://doi.org/10.1007/978-94-009-3027-8_1.

Swinbank, W.C., 1951, The measurement of vertical transfer of heat and water vapor by eddies in the lower atmosphere: Journal of Meteorology, v. 8, no. 3, p. 135-145, https://doi.org/10.1175/1520-0469(1951)008\%3C0 135:TMOVTO\%3E2.0.CO;2.

Tanner, B.D., and Greene, J.P., 1989, Measurement of sensible heat and water-vapor fluxes using eddy-correlation methods - Final report prepared for U.S. Army Dugway Proving Grounds-Dugway: Utah, U.S. Army, 17 p.

Thomas, H.E., 1954, First fourteen years of Lake Mead: U.S. Geological Survey Circular 346, 27 p., https://doi.org/ $10.3133 /$ cir346.

Tighi, S., and Callejo, R., 2011, Lake Mead area and capacity tables: Bureau of Reclamation, Lower Colorado Region, Boulder Canyon Operations Office, River Operations Group report, 149 p., https://www.usbr.gov/lc/region/g4000/LM_ AreaCapacityTables2009.pdf.

Turner, K., Rosen, M.R., Holdren, G.C., Goodbred, S.L., and Twichell, D.C., 2012, Environmental setting of Lake Mead National Recreation Area, chap. 2 of Rosen, M.R., Turner, K., Goodbred, S.L., and Miller, J.M., eds., 2012, A synthesis of aquatic science for management of Lakes Mead and Mohave: U.S. Geological Survey Circular 1381, 162 p., https://doi.org/10.3133/cir1381.
U.S. Department of Commerce, 1953, Wind patterns over lower Lake Mead: U.S. Department of Commerce, Weather Bureau, Hydrologic Services Division Technical Paper No. 22, 40 p., https://www.weather.gov/media/owp/oh/hdsc/ docs/TP22.pdf.

U.S. Geological Survey, 1954, Water-loss investigations: Lake Hefner studies, technical report: U.S. Geological Survey Professional Paper 269, 158 p., https://doi.org/10.3133/p p269.

U.S. Geological Survey, 2021, National Water Information System: U.S. Geological Survey web interface, accessed January 20, 2021, at https://doi.org/10.5066/F7P55KJN.

Veley, R.J., and Moran, M.J., 2012, Evaluating lake stratification and temporal trends by using near-continuous water-quality data from automated profiling systems for water years 2005-09, Lake Mead, Arizona and Nevada: U.S. Geological Survey Scientific Investigations Report 2012-5080, 25 p., https://doi.org/10.3133/sir20125080.

Voichick, N., and Wright, S.A., 2007, Water-temperature data for the Colorado River and tributaries between Glen Canyon Dam and Spencer Canyon, northern Arizona, 1988-2005: U.S. Geological Survey Data Series 251, 28 p., https://doi.org/10.3133/ds251.

Webb, E.K., Pearman, G.I., and Leuning, R., 1980, Correction of flux measurements for density effects due to heat and water vapour transfer: Quarterly Journal of the Royal Meteorological Society, v. 106, no. 447, p. 85-100, https://doi.org/10.1002/qj.49710644707.

Westenburg, C.L., DeMeo, G.A., and Tanko, D.J., 2006, Evaporation from Lake Mead, Arizona and Nevada, 1997-99: U.S. Geological Survey Scientific Investigations Report 2006-5252, 24 p., https://doi.org/10.3133/ $\operatorname{sir} 20065252$.

Wilson, K., Goldstein, A., Falge, E., Aubinet, M., Baldocchi, D., Berbigier, P., Bernhofer, C., Ceulemans, R., Dolman, H., Field, C., Grelle, A., Ibrom, A., Law, B., Kowalski, A., Meyers, T., Moncrieff, J., Monson, R., Oechel, W., Tenhunen, J., Valentini, R., and Verma, S., 2002, Energy balance closure at FLUXNET sites: Agricultural and Forest Meteorology, v. 113, no. 1-4, p. 223-243, https://doi.org/ 10.1016/S0168-1923(02)00109-0.

Wright, S.A., Anderson, C.R., and Voichick, N., 2009, A simplified water temperature model for the Colorado River below Glen Canyon Dam: River Research and Applications, v. 25 , no. 6 , p. 675-686, https://doi.org/10.1002/rra.1179. 
For more information concerning the research in this report, contact the

Nevada Water Science Center

U.S. Geological Survey

2730 N. Deer Run Road

Carson City, Nevada 89701

https://www.usgs.gov/centers/nv-water

Publishing support provided by the U.S. Geological Survey

Science Publishing Network, Sacramento Publishing Service Center 


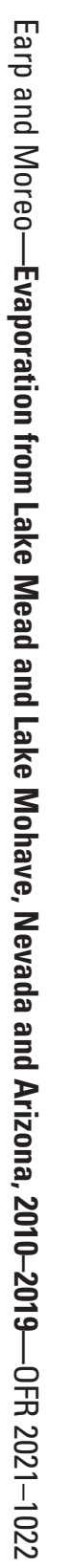

